UNIVERSIDADE DE BRASÍLIA

FACULDADE DE TECNOLOGIA DEPARTAMENTO DE ENGENHARIA ELÉTRICA

\title{
APLICATIVO PARA A AVALIAÇÃO MULTICRITÉRIO DE PROJETOS DE GERAÇÃO PARA ATENDIMENTO A COMUNIDADES ISOLADAS
}

PEDRO GEORGE PRESCOTT FERRAZ

ORIENTADOR: MAURO MOURA SEVERINO

TRABALHO DE CONCLUSÃO DE CURSO EM ENGENHARIA ELÉTRICA

$$
\text { BRASÍLIA/DF: JULHO - } 2008
$$


UNIVERSIDADE DE BRASÍLIA

FACULDADE DE TECNOLOGIA

DEPARTAMENTO DE ENGENHARIA ELÉTRICA

\author{
APLICATIVO PARA A AVALIAÇÃO MULTICRITÉRIO DE \\ PROJETOS DE GERAÇÃO PARA ATENDIMENTO A \\ COMUNIDADES ISOLADAS
}

PEDRO GEORGE PRESCOTT FERRAZ

DISSERTAÇÃO SUBMETIDA AO DEPARTAMENTO DE ENGENHARIA ELÉTRICA DA FACULDADE DE TECNOLOGIA DA UNIVERSIDADE DE BRASÍLIA COMO PARTE DOS REQUISITOS NECESSÁRIOS PARA A OBTENÇÃO DO DIPLOMA EM ENGENHARIA ELÉTRICA.

APROVADA POR:

Prof. Mauro Moura Severino, Mestre (ENE-UnB)

(Orientador)

Prof. Marco Aurélio Gonçalves de Oliveira, Dr. (ENE-UnB)

(Examinador Interno)

Prof. Ivan Marques de Toledo Camargo, Dr. (ENE-UnB)

(Examinador Interno)

BRASÍLIA/DF, 07 DE JULHO DE 2008 
FICHA CATALOGRÁFICA

FERRAZ, PEDRO GEORGE PRESCOTT

Aplicativo para a Avaliação Multicritério de Projetos de Geração para atendimento a Comunidades Isoladas [Distrito Federal] 2008.

Trabalho de Conclusão de Curso - Universidade de Brasília. Faculdade de Tecnologia. Departamento de Engenharia Elétrica.

1.Fornecimento de energia elétrica a comunidades isoladas 2.Abordagens dos impactos

3.Metodologia 4.Aplicativo

$\begin{array}{ll}\text { I. ENE/FT/UnB II. Título (série) } & \end{array}$

\section{REFERÊNCIA BIBLIOGRÁFICA}

\section{CESSÃO DE DIREITOS}

AUTOR: Pedro George Prescott Ferraz.

TÍTULO: Aplicativo para a Avaliação Multicritério de Projetos de Geração para atendimento a Comunidades Isoladas.

GRAU: Engenheiro Eletricista

ANO: 2008

É concedida à Universidade de Brasília permissão para reproduzir cópias deste trabalho de conclusão de curso e para emprestar ou vender tais cópias somente para propósitos acadêmicos e científicos. O autor reserva outros direitos de publicação e nenhuma parte desse trabalho de conclusão de curso pode ser reproduzida sem autorização por escrito do autor.

Pedro George Prescott Ferraz

Email: pgprescott@gmail.com

Apart. 204, bloco K, quadra 110, bairro Asa Norte, Brasília.

70.753-110 Brasília - DF - Brasil. 


\section{AGRADECIMENTOS}

Agradeço ao meu orientador por me ajudar, de forma decisiva, a delinear as soluções encontradas neste trabalho, uma pessoa de grande caráter e experiência, cuja convivência foi muito gratificante para mim.

Agradeço a minha família, principalmente minha mãe e meu pai, pelo suporte dado, sem os quais certamente não poderia ter chegado nesta etapa da vida.

Agradeço minha avó, por estar sempre me apoiando e possibilitando muitas das minhas conquistas até aqui.

Em especial, agradeço mia tia, Elianne Prescott, por sua dedicação e apoio, que foram essenciais para o fechamento deste trabalho, me ajudando na revisão e organização. 


\section{RESUMO}

A geração de energia elétrica, principalmente em comunidades isoladas no Brasil, provoca grandes impactos sociais para seus moradores. Os impactos sociais associados à crescente preocupação mundial com os impactos ambientais, que incluem a poluição e o aquecimento global, fazem frente ao aspecto econômico dos projetos de geração. No entanto, não são disponibilizadas, de forma geral, formas objetivas e sistemáticas de comparação entres estes aspectos ambientais, sociais e econômicos na escolha ou análise dos projetos de geração.

Este trabalho desenvolve uma metodologia e um aplicativo multicritérios para avaliação e comparação de projetos de geração aplicados, especificamente, a comunidades isoladas. A metodologia criada tenta englobar os aspectos considerados pertinentes no atendimento a comunidades isoladas, envolvendo aspectos ambientais, sociais, econômicos e técnicos. 


\section{Sumário}

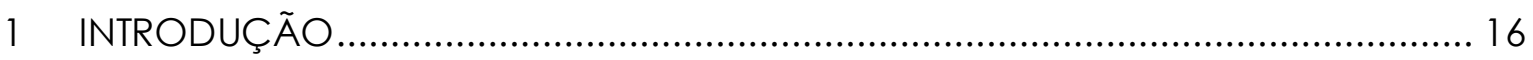

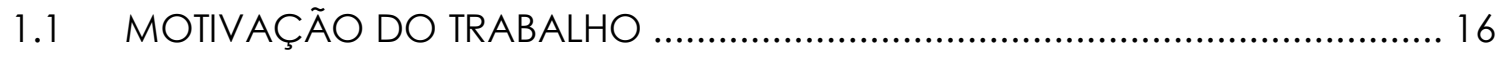

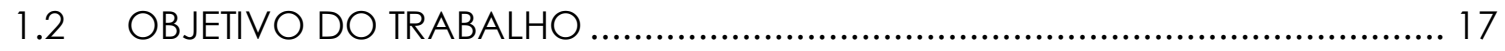

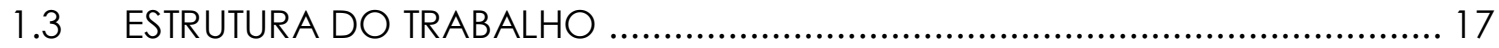

2 FORNECIMENTO DE ENERGIA ELÉTRICA A COMUNIDADES ISOLADAS E SEUS

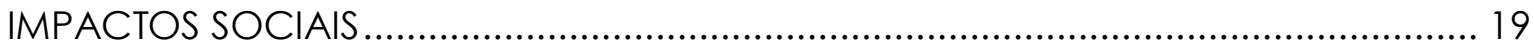

2.1 A PROBLEMÁTICA DO FORNECIMENTO DE ENERGIA ELÉTRICA .................. 19

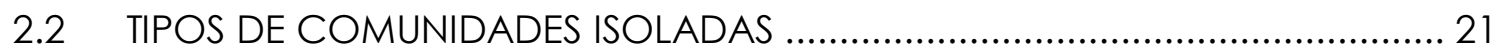

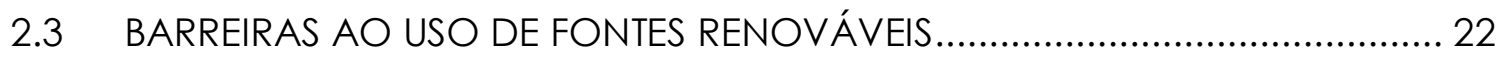

2.4 A IMPORTÂNCIA DO ATENDIMENTO ENERGÉTICO DAS COMUNIDADES

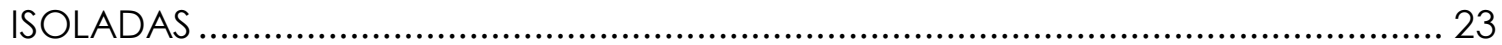

2.5 INCENTIVOS DO ESTADO À GERAÇÃO EM COMUNIDADES ISOLADAS ...... 24

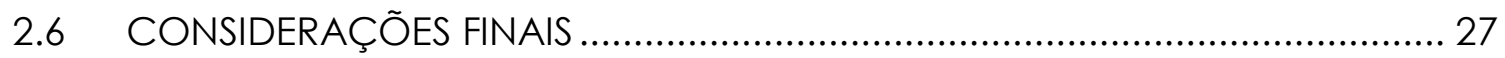

3 IMPACTOS DA GERAÇÃO DE ENERGIA ELÉTRICA E AS SUAS ABORDAGENS:

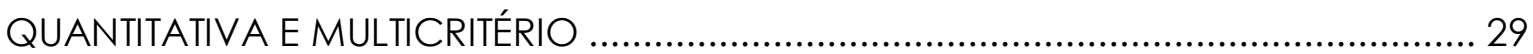

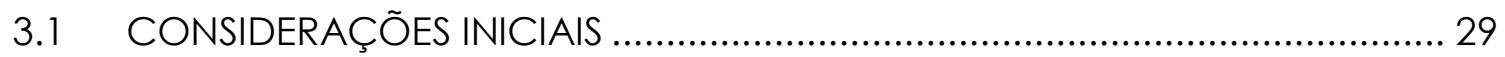

3.2 INTER-RELAÇÕES DAS ATIVIDADES ENERGÉTICAS ...................................... 31

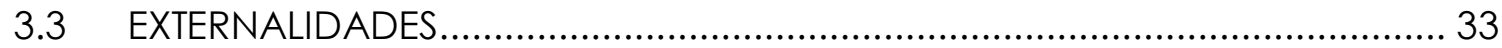

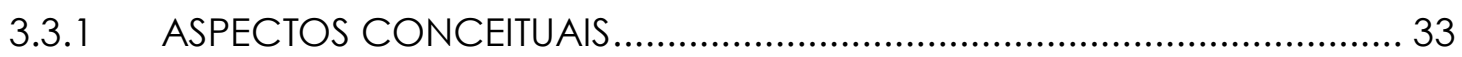

3.3.2 EXTERNALIDADES E INEFICIÊNCIA DO MERCADO ............................... 34

3.3.2.2 EXTERNALIDADES NO CONSUMO ..................................................... 37

3.3.3 SOLUÇÕES PARA AS EXTERNALIDADES ................................................. 39

3.3.3.1 SOLUÇÕES PRIVADAS PARA AS EXTERNALIDADES .............................. 40

3.3.3.2 SOLUÇÕES PÚBLICAS PARA AS EXTERNALIDADES ................................ 41

3.3.3.3 CONSIDERAÇÕES FINAIS SOBRE AS EXTERNALIDADES ….................... 44

3.4 TIPOS DE ABORDAGENS DOS IMPACTOS SOCIAIS E AMBIENTAIS................ 45

3.5 ABORDAGEM QUANTITATIVA DOS IMPACTOS EXTERNOS DA GERAÇÃO -

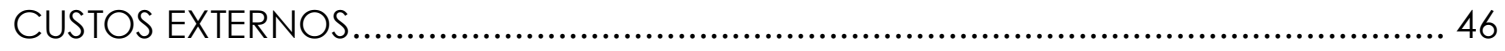

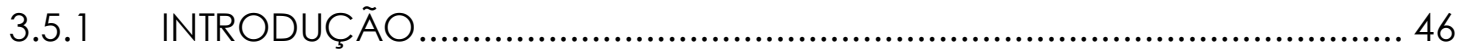

3.5.2 PROPÓSITOS DE QUANTIFICAR OS CUSTOS EXTERNOS ......................... 46 
3.5.3 BREVE HISTÓRICO DO ESTUDO DOS CUSTOS EXTERNOS ...................... 48

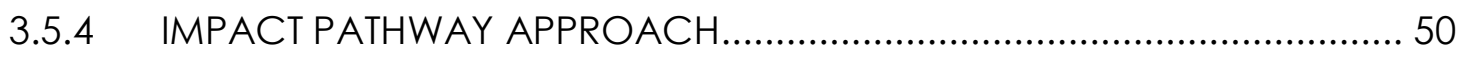

3.5.5 TIPOS IMPACTOS DA GERAÇÃO DE ENERGIA ..................................... 52

3.5.6 CONTRIBUIÇÃO DOS ESTUDOS DOS CUSTOS EXTERNOS....................... 53

3.6 ABORDAGEM MULTICRITÉRIO DOS IMPACTOS DA GERAÇÃO.................... 55

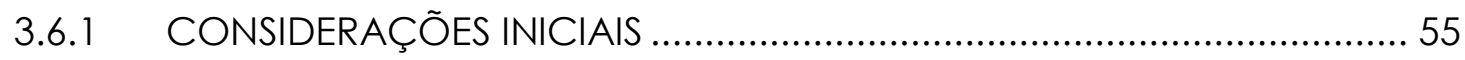

3.6.2 HISTÓRICO E ESTRUTURA DA ANÁLISE MULTICRITÉRIO .......................... 56

3.6.3 PROCEDIMENTOS DA ANÁLISE MULTICRITÉRIO ................................... 59

3.6.4 FORMAS DE ELEGER E AGRUPAR PREFERÊNCIAS .............................. 59

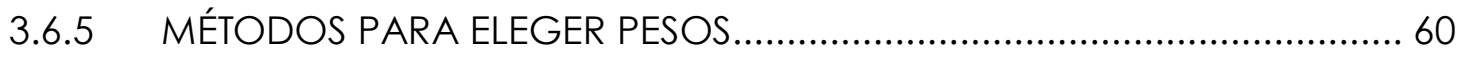

3.6.6 COMPARAÇÃO ENTRE OS MÉTODOS MULTICRÍTERIOS ......................... 63

3.6.7 CONSIDERAÇÕES FINAIS SOBRE MÉTODOS MULTICRITÉRIOS................ 64

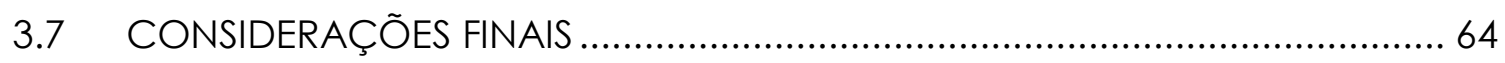

4 METODOLOGIA MULTICRITÉRIO APLICADA ÀS COMUNIDADES ISOLADAS ....... 66

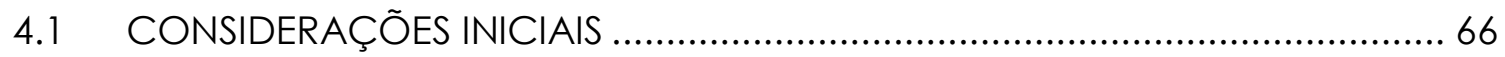

4.2 ETAPAS INICIAIS PARA A CRIAÇÃO DA AVALIAÇÃO MULTICRITÉRIO ......... 67

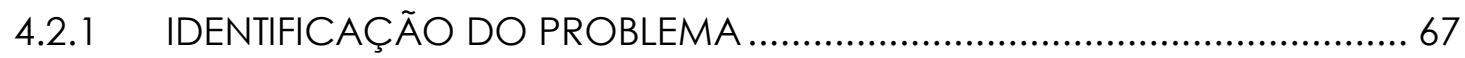

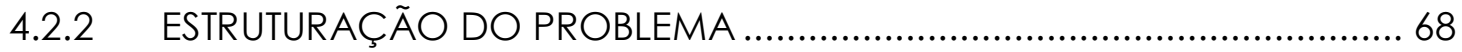

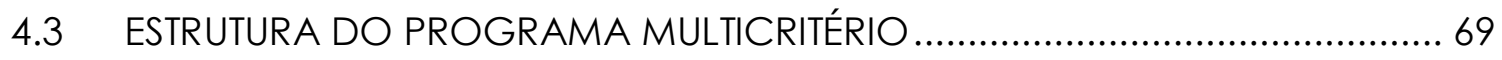

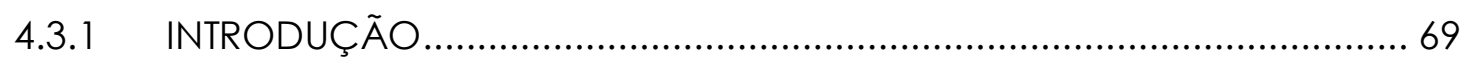

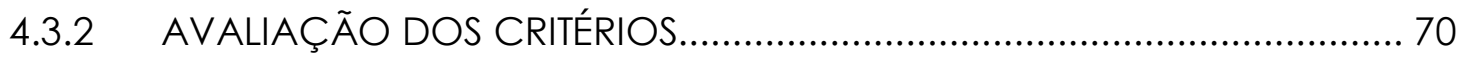

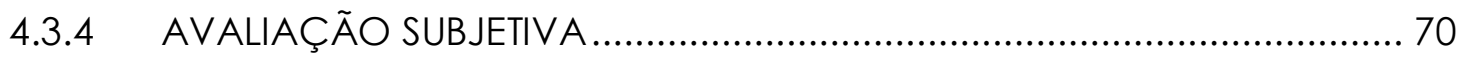

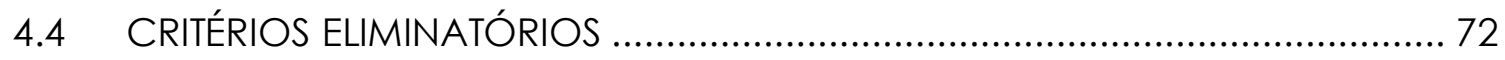

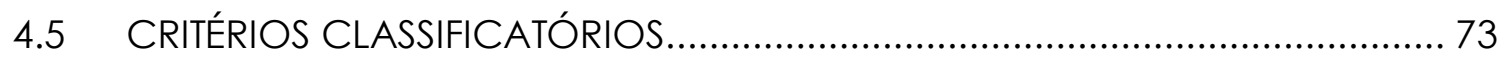

4.5.1 CRITÉRIOS ECONÔMICOS ...................................................................... 73

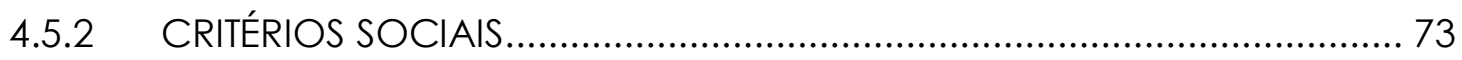

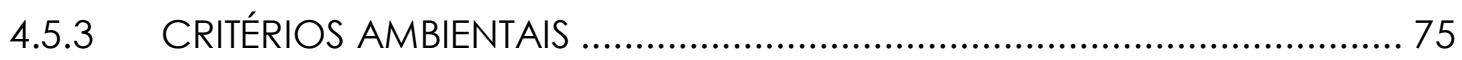

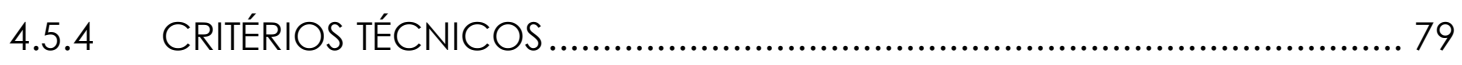

4.6 ALTERNATIVAS DE PROJETOS DE GERAÇÃO ................................................ 80

4.7 FORMAS DE ELEGER OS PESOS DOS CRITÉRIOS ........................................ 81

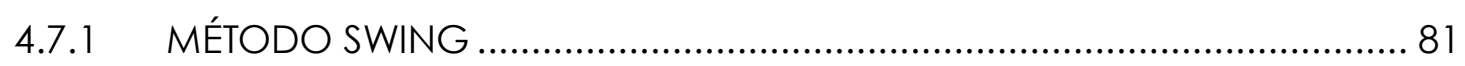

4.7.2 MÉTODO ANALITIC HIERARCHY PROCESS (AHP) ................................ 82 
4.8 ETAPAS DO AVALIADOR/ESPECIALISTA SEGUIDAS NO APLICATIVO MULTICRITÉRIO.

4.9 ETAPAS DA INSTITUIÇÃO RESPONSÁVEL POR REALIZAR A AVALIAÇÃO MULTICRITÉRIO.

4.9.1 DEFINIR OS CRITÉRIOS ELIMINATÓRIOS 89

4.9.2 ORGANIZAR PROPOSTAS DE PROJETOS DE GERAÇÃO 89

4.9.3 SUBMETER OS QUESTIONÁRIOS AOS AVALIADORES /ESPECIALISTAS ... 89

4.9.4 REUNIR OS QUESTIONÁRIOS RESPONDIDOS E LANÇAR A CLASSIFICAÇÃO RESULTANTE 90

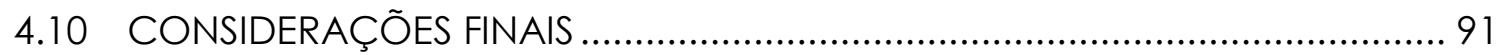

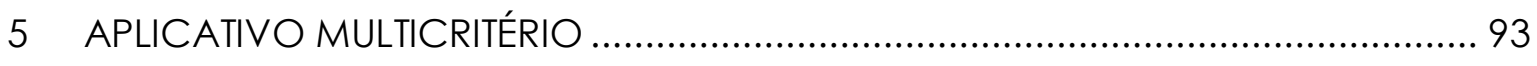

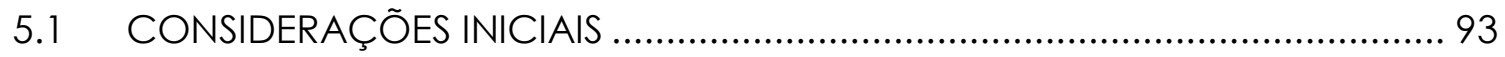

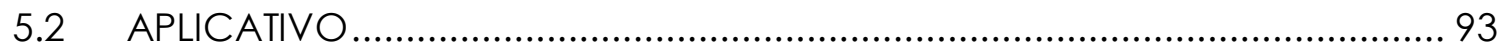

5.2.1 INTRODUÇÃO E OBJETIVO DO APLICATIVO ...................................... 93

5.2.2 ASPECTOS CONSTRUTIVOS DO APLICATIVO ....................................... 94

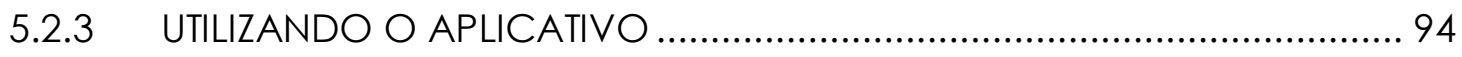

5.3 EXEMPLO DE APLICAÇÃO: AVALIAÇÃO DE OITO ALTERNATIVAS

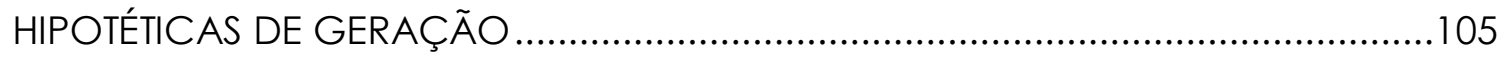

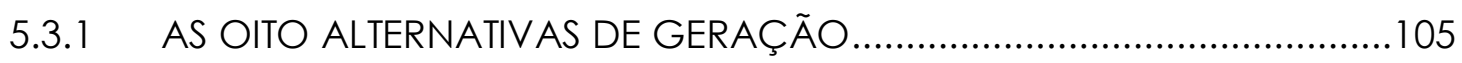

5.3.2 ELEGENDO PRIORIDADES DOS ONZE CRITÉRIOS ................................109

5.3.3 RESULTADOS DA AVALIAÇÃO DAS OITO ALTERNATIVAS ......................110

5.3.4 SENSIBILIDADE DOS RESULTADOS AOS PESOS ATRIBUÍDOS AOS CRITÉRIOS

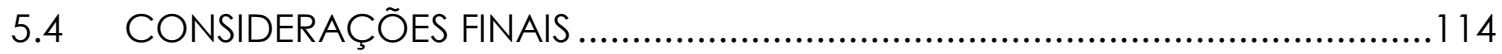

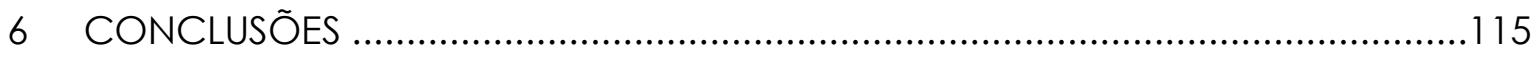

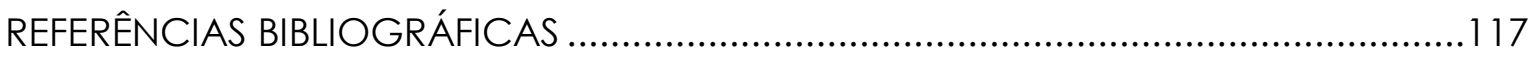




\section{ÍNDICE DE FIGURAS E ILUSTRAÇÕES}

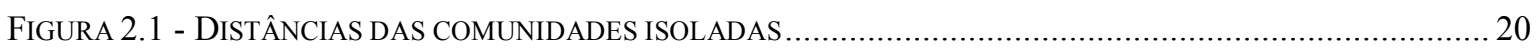

FIGURA 3.1 - DiAGRAMA COM QUESTÕES INTER-RELACIONADAS A ENERGIA. ............................................. 32

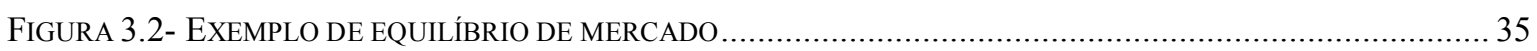

FIGURA 3.5- EXEMPLO DE TAXA PIGOUVIANA E COMERCIALIZAÇÃO DE PERMISSÕES........................................ 44

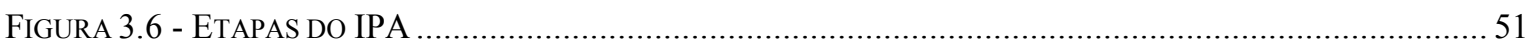

FIGURA 3.7 - CURVAS ILUSTRATIVAS DE OFERTA E DEMANDA DE POLUENTES............................................... 54

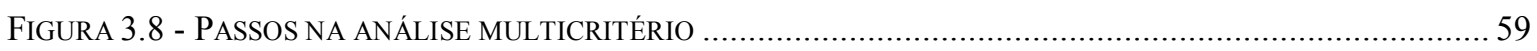

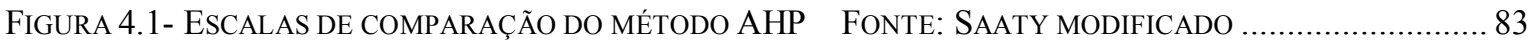

Figura 4.2 - Matriz de Comparações, método AHP. Fonte: APlicativo deSEnVolvido ................. 84

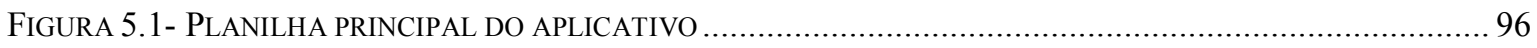

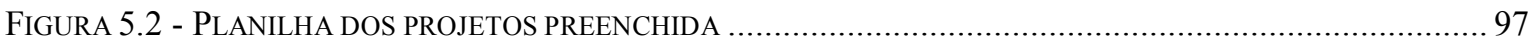

Figura 5.3- Planilha ClassificaÇão dos Critérios, elegendo Pesos Para os CRItÉRIOS ....................... 98

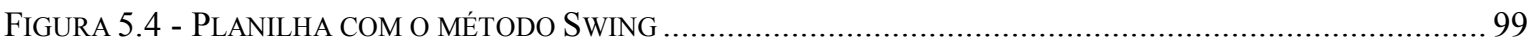

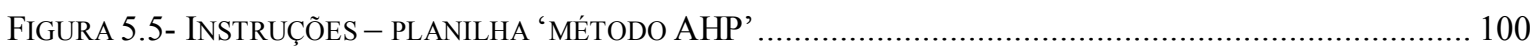

FIGURA 5.6 - MATRIZ DE COMPARAÇÕES - PLANILHA 'MÉTODO AHP' ......................................................... 100

FigURA 5.7- LEGENDA E TABELA COM A ESCALA DAS DOS VALORES DE COMPARAÇÃO - PLANILHA 'MÉTODO

AHP' 101 


\section{ÍNDICE DE TABELAS}

TABELA 3.1 - LISTA DE POLUENTES E SEUS IMPACTOS À SAÚDE.

TABela 3.2 - Comparação entre os métodos baseada na AVAliaÇão do EXternE-Pol (ANÁlise MULTICRITÉRIO)

TABela 4.1 - PAdRÃo DE AVALIAÇÃo dos CRITÉrios SUbJETIVOS. .72

TABELA 4.3 - SUGESTÃo PARA AVALIAÇ̃̃o DA POLUIÇÃO AMBIENTAL EM FUNÇÃO DA AO COMBUSTÍVEL....... 76

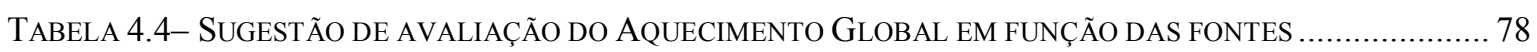

TABELA 4.5 - ILUSTRAÇÃO DO MÉTODO SWING . .82

TABELA 4.6 - VALORES DE CA EM FUNÇÃO DA ORDEM DA MATRIZ FONTE: PAMPLONA, 1999...... 86

TABELA 5.1 - EXEMPLO DE RESULTADO MOSTRADO PELO APLICATIVO. 103

TABELA 5.2 - RESUMO DA AVALIAÇ̃̃o DADA ÀS OITO ALTERNATIVAS DE GERAÇÃO QUANTO AOS CRITÉRIOS. 106

TABELA 5.4 - ClASSIFICAÇão DOS CRITÉRIOS UTILIZANDO O MÉTODO AHP.. 109

TABELA 5.5 - ClASSIFICAÇÃo FINAL UTILIZANDO o MÉTODO AHP 111

TABELA 5.6 - ClASSIFICAÇÃo FINAL UTILIZANDO o MÉTODO SWING 112

TABELA 5.8 - CLASSIFICAÇÃO FINAL APOS MODIFICADAS AS PRIORIDADES PARA OS CRITÉRIOS 113 


\section{INTRODUÇÃO}

\subsection{MOTIVAÇÃO DO TRABALHO}

$\mathrm{O}$ atendimento de energia elétrica às populações rurais brasileiras ainda não atendidas representa um enorme desafio para o país, pois se refere a um contingente de cerca de 10 milhões de pessoas, segundo Correia (2005). A ausência do fornecimento de eletricidade para estes brasileiros é sem dúvida uma séria exclusão social, tendo em vista as enormes oportunidades oferecidas pelo atendimento de energia elétrica nos dias de hoje, ou vista de outra forma, a falta deste atendimento constitui-se por si só uma supressão enorme de oportunidades para estas pessoas. Dentre os impactos ou custos sociais do nãofornecimento de energia elétrica a essa população pode-se citar: i) ao aumento das mazelas sociais provocadas pela migração de indivíduos aos centros urbanos em busca de melhores oportunidades; ii) as mortes causadas pelas deficiências na saúde pública local, como a inexistência de local adequado para armazenar vacinas; iii) o não-suprimento de educação adequada aos moradores; entre outros.

Diante dos crescentes negativos impactos ambientais e sociais causados pelo desenvolvimento econômico no planeta, nos moldes atuais, tem-se a geração de energia elétrica como uma das principais causas destes impactos. Mais recentemente o efeito estufa deixou de ser dúvida e passou a ser consenso pela comunidade científica internacional agravando a urgência de mudança de paradigma tecnológico, sob pena de duras, e até certo ponto imprevisíveis, conseqüências para humanidade.

A competição entre tecnologias não-renováveis e renováveis na produção de energia elétrica no mundo tende a ser muito desigual na maioria das vezes, exceto em locais com abundância de água onde hidrelétricas são muito viáveis. A menor viabilidade econômica das tecnologias mais limpas, em geral, tem diversos motivos como: o menor desenvolvimento tecnológico; a característica das fontes energéticas renováveis serem, em geral, pouco concentradas; e a existência de um grande lobby em torno do uso do petróleo. Dessa forma, o papel de se inserir os impactos ambientais e sociais na equação que decide a escolha da tecnologia pode ser fundamental para que alternativas menos danosas à sociedade e ao meio-ambiente possam competir com tecnologias convencionais e se estabelecerem no mercado. 
Tendo em vista a importância dos impactos ou custos sociais e ambientais provocados pela geração de energia elétrica, estes impactos não podem ser sistematicamente negligenciados frente ao aspecto econômico, especialmente no caso das comunidades isoladas. A análise e comparação de projetos de geração costumam se basear principalmente na avaliação econômico-financeira, entretanto, esta última não é capaz de levar em consideração os aspectos sociais, ambientais e técnicos inerentes aos projetos.

Em conseqüência do problema exposto acima, procura-se encontrar uma forma de avaliar os projetos de geração que envolva a questão econômica e os impactos ambientais e sociais provocados aplicados a comunidades isoladas. Dessa forma, quer-se quebrar o paradigma hegemônico do aspecto econômico frente aos aspectos sociais e ambientais referentes à geração de energia elétrica.

\subsection{OBJETIVO DO TRABALHO}

Este trabalho tem como objetivo construir uma metodologia de análise de projetos de geração de energia em comunidades isoladas, que envolva de forma mais ampla os aspectos relevantes na escolha de alternativas de geração, que devem incluir os aspectos sociais, ambientais e econômicos. Com o propósito de construir uma ferramenta capaz de promover e incentivar os tipos de geração mais ambientalmente e socialmente sustentáveis.

\subsection{ESTRUTURA DO TRABALHO}

Este trabalho é estruturado em seis capítulos com objetivos distintos entre si buscando desenvolver objetivos específicos, mas com complementaridade para construção do produto final deste trabalho.

O capítulo 2 tem o objetivo de apresentar os aspectos sociais relacionados ao atendimento energético das comunidades isoladas e informar sobre a problemática do fornecimento de energia elétrica nestas comunidades. Já o capítulo 3 tem por objetivo: fazer um apanhado geral das bases teóricas que envolvem os impactos provocados pela geração de energia elétrica; e apresentar as formas como que os impactos sociais e ambientais causados pela geração são abordados.

No capítulo 4, é explicada a metodologia proposta neste trabalho, que se propõe a inserir conjuntamente os diferentes aspectos da geração de eletricidade (aspectos sociais, ambientais, econômicos e técnicos) no processo de escolha e análise dos projetos ou alternativas de geração aplicadas a comunidades isoladas. 
O capítulo 5 apresenta o aplicativo desenvolvido para aplicação da metodologia do capítulo anterior, abordando os aspectos construtivos, a utilização do aplicativo, e o uso de exemplos para o teste do programa.

Por último, o capítulo 6, destina-se às conclusões do trabalho e sugestões para trabalhos futuros. 


\section{FORNECIMENTO DE ENERGIA ELÉTRICA A COMUNIDADES ISOLADAS E SEUS IMPACTOS SOCIAIS}

\subsection{A PROBLEMÁTICA DO FORNECIMENTO DE ENERGIA ELÉTRICA}

$\mathrm{O}$ atendimento de energia elétrica em comunidades isoladas no Brasil encontra uma série de dificuldades a serem enfrentadas. As estatísticas mostram que 10 milhões de pessoas que moram em regiões afastadas dos centros urbanos, principalmente na região amazônica, não possuem energia elétrica (Correia, 2005). Uma das grandes dificuldades para que estas comunidades sejam atendidas com eletricidade são as enormes distâncias entre estas comunidades e a geração centralizada, conforme apresentado na Figura 2.1. Isto, associado à pequena demanda local por este serviço, inviabiliza a construção de linhas de transmissão, exigindo que a geração seja do tipo Geração Distribuída e obriga a conversão energética no local. O custo estimado da instalação da rede convencional varia de R\$ $5.000,00$ a $\mathrm{R} \$ 10.000,00$ por $\mathrm{km} .^{1}$

\footnotetext{
${ }^{1}$ SIMPÓSIO BRASILEIRO DE MONITORAMENTO REMOTO. XIII, 2007, Florianópolis. Identificação de áreas potenciais para implantação de turbina hidrocinética através da utilização de técnicas de geoprocessamento. p. $2549-2556$.
} 


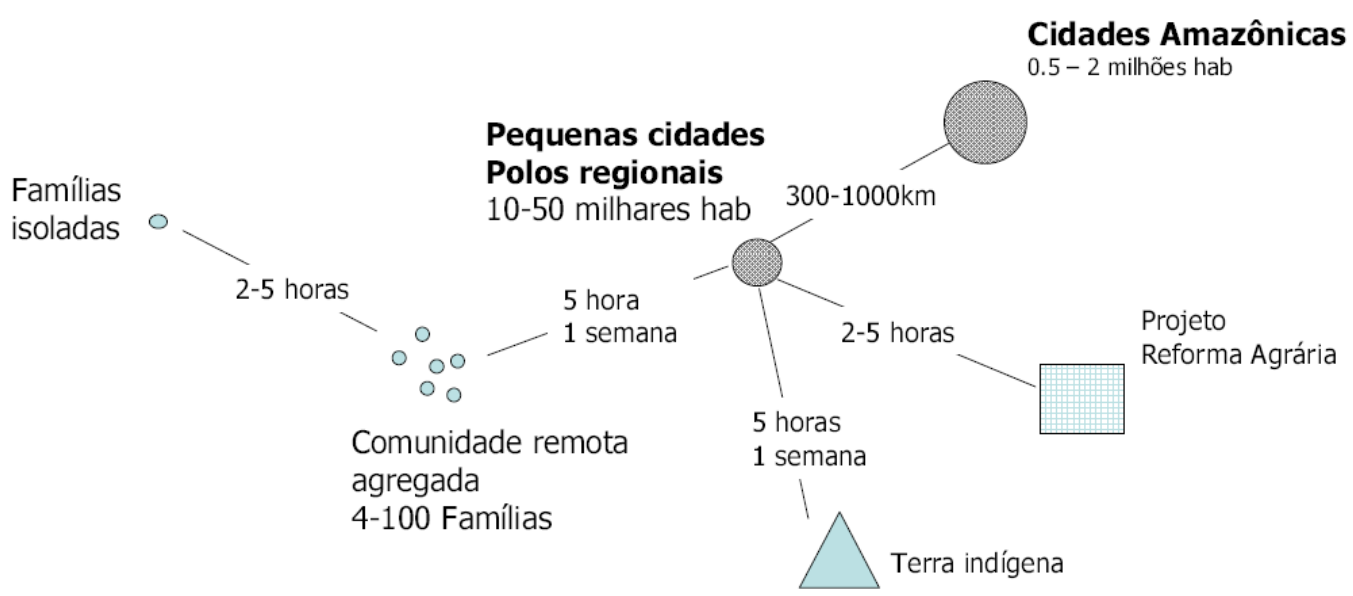

Figura 2.1 - Distâncias das comunidades isoladas

Fonte: BRASIL JUNIOR, Antônio C. P. Energia Renovável para reserva do Maracá. Disponível em: <www.mme.gov.br/download.do?attachmentId=10760\&download $>$. Acesso em: 02 de julho de 2008.

Nestas regiões, o gerador a dísel é a forma de geração distribuída predominante. No entanto, os altos custos deste tipo de geração vêm se elevando cada vez mais, motivados pelo aumento do combustível. Os altos custos associados à baixa renda dos moradores locais inviabilizam as comunidades isoladas como nichos de mercado para este tipo de geração. Como resultado, a grande maioria das comunidades isoladas na Amazônia não possui energia elétrica. No Estado do Amazonas, de um total de 4.600 comunidades, apenas 32 comunidades isoladas, cerca de 7\%, são supridas com energia elétrica (Correia, 2005).

Como reflexo deste precário abastecimento de energia elétrica, tem-se o degradante estado de miséria e pobreza nestas regiões, o que favorece a migração destas pessoas para as sedes de municípios mais próximos em busca de oportunidades aumentando das mazelas sociais nestas regiões.

É certo que o desenvolvimento econômico e social de uma sociedade guarda uma íntima relação com o consumo de energia, principalmente com energia elétrica. Portanto, a falta de disponibilidade de eletricidade prejudica ou inviabiliza o desenvolvimento destas comunidades.

Tendo em vista a baixa atividade econômica destas regiões e a falta de condições financeiras para bancar os custos da geração local, tem-se uma situação de insustentabilidade econômica (Correia, 2005) do fornecimento de energia elétrica às comunidades isoladas. 


\subsection{TIPOS DE COMUNIDADES ISOLADAS}

O mercado elétrico na região amazônica é dividido em três tipos (Souza, 2003): mercado elétrico das capitais, o mercado concentrado e o mercado disperso.

O mercado elétrico das capitais é atendido, em sua grande parte, por parques hidrotérmicos (hídricos e térmicos), que são de propriedade das concessionárias federais. Já o mercado concentrado corresponde às áreas urbanas dos municípios do interior dos Estados onde se localizam as termelétricas de médio porte de propriedade das concessionárias estaduais. Estas termelétricas utilizam, principalmente, os combustíveis derivados de petróleo, como o óleo dísel. Por último, o mercado disperso é composto de comunidades isoladas e se caracteriza como um mercado em desenvolvimento, sendo representado por grupos que não possuem o serviço de energia elétrica e que possuem pequenas unidades geradoras a dísel, normalmente cedidas por prefeituras municipais. O mercado disperso é ainda subdividido, segundo (Souza, 2003) em cinco grupos:

- Grupo I: populações tradicionais como seringueiros e pescadores, entre outros;

- Grupo II: populações tradicionais como extrativistas, seringueiros e ribeirinhos que habitam áreas de Reserva Extrativista;

- Grupo III: populações alocadas em áreas de reforma agrária;

- Grupo IV: populações de reservas indígenas;

- Grupo V: populações que não se enquadram nos grupos anteriores.

Estes cinco grupos representam bem o perfil das comunidades isoladas na Região Amazônica. Apesar das diferenças entres os grupos, eles têm em comum não apenas a carência de energia elétrica, mas também carência em outros setores, como educação, saúde, atividades geradoras de renda e outras infra-estruturas. Sendo assim, o atendimento do Estado a estas comunidades deve ser mais amplo que o simples atendimento da demanda energética, no sentido de propiciar o desenvolvimento social, cultural e econômico da Região. 
Existem basicamente dois modelos de fornecimento de energia elétrica às comunidades isolada ${ }^{2}$ : Energia como base apenas para o desenvolvimento local (modelo tecnicista) e Energia Integrada ao desenvolvimento local (modelo integrado). O modelo integrado, que combina parcerias locais, co-responsabilidade comunitária e desenvolvimento local, é o modelo preferível, mais adequado, por dar maior assistência a estas comunidades, aumentando as chances de haver um desenvolvimento sustentável. Já o modelo tecnicista, responsabiliza-se apenas por entregar a energia na comunidade, cobrando uma tarifa pelo serviço. A cobrança da tarifa, associada ao baixo rendimento da população, pode agravar a situação da população local se a disponibilidade da energia elétrica não resultar em aumento da renda dos moradores.

\subsection{BARREIRAS AO USO DE FONTES RENOVÁVEIS}

Há, na maioria das regiões do Brasil e em especial na Amazônia, abundância de fontes primárias renováveis de energia. As principais fontes renováveis presentes na Região Amazônica são: a fotovoltaica, hidrocinética, biomassa (lenha, resíduos florestais, óleos vegetais) e eólica (presente em algumas regiões). No entanto, a utilização destas fontes renováveis para produção de energia elétrica ainda encontra muitas barreiras. Estas barreiras, segundo Correia (2005), são as seguintes:

- O alto investimento inicial necessário em tecnologias de transformação;

- Tecnologias não consolidadas (exemplo: biomassa);

- A inexistência de tecnologia de transformação em pequena escala;

- O desconhecimento do consumidor/investidor da existência de facilitadores disponibilidade de crédito, matéria-prima, regulação do setor, entre outros destinados a incentivar a inserção dessas fontes na matriz energética nacional.

\footnotetext{
${ }^{2}$ BRASIL JUNIOR, Antônio C. P. Energia Renovável para reserva do Maracá. Disponivel em: < www.mme.gov.br/download.do?attachmentId=10760\&download $>$. Acesso em: 02 de julho de 2008.
} 
Como reflexo desse quadro, o mercado de sistemas de geração por fontes renováveis de pequeno porte se encontra num ciclo vicioso, em que a demanda retraída a estes produtos não favorece a diminuição dos custos de produção, e a demanda não aumenta devido aos altos custos de produção.

Entretanto, a utilização de fontes renováveis de energia locais em substituição aos combustíveis fósseis, em especial àqueles não disponíveis na região, possibilita uma série de impactos positivos tanto sociais como ambientais: dinamização da economia local; redução da dependência externa aos combustíveis (fósseis); geração de empregos; diminuição de emissões atmosféricas; e, ainda incentiva alternativas mais sustentáveis ambientalmente.

A solução para que sejam ultrapassadas as barreiras à geração de energia por fontes renováveis deve envolver políticas de longo prazo que incentivem a produção de sistemas de geração em menor escala para se tornarem competitivos e a melhoria socioeconômica das regiões isoladas. Dessa forma, cumpre ao Estado o papel fundamental de subsidiar as alternativas energéticas em comunidades isoladas para quebrar o ciclo vicioso em que este mercado se encontra.

\subsection{A IMPORTÂNCIA DO ATENDIMENTO ENERGÉTICO DAS COMUNIDADES ISOLADAS}

$\mathrm{O}$ atendimento energético às comunidades isoladas, sob o ponto de vista econômico, é desinteressante, porém as externalidades positivas do suprimento de energia elétrica nestas localidades são muitas e corroboram para que este atendimento energético deva ser visto como um investimento social. O fornecimento de energia elétrica a estas comunidades tem um enorme potencial na melhoria das condições de vida dos moradores. Estima-se que cerca de 15 milhões de brasileiros não tenham acesso à energia elétrica, destes, 10 milhões estão situados em regiões rurais (Correia, 2005).

Deve-se atentar para o fato de que o não fornecimento deste serviço básico para as pessoas pode representar um custo muito maior que o custo de subsidiar a geração local. A falta de energia elétrica está associada ao não-atendimento de uma série de direitos sociais, como direito à educação e à saúde, garantidos pela Constituição Federal (artigo $6^{\circ}$ ), como dever do Estado. 
A quantificação dos prejuízos ou custos causados pela falta energia elétrica é complexa e cheia de incertezas, na medida em que envolve os seguintes aspectos relacionados: i) ao aumento das mazelas sociais provocadas pela migração de indivíduos aos centros urbanos em busca de melhores oportunidades; ii) as mortes causadas pelas deficiências na saúde pública local, como a inexistência de local adequado para armazenar vacinas; iii) o nãosuprimento de educação adequada aos moradores; entre outros.

Apesar de não haver uma valoração confiável do custo social associado à falta de acesso à energia elétrica por parcela considerável da população, é muito provável que este valor seja superior ao custo de subsídio da energia elétrica devido à enorme gama de limitações econômicas e sociais impostas aos moradores destas regiões.

Os esforços em se responder se é ou não vantajoso custear a geração de eletricidade em comunidades rurais isoladas, devem estar voltados para responder a seguinte pergunta: qual é a melhor forma de levar eletricidade a estas comunidades?

\subsection{INCENTIVOS DO ESTADO À GERAÇÃO EM COMUNIDADES ISOLADAS}

Os incentivos à geração e o atendimento básico das comunidades isoladas podem ser considerados incipientes, fato comprovado pelo descaso em que se encontram estas comunidades. Os investimentos sociais nestas áreas, que englobam o acompanhamento e auxílio a estas comunidades, têm acontecido de forma desencontrada, mal estruturada e ocorrido de maneira centralizada, com pouca participação da população local. Por essa razão, faz-se necessária a criação de mecanismos eficientes de relação com estas comunidades, no sentido de descentralizar e de viabilizar a articulação com instituições locais; princípios básicos, segundo Ferreira e Andrade (2002) para o sucesso de qualquer projeto social.

Segundo Ferreira e Andrade (2002), existem, no Brasil, poucas estruturas regionais e setoriais detentoras de tecnologias renováveis passíveis de serem utilizadas como suporte para a implantação de geração de energia elétrica nas comunidades isoladas. Das poucas estruturas existentes que atuam em fontes renováveis, muitas foram criadas há pouco mais de cinco anos, num esforço do Ministério da Ciência e Tecnologia para a implantação de Centros de Referência Nacionais como CENBIO, CBEE, CERPCH, que se referem respectivamente, à biomassa, energia solar e Pequena Central Hidrelétrica (PCH). 
Alguns incentivos públicos podem ser destacados quanto a sua relação com o atendimento às comunidades isoladas. Entre eles podem-se destacar: a Conta de Consumo de Combustíveis Fósseis dos Sistemas Isolados - CCC-ISOL, o PROINFA e o LUZ PARA TODOS.

A CCC foi criada com a intenção de subsidiar as despesas com combustíveis fósseis na geração de energia elétrica ${ }^{3}$, a fim de impulsionar o crescimento em regiões isoladas do Sistema Interligado Nacional (SIN). O subsídio à geração com combustíveis fósseis se dá pelo reembolso dos custos obtidos na geração das regiões ditas isoladas. Esta verba é obtida pelo rateio dos custos em nível nacional, bancado em grande parte pelos consumidores do SIN. Mais recentemente, com o aumento do preço do petróleo e a insustentabilidade do modelo de geração por combustíveis fósseis, a Conta de Consumo de Combustíveis (CCC) passou a beneficiar também as alternativas renováveis de geração de energia e a diminuir os subsídios à geração a base de petróleo. Para ter direito ao reembolso dos custos da geração devem ser seguidos procedimentos definidos pela ANEEL $^{4}$. Apesar de beneficiar as regiões isoladas do sistema interligado, a CCC-ISOL acaba por beneficiar diretamente apenas os 'mercados das capitais' e o 'mercado concentrado', definidos anteriormente. Já o 'mercado disperso', composto por pequenas comunidades e com pequena capacidade de geração de energia, não é comumente atendido, dado que para se sub-rogar os benefícios da CCC são necessários procedimentos dificultosos quando se considera pequena geração, como aquela gerada por grupo de motor-gerador numa pequena comunidade. Desta forma, a CCC falha em não beneficiar as pequenas comunidades isoladas, apesar de beneficiar as capitais dos estados e municípios.

3 A geração a partir do petróleo é o tipo predominante nas regiões isoladas do SIN, principalmente na região Norte. Este modelo de geração foi por muito tempo considerado o mais viável para fornecer eletricidade em locais eletricamente isolados.

\footnotetext{
${ }^{4}$ Para maiores informações buscar na internet o 'Guia para utilização de recurso da CCC', ANEEL.
} 
Já o Programa de Incentivo as Fontes Alternativas de Energia Elétrica - PROINFA criado pela Lei $\mathrm{n}^{\mathrm{o}} 10.438$, de 26 de abril de 2002, e revisado pela Lei $\mathrm{n}^{\mathrm{o}} 10.762$, de 11 de novembro de 2003, caracteriza-se como um importante instrumento para a diversificação da matriz energética nacional uma vez que garante maior confiabilidade e segurança ao abastecimento. No entanto, infelizmente, não atende especificamente o problema das Comunidades Isoladas, fato esse corroborado pelo objetivo do PROINFA expresso na Lei 10.438/2002: “aumentar a participação da energia elétrica produzida por empreendimentos de Produtores Independentes Autônomos, concebidos com base em fontes eólica, pequenas centrais hidrelétricas e biomassa, no Sistema Elétrico Interligado Nacional”. O fato de citar apenas o Sistema Elétrico Interligado Nacional descredencia o PROINFA como programa de incentivo às comunidades isoladas.

Em 2004, o Governo Federal iniciou o "Programa Nacional de Universalização do Acesso e Uso da Energia Elétrica - Luz para Todos" com o objetivo de levar energia elétrica para a população do meio rural. Esse Programa é coordenado pelo Ministério de Minas e Energia com a participação da Eletrobrás e de suas empresas controladas, e conta com recursos somados superiores a 7 bilhões de reais. Apesar de ambicioso, o programa LUZ PARA TODOS não é, ou pelo menos não foi, efetivo em disponibilizar energia elétrica em comunidades isoladas, já que se concentrou na eletrificação rural de comunidades próximas às redes convencionais. Com relação ao atendimento às comunidades isoladas, o programa encontra-se em estágio inicial, conforme comprovam os seguintes fatos: o programa está mapeando vilas isoladas ${ }^{5}$ e apresentou, recentemente, projetos-pilotos para o atendimento de comunidades isoladas em parceria com o $\mathrm{MCT}$ e o $\mathrm{CNPq}^{6}$. Desta forma, o

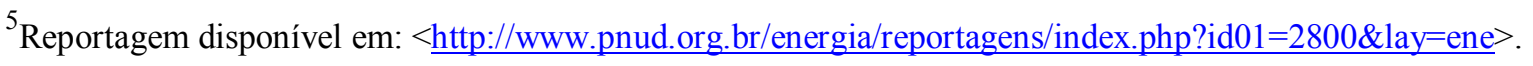
Acesso em 27 de junho de 2007.

${ }^{6}$ Reportagem disponível em:

$<\underline{\text { http://www.mme.gov.br/site/news/detail.do;jsessionid=5E9FD24FE96CE529B910B7BC87C54860?newsId }}$ $=12702 \&$ currentArea $>$. Acesso em 27 de junho de 2007.
} 
programa é, talvez, a política pública mais direcionada para as comunidades isoladas. Essa análise, no entanto, carece de resultados mais concretos.

Além dos incentivos públicos ao atendimento às comunidades, existem investimentos sociais privados nesta área, liderados por Organizações Não-Governamentais - ONGs e empresas. Não é raro encontrar maior eficácia nos investimentos sociais privados quando comparados com os programas governamentais. Talvez a melhor solução para as políticas públicas nesta área, passe por parcerias com prefeituras, organizações populares e ONGs, como salientam Ferreira e Andrade (2002) em seu trabalho.

\subsection{CONSIDERAÇÕES FINAIS}

De acordo com que foi visto nesse capítulo, o fornecimento de energia elétrica para comunidades isoladas é considerado um projeto social por abranger mais do que somente a geração de eletricidade local. O perfil das comunidades isoladas é, em geral, de baixo rendimento o que inviabiliza, na maioria dos casos, o financiamento da alternativa de geração local com recursos próprios.

Foi visto que os mercados de energia nas regiões isoladas do Sistema Integrado na Região Amazônica, podem ser divididos em três tipos: das capitais, concentrado e disperso, onde o mercado disperso representa as comunidades isoladas que podem ser segregadas em grupos distintos, de acordo com suas atividades.

Apesar de serem abundantes na Região Amazônica, as fontes renováveis encontram barreiras para se consolidarem como principais fontes energéticas na geração de energia. Entre as principais barreiras, destacam-se a falta de sistemas de geração comercial em pequena escala e a falta de sistemas consolidados de transformação energética. Isto contribui para um ciclo vicioso, onde a demanda por tais sistemas não cresce por causa dos altos preços, e os preços não abaixam pela pequena demanda existente.

$\mathrm{O}$ atendimento energético às comunidades isoladas faz parte das atribuições do Estado para com seus cidadãos como parte dos direitos sociais, segundo a Constituição Federal. Este atendimento está associado a uma gama enorme de necessidades que não podem ser atendidas, ou ficam seriamente comprometidas, na ausência de energia elétrica. Apesar das despesas para o fornecimento de energia elétrica não poderem ser pagos pelos usuários, tais despesas são provavelmente menores que os custos dos prejuízos sociais causados às 
comunidades e poderiam ser, por essa razão, custeados pelo Estado na forma de investimento social.

Apesar disto, os incentivos do Estado ou as políticas públicas voltadas ao fornecimento de energia elétrica para comunidades isoladas podem ser consideradas incipientes e ineficazes, haja vista a precariedade da situação nestas comunidades. Recentemente, têm ocorrido investimentos mais vultosos nesta área social por parte do governo, com destaque para o programa LUZ PARA TODOS, embora os resultados estejam aquém do desejado. 


\section{IMPACTOS DA GERAÇÃO DE ENERGIA ELÉTRICA E AS SUAS ABORDAGENS: QUANTITATIVA E MULTICRITÉRIO}

\subsection{CONSIDERAÇÕES INICIAIS}

Como visto no capítulo anterior, os impactos ambientais e sociais, principalmente estes últimos, são de grande importância para os moradores de comunidades isoladas. No entanto, resta a seguinte questão: como e qual a melhor forma de levar em conta estes aspectos (social e ambiental) frente ao aspecto econômico? Este capítulo propõe-se a levantar bases teóricas para responder esta questão.

É sabido que a geração de energia elétrica produz impactos diretos e indiretos à sociedade. Eles são divididos neste trabalho em duas categorias: ambiental e social. A definição proposta neste trabalho para estes dois tipos de impactos são:

- Ambientais: se caracterizam como impactos onde ocorre uma mudança das condições ambientais com efeitos para os indivíduos e para o meio ambiente. Como exemplo tem-se: a poluição atmosférica, da água e do solo; aquecimento global; danos ao ecossistema.

- Sociais: ocorrem em decorrência direta ou indireta do uso de energia elétrica, como a melhoria da qualidade de vida e a geração de empregos e renda como conseqüência da disponibilidade de eletricidade.

Embora estes dois tipos de impactos não tenham fronteiras claras entre si, eles servem para distinguir algumas classes de impactos considerados sociais (como geração de empregos, diminuição do êxodo rural e desenvolvimento de atividades produtivas correlatas devido ao uso de eletricidade) dos impactos ambientais. Quanto aos considerados impactos ambientais, que tratam de danos à saúde e danos econômicos provocados por poluição, apesar de estes últimos constituírem danos à sociedade, em tese, eles serão considerados impactos ambientais para manter a coerência com o sentido usual desses termos.

Na ultimas décadas, significativos progressos têm sido alcançados no desenvolvimento de técnicas para análise dos impactos sociais e ambientais causados pela produção e consumo de eletricidade (ExternE-Pol, 2004). Pode-se identificar duas principais correntes que analisam estes impactos: a Neoclássica, externalidades, e a Institucional, multicritério, (Sang-Hoon King, 2007). A corrente Neoclássica enxerga os impactos sociais e ambientais como externalidades ou custos externos. O conceito de externalidades tem um sentido mais 
restrito, e refere-se aos impactos externos causados pela atividade humana, excluindo os impactos de quem oferta e consome os serviços ou produtos, que são considerados internos. Nesta abordagem, as externalidades são consideradas falhas de mercado e são analisadas de acordo com a economia do bem-estar social. Já a corrente Institucional, com a abordagem multicritério, rejeita a visão Neoclássica ao encarar os impactos negativos não apenas como falhas de mercado, mas também como falhas Institucionais. Considera os impactos de maneira mais ampla, incluindo os impactos internos acima referidos. Como alternativa aos custos externos, a análise Institucional lança mão da quantificação de custos sociais e do uso de métodos multicritérios de análise qualitativa, que incluem métodos quantitativos.

Estas duas diferentes abordagens dos impactos da geração de energia elétrica são apresentadas neste capítulo buscando compreendê-las para se chegar a uma estrutura ou modelo mais adequado, capaz de inserir os impactos sociais e ambientais no processo de escolha dos tipos de geração aplicados a comunidades isoladas. Portanto, procura-se fazer valer os aspectos sociais, ambientais e econômicos na escolha da geração de energia elétrica em comunidades isoladas, que são particularmente muito sensíveis aos aspectos sociais. Deseja-se quebrar o paradigma de que o aspecto econômico é hegemônico e, às vezes, o único considerado na decisão da alternativa de geração de energia.

\section{ESTRUTURA DO CAPÍTULO}

Este capítulo 3 é bem amplo e aborda desde aspectos conceituais dos impactos e das externalidades, as formas de análise e de apropriação destes impactos no processo decisório, até as políticas que devem ser adotadas para solucionar as chamadas falhas de mercado. Na seção 3.2 é apresentada uma contextualização da relação das atividades energéticas com outras áreas e suas influências mútuas. Já a seção 3.3 discorre sobre o tema Externalidade. Iniciando-se pela explicação do aspecto conceitual das Externalidades, justificando as razões que levam a teoria econômica a considerar as externalidades como falhas de mercado que conduzem à ineficiência alocativa na sociedade. Mais adiante são explicadas as diferenças entre as externalidades na produção e no consumo. Propostas de soluções para chamada falha de mercado causada pelas externalidades são enunciadas, podendo demandar intervenções privadas ou públicas. As soluções privadas são apresentadas, assim como a sua principal base teórica, Teorema de Coase (Prado, 2007). Já as soluções públicas são divididas em dois tipos: soluções de regulação e controle e 
soluções baseadas no mercado. Por fim, são analisadas as diferentes soluções e os aspectos pertinentes a cada tipo.

Na seção 3.4 são introduzidos os dois tipos básicos de abordagens dos impactos da geração de energia, a abordagem quantitativa e a multicritério.

Já a seção 3.5 trata da abordagem quantitativa que se empenha em calcular os custos externos da geração. Os objetivos e a finalidade da quantificação dos custos externos são apresentados na seção 3.5.2. Na seção seguinte, são vistos as principais metodologias, topdown e bottom-up, assim como um resumo da evolução histórica científica desta abordagem. A seção 3.5.4 apresenta a metodologia causal Impact Pathway Approach (IPA), classificada como bottom-up, utilizada para atribuir os custos externos das atividades humanas, baseada nos trabalho do grupo ExternE. E por fim, são apresentadas as contribuições da quantificação dos custos externos como estratégia para orientar políticas públicas que visam a reduzir os impactos externos causados pela geração de energia.

A abordagem e os métodos multicritérios são apresentados na seção 3.6. Os elementos estruturais e os procedimentos que envolvem a análise multicritério são introduzidos nesta seção, assim como os principais métodos múlticritérios e a comparação entre eles.

\subsection{INTER-RELAÇÕES DAS ATIVIDADES ENERGÉTICAS}

Atividades humanas como conversão de energia, indústria, transporte ou agricultura causam significativos danos ao meio ambiente e à saúde humana que variam conforme a atividade e o local, causando impactos sociais e ambientais, que, em sua grande maioria, não estão embutidos no sistema de preço ou não são levados em conta no processo decisório sobre investimentos e desenvolvimento de tecnologias [6]. A inter-relação entre as atividades produtivas vem sendo cada vez mais estudada e evidenciadas com o auxílio tecnológico e o avanço organizacional da sociedade, possibilitando a obtenção de dados e o seu processamento [6].

Ao se falar no tema energia, deve-se levar em consideração o seu caráter multidisciplinar, na medida em que envolve diversas áreas do conhecimento, e exige uma abordagem sistêmica, que englobe outros aspectos que não só o econômico e o tecnológico, tendo em vista o papel imprescindível da energia para o desenvolvimento da sociedade. 
A sociedade atual sem o uso da energia não existiria. Falar em produção de energia sem considerar seus impactos positivos e negativos na sociedade não faz muito sentido. Portanto, pode-se associar o tema energia com as seguintes esferas: social, ambiental, econômica, tecnológica, de materiais e política.

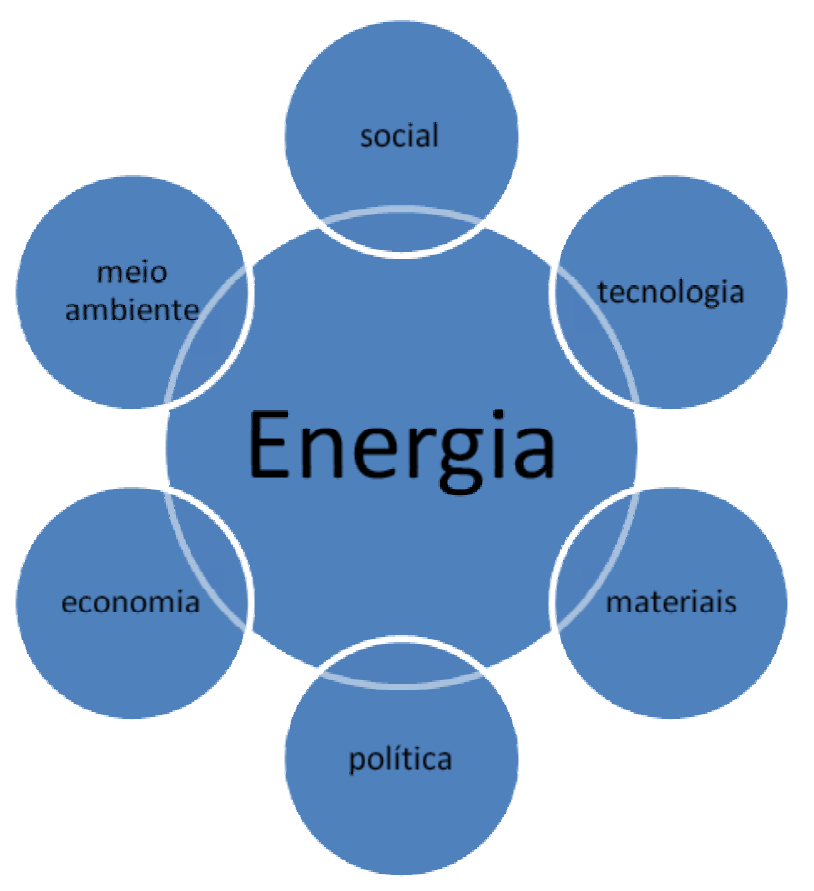

Figura 3.1 - Diagrama com questões inter-relacionadas a energia.

É interessante notar que qualquer atividade, principalmente atividades energéticas, causa certo dano ao meio ambiente, por menor que seja. As formas de interferência da produção de energia para o meio ambiente, hoje em dia, são mais difundidas e claras, entre as quais podemos citar: o alagamento ocasionado por hidrelétricas, ameaçando de extinção determinadas espécies da fauna e flora; o dano radioativo do lixo nuclear para o meio onde for despejado; o enxofre emitido pela queima do carvão causando chuvas ácidas, etc. Já as relações entre a quantidade de energia consumida e o grau de desenvolvimento econômico de uma sociedade andam muito próximas, particularmente no perfil de desenvolvimento da chamada Era Industrial (Tessmer). As duas revoluções industriais fizeram surgir uma necessidade imensa de energia para viabilizar os processos industriais.

As tecnologias, os materiais e os combustíveis empregados na geração de energia determinam o tipo e o grau do impacto ambiental. Podemos inserir, também, os impactos 
sociais causados por este tipo de geração, como a quantidade de empregos gerada por este tipo de produção ou, ainda, as facilidades e as dificuldades geradas pelo uso de determinado tipo de geração de energia em relação a outro. Por fim, ao se encarar as decisões políticas relacionadas no setor de energia em resposta às demandas da sociedade aos impactos sociais causadas pela produção e uso da própria energia, fica clara a interrelação: o papel da política em muitos momentos da história foi o de dar direção e rumo aos processos e às atividades humanas, sendo, portanto, algo que deva ser considerado. No entanto, existe uma tendência de se achar que a economia controla e dita todos os rumos seguidos pela humanidade.

\subsection{EXTERNALIDADES}

\subsubsection{ASPECTOS CONCEITUAIS}

O termo Externalidade tem origem nas ciências econômicas e refere-se aos impactos externos provocados por determinada atividade, econômica ou não. Uma externalidade existe quando uma ação individual afeta o bem-estar de outro indivíduo - tanto para o bem quanto para o mal - de forma que não precisa ser pago de acordo com a existente definição de direito de propriedade na sociedade. ${ }^{7}$

No processo de produção e consumo de eletricidade, diversos impactos a terceiros que são causados por esta atividade não estão incluídos no sistema de preço de compra e venda. As externalidades - ou custos externos - da geração de eletricidade podem ser definidas como todos os impactos negativos ou positivos causados pelo uso de determinada tecnologia que modifica a utilidade de outros sem permissão ou compensação adequada. Os custos externos surgem quando uma atividade social ou econômica de um grupo de pessoas tem impacto em outro grupo e quando este impacto não é totalmente levado em conta pelo primeiro grupo [6].

As externalidades podem ser classificadas, conforme Prado (2007) em:

\footnotetext{
About.com Economics. Dicionário de economia. Disponível em:

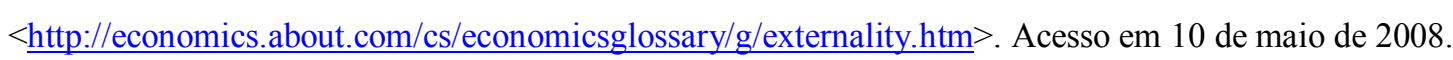


Externalidades positivas, onde o efeito de determinada atividade tem efeito indireto ou externo positivo, que tende a beneficiar outros grupos ou pessoas.

Externalidades negativas - produzem efeito prejudicial a outras atividades ou outras pessoas, que não diretamente ligadas à atividade em questão.

\subsubsection{EXTERNALIDADES E INEFICIÊNCIA DO MERCADO}

$\mathrm{Na}$ hipótese de inexistência de externalidades num mercado em perfeita concorrência, o interesse da sociedade no mercado, ou o bem-estar social, ocorre em consonância com a maximização do bem-estar dos compradores e vendedores (figura 3.2). Ou seja, o equilíbrio de preço e quantidade do mercado é encontrado pelas curvas de oferta e demanda individuais, e corresponde ao equilíbrio ótimo, segundo a economia do bem-estar social, onde há a maximização do bem-estar da sociedade (Prado, 2007).

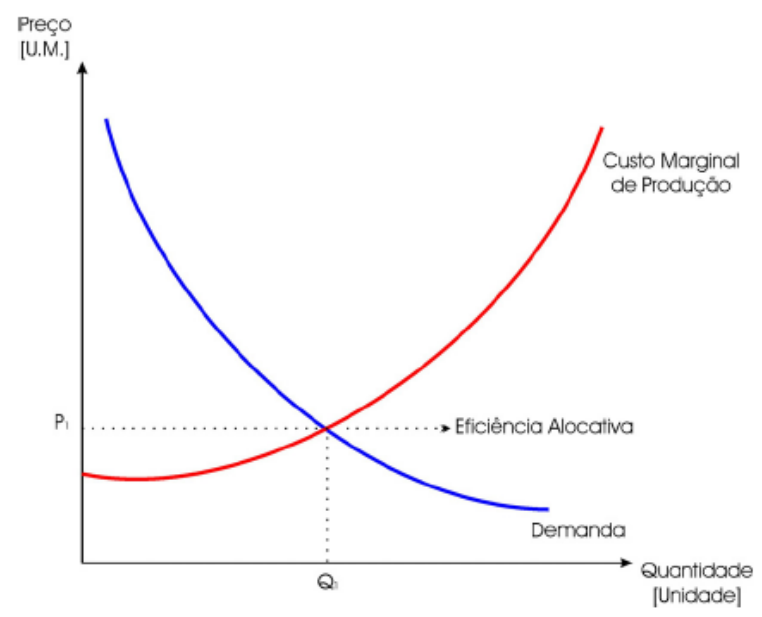

Figura 3.3- Exemplo de equilíbrio de mercado

Fonte: PRADO, Thiago G. Ferreira. Externalidades do ciclo produtivo de cana de açúcar com ênfase na produção de energia elétrica. 2007. 236 f. Dissertação (Mestrado em Engenharia) - Universidade de São Paulo, São Paulo, 2007.

A economia do bem-estar referida preocupa-se com o bem-estar dos indivíduos, em vez de grupos, comunidades ou sociedades. O bem-estar social refere-se ao estado utilitário total da sociedade. Freqüentemente, ele é definido como a soma do bem-estar de todos os indivíduos da sociedade [21]. Entretanto, a existência de externalidades positivas e negativas cria um problema para a efetiva maximização utilitária total da sociedade pelo mercado. As ofertas e demandas de produtos, de acordo com a teoria econômica clássica, não levam em conta os custos e os benefícios que não são diretamente sentidos por ela. Uma maneira mais intuitiva de compreender a ineficiência econômica provocada pela existência de externalidades é entender que esta ineficiência decorre de um dano ou 
benefício gerado a outros que não são pagos. É bastante natural o entendimento de que se um causa algum dano a outro, este "um" deve ressarcir o "outro".

As externalidades podem surgir na produção e (ou) no consumo (Prado, 2007). Para tanto, podemos separar didaticamente as externalidades na produção das no consumo. No entanto elas podem ocorrer simultaneamente, isto é, a co-ocorrência das externalidades tanto na produção quanto no consumo.

\subsubsection{EXTERNALIDADES NA PRODUÇÃO}

As externalidades na produção podem ser classificadas como positivas ou negativas. Quando as externalidades ocorrem durante o processo de produção de determinado produto ou bem e decorrem exclusivamente do processo produtivo, podem ser chamadas de externalidades na produção. Quando há externalidades na produção, o custo da sociedade para a produção deste bem ou produto é diferente do custo do produtor. E, isto se reflete em diferentes curvas de oferta (equivalente ao custo marginal de produção) deste produto, distinguindo a curva Oferta Social da Curva de Oferta do Produtor. O custo marginal social é composto pelo custo do produtor adicionado ao custo marginal externo, que pode ser negativo ou positivo (figura abaixo).
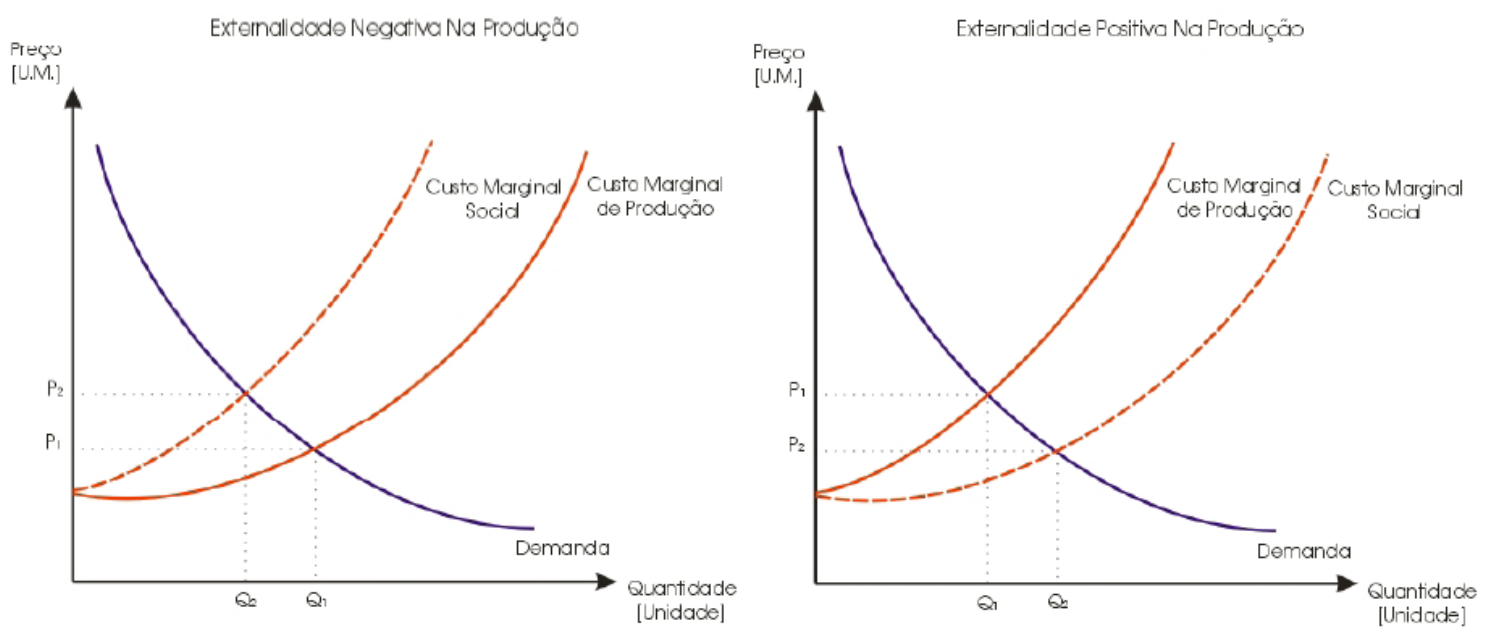

Figura 3.5 - Ilustração da externalidade negativa e positiva na produção, respectivamente. Fonte: PRADO, Thiago G. Ferreira. Externalidades do ciclo produtivo de cana de açúcar com ênfase na produção de energia elétrica. 2007. 236 f. Dissertação (Mestrado em Engenharia) - Universidade de São Paulo, São Paulo, 2007.

Neste novo cenário, surge outro ponto de equilíbrio que é o ponto $\left(\mathrm{Q}_{2}, \mathrm{P}_{2}\right)$, onde as Curvas de Custo Marginal Social e a Demanda se encontram. Este novo ponto corresponde ao equilíbrio ótimo, do ponto de vista da sociedade. No entanto, num mercado sem qualquer 
regulação o equilíbrio ótimo não é atingido, pois o custo marginal sentido pelo produtor está alheio às externalidades. $\mathrm{O}$ ponto de equilíbrio encontrado pelo mercado, que neste caso é o $\left(\mathrm{Q}_{1}, \mathrm{P}_{1}\right)$, é um ponto sub-ótimo e não maximiza o bem-estar da sociedade. Maneiras para solucionar este tipo problema, que correspondem a formas de internalizar as externalidades, são apresentadas mais adiante.

O exemplo mais conhecido de externalidade é a poluição atmosférica causada em determinadas indústrias ou até mesmo em plantas geradoras de energia. A poluição neste caso causa impactos negativos para sociedade em geral (doenças respiratórias, aquecimento global, chuvas ácidas, etc.), sendo um exemplo de externalidade negativa na produção.

Já um exemplo possível, elaborado neste trabalho, de atividade com externalidade positiva na produção são empresas de reciclagem de produtos. Neste caso os rejeitos, como latas de alumínio, que possuem impacto ambiental negativo passam a ser insumos na indústria de reciclagem. Além disto, o fato de reutilizar os rejeitos evita a extração na natureza de minerais, processo com impactos ambientais também negativos.

\subsubsection{EXTERNALIDADES NO CONSUMO}

As externalidades no consumo, assim como na produção, também podem ser negativas ou positivas, e correspondem aos efeitos indiretos gerados pelo consumo de produtos ou bens que venham a influenciar outras atividades, grupos ou indivíduos, positivamente ou negativamente. Há, portanto, uma diferença entre a demanda social (ou benefício marginal social) e a demanda individual (benefício marginal individual) (Prado, 2007). 

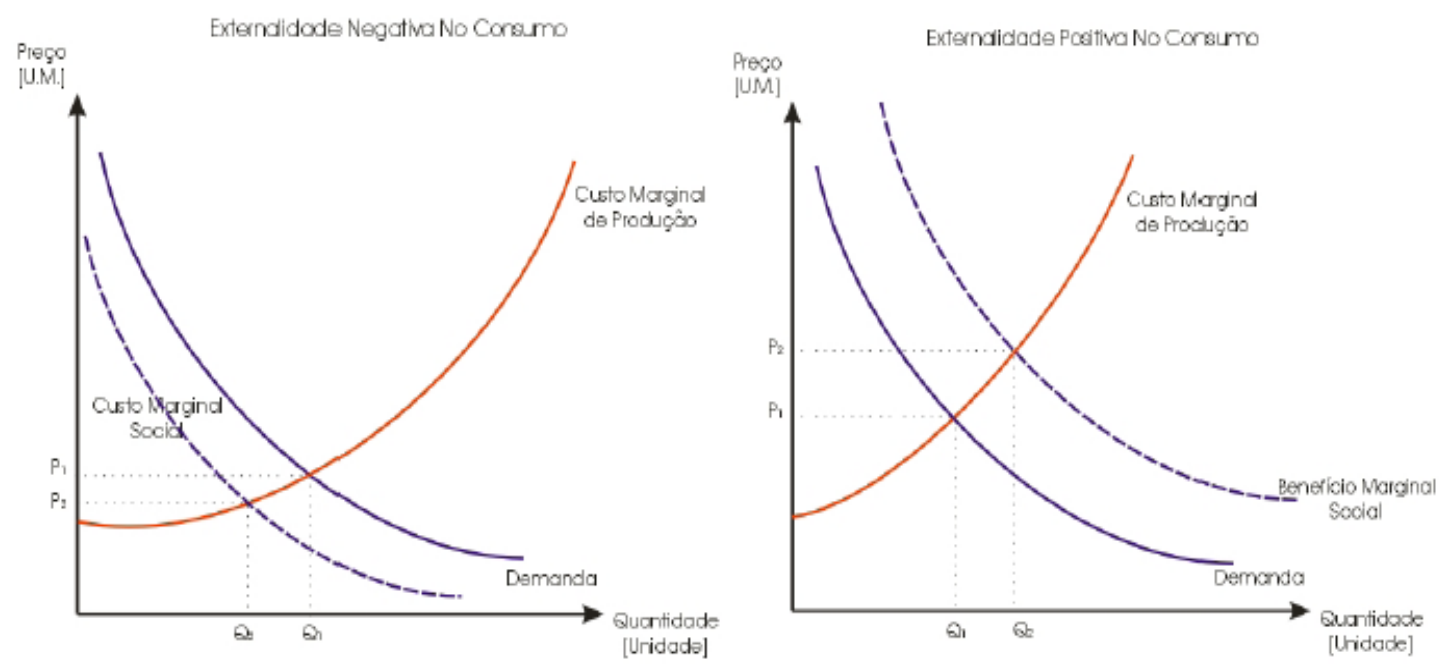

Figura 3.7 - Exemplo de externalidade negativa e positiva no consumo, respectivamente. Fonte: PRADO, Thiago G. Ferreira. Externalidades do ciclo produtivo de cana de açúcar com ênfase na produção de energia elétrica. 2007. 236 f. Dissertação (Mestrado em Engenharia) - Universidade de São Paulo, São Paulo, 2007.

Desta forma, surge outro ponto de equilíbrio ilustrado pela figura acima, que ocorre quando a demanda social é igual à oferta, que representa a quantidade e o preço ótimos, que maximizam o bem-estar social. E assim como na externalidade na produção, o ponto de equilíbrio encontrado pelo mercado possui quantidade produzida superior à ótima quando a externalidade é negativa, e possui quantidade produzida inferior à ótima quando a externalidade é positiva.

Como exemplo, proposto neste trabalho, de externalidade negativa no consumo, tem-se a emissão de poluentes por automóveis e os congestionamentos nas grandes cidades, que causam efeitos negativos, estão indiretamente ligados ao consumo de automóveis. Neste caso pode-se dizer que, dependendo do local, do combustível usado e de seus tipos de poluentes, a compra e a venda de automóveis possuem externalidades negativas no consumo. Este exemplo pode gerar polêmica e a crítica de que a externalidade da poluição é uma externalidade do consumo de combustíveis e não do automóvel. Isto de fato é verdade, mas na medida em que tais questões estão inter-relacionadas e é impossível separá-las: sem o carro não haveria o consumo de combustível.

Já a externalidade positiva no consumo pode ser exemplificada com o uso de produtos químicos 'ecologicamente corretos' na agricultura, que não degradam o meio ambiente. Ao deixar de usar produtos químicos mais nocivos ao ecossistema e utilizar produtos menos nocivos, o efeito de consumir tais produtos pode ser considerado positivo para a sociedade 
e o meio ambiente. Entretanto, esta questão pode ser vista de outro ângulo: ao caracterizar o consumo de produtos químicos muito nocivos com grande externalidade negativa no consumo e caracterizar o produto pouco nocivo ao meio ambiente com pequena (menor) externalidade negativa. Apesar disto, é certo que a diferença entre estas duas externalidades deve corresponder à externalidade positiva citada anteriormente.

É difícil e aparentemente inócuo atribuir à origem exata às externalidades, ou seja, não parece ser relevante se a origem se dá no consumo ou na produção. Para fins de políticas públicas para internalizar as externalidades ou a corrigir esta falha de mercado, as externalidades no consumo ou na produção se equivalem. No entanto, o que parece mais importante é a distinção entre externalidade positiva e negativa. E, de fato, em muitas situações reais as externalidades que surgem são de origem múltipla, tanto da produção quanto do consumo.

Da discussão entre externalidades na produção e no consumo alguns itens podem ser ressalvados:

- Externalidades positivas induzem ao mercado produzir quantidades inferiores as socialmente desejáveis. Um dos possíveis remédios seria a aplicação de subsídios; e

- Externalidades negativas induzem ao mercado à produção em quantidades superiores as socialmente desejáveis. Um remédio possível seria a aplicação de taxas.

\subsubsection{SOLUÇÕES PARA AS EXTERNALIDADES}

A existência de externalidades no mercado cria a chamada falha de mercado que torna ineficiente a alocação de recursos pelo mercado com vistas a atender apenas os interesses dos compradores e dos vendedores. Umas das formas mais clássicas de internalização das externalidades positivas e negativas é a criação de subsídios e taxas respectivamente. Entretanto, estas formas não são as únicas soluções (Prado, 2007).

Podem-se dividir as soluções para externalidades em dois tipos: soluções privadas e soluções públicas. Apesar de atuarem de formas distintas no mercado, ambas compartilham um objetivo comum, que é o de mover a alocação de recursos para o ótimo social. 


\subsubsection{SOLUÇÕES PRIVADAS PARA AS EXTERNALIDADES}

Embora possa parecer que o único tipo de solução para as falhas de mercado provocadas pelas externalidades sejam soluções de Estado, em algumas circunstâncias as soluções privadas podem corrigir falhas existentes. As soluções privadas partem normalmente de interesses mútuos entre os agentes seguidos de um acordo. A solução pode ter o formato de integração entre diferentes tipos de negócio. Outra maneira com que o mercado lida com efeitos externos é através de contratos entre as partes interessadas com a possibilidade de transferência de capital procurando encontrar um ótimo alocativo (Prado, 2007).

A Comissão Interna de Prevenção de Acidentes (CIPA) é um exemplo possível proposto neste trabalho, como um tipo de solução privada as externalidades que envolvem principalmente os acidentes de trabalho, que podem ser vistos como externalidades na construção civil. Nela os interesses dos trabalhadores e empregadores são discutidos e soluções em forma de acordos são encontradas no sentido de melhorar as condições de trabalho. ${ }^{8}$

\section{O TEOREMA DE COASE}

O teorema de Coase é um ponto de sustentação teórica para as soluções privadas das externalidades. O teorema diz que se os agentes envolvidos com as externalidades puderem negociar ou barganhar, sem custos de transação, e a partir de direitos de propriedade bem definidos pelo Estado, eles poderão negociar e chegar a um acordo em que as externalidades serão internalizadas [20]. No entanto, o teorema de Coase não se mostra muito prático, principalmente quando é grande o número de envolvidos pela externalidade. São muitos os exemplos em que o teorema de Coase falha, tem-se como o exemplo desta falha o encerramento do Festival Internacional de Sidmouth no Reino Unido. Neste exemplo, a soma dos benefícios diretos e externos do festival era bem superior aos custos

${ }^{8}$ A CIPA é uma comissão composta por representantes do empregador e dos empregados, e tem como missão a preservação da saúde e da integridade física dos trabalhadores e de todos aqueles que interagem com a empresa. Ela é regida pela lei ${ }^{\circ} 6.514$ de 22/12/77 e regulamentada pela NR-5 do Ministério do Trabalho. 
totais, porém os agentes envolvidos não conseguiram um acordo para que o festival continuasse existindo. ${ }^{9}$

O pressuposto de que os custos de transação sejam nulos é irreal, o que pode ser apontado como um dos principais motivos para a falha do teorema. Outro fator que pesa negativamente ao teorema, é a falta de aplicação concreta dos direitos individuais e de propriedade na sociedade, bem como, a incerteza de aplicação de sanções negativas caso eles sejam caso violados. Isto dificulta o processo de negociação e de barganha por parte dos afetados pela externalidade.

Em especial, acordos são de difícil aplicação, principalmente quando o número de partes interessadas é grande face aos custos de coordenar cada um deles. O fato de nem todos os envolvidos conhecerem as necessidades uns dos outros dificulta a escolha do agente adequado para um processo de acordo (Prado, 2007).

\subsubsection{SOLUÇÕES PÚBLICAS PARA AS EXTERNALIDADES}

As respostas do Estado para ajustar as falhas de mercado provocadas pela existência de externalidades são divididas em duas formas de políticas, por (Prado, 2007):

- de comando e controle, onde a atuação é feita de forma direta visando regular a atividade; ou,

- baseadas no mercado, onde se aplica um sinal econômico que o mercado resolva o problema por sua conta, sendo visto como uma forma menos intrusiva.

É muito importante que o Estado, antes de fazer uso de qualquer tipo de intervenção, conheça os detalhes do mercado em questão, tanto para a escolha da intervenção mais adequada para o caso, como para evitar erros com conseqüências sérias para o mercado. As respostas de políticas públicas a fim de ajustar as falhas de mercado provocadas pela existência de externalidades são divididas em dois tipos por (Prado, 2007): políticas de comando e controle; e políticas baseadas no mercado.

\footnotetext{
${ }^{9} \mathrm{O}$ caso detalhado está disponível em: $<\underline{\text { http://www.seered.co.uk/folk89.htm }>}$.
} 


\subsection{POLÍTICAS DE COMANDO E CONTROLE}

\section{REGULAÇÃO}

O Estado pode tentar controlar o nível das externalidades ocorridas com a fixação de patamares mínimos, médios ou máximos que devem ser controlados e supervisionados pelo estado. Isso visa, portanto, o controle do comportamento dos agentes econômicos por decretos ou leis contendo critérios a serem obedecidos, sendo passível de multas caso haja discordância. ${ }^{10}$

\section{TAXAS PIGOUVIANAS E SUBSÍDIOS}

Para alinhar os incentivos privados com a eficiência social, o governo pode lançar mão de taxas ou subsídios à determinada atividade. Dessa forma, na presença de externalidades positivas o governo fornece subsídios incentivando a atividade, e na presença de externalidades negativas o governo cria taxas para desincentivar a atividade.

As taxas pigouvianas são taxas que visam corrigir efeitos das externalidades. Ao contrário da taxação comum sobre produtos que constituem entraves para o equilíbrio ótimo social, as taxas pigouvianas tem a função de ajuste para que o ótimo social seja atingido, em ambas taxas o Estado arrecada do contribuinte. Em tese esta arrecadação deveria ser transferida para os que sofrem os efeitos da externalidade.

As taxas pigouvianas frente à regulação possuem algumas vantagens. Uma delas é que as taxas favorecem uma distribuição das reduções das externalidades de forma mais eficiente e com menores custos, isto é, a aplicação de taxa sobre a externalidade em diferentes setores causadores da externalidade favorece que os setores com menor custo de diminuição do impacto reduzam mais que os outros. Já a regulação, obriga uma redução igual das externalidades causadas, independente do setor e seus custos para a diminuição. O uso da taxa pigouviana também pode ser vantajoso sob o ponto de vista da melhoria das tecnologias para reduzir os impactos. Outro aspecto da regulação é que não há nenhum

\footnotetext{
${ }^{10}$ A Resolução do CONAMA no $382 / 2006$, que estabelece limites máximos de emissão de poluentes para fontes fixas, ela é um exemplo de regulação do Estado.
} 
incentivo à empresa cujos impactos externos estão dentro do limites legais, como fazer uso de tecnologias menos impactantes; já a aplicação de taxas acaba por incentivar todas as empresas no desenvolvimento de tecnologias menos impactantes.

A grande dificuldade das taxas pigouvianas é determinar uma taxa ótima tendo em vista ausência e assimetria das informações para seu estabelecimento tal taxa, visando otimizar o bem-estar social. As taxas pigouvianas aplicadas em um caso concreto podem ser baixas demais ou excessivamente altas, não é fácil encontrar o equilíbrio.

\subsection{POLÍTICAS BASEADAS NO MERCADO COMERCIALIZAÇÃO DE PERMISSÕES}

A política de comercialização de permissões pode ser considerada uma forma de regulação flexível, que estabelece quantidades-limite, mas flexibiliza permitindo que se comercializem permissões, como as permissões de poluição.

Este instrumento de política pública pode ser exemplificado da seguinte forma. O governo fixa um padrão de total de toneladas de dióxido de enxofre por ano. Este total é dividido entre as empresas. Cada poluidor passa a dispor de uma cota de $\mathrm{SO}_{2}$ (dióxido de enxofre) a ser emitida. Se forem incorporadas novas tecnologias mais "limpas" por determinadas indústrias, a ponto de suas emissões ficarem abaixo da cota, estas mesmas empresas podem vender seus créditos remanescentes para outros poluidores, que estão dispostos a pagar a mais por poluir além de suas cotas. Os poluidores podem escolher qual caminho é mais vantajoso em termos de custo: despoluir e vender (as licenças) ou continuar a poluir e comprar. Observe que a quantidade de poluição emitida é a mesma e, do ponto de vista do bem-estar econômico; a alocação é feita de maneira mais eficiente.

O comércio de créditos de carbono no mundo é um bom exemplo da política de concessão de permissões. Neste mercado atuam empresas interessadas em comprar créditos de carbono (permissão para emissão de $\mathrm{CO}_{2 \mathrm{eq}}$ ) e outras em vender.

Apesar da comercialização de permissões parecerem diferentes das taxas pigouvianas, as duas políticas têm muito em comum. Ambas as empresas poluidoras são obrigadas a pagar por poluir, sendo que uma paga para outras empresas e a outra paga para o Estado. No caso da comercialização de permissões as empresas que ofertam suas permissões no mercado estão recebendo o valor referente ao custo de oportunidade de poluir. 

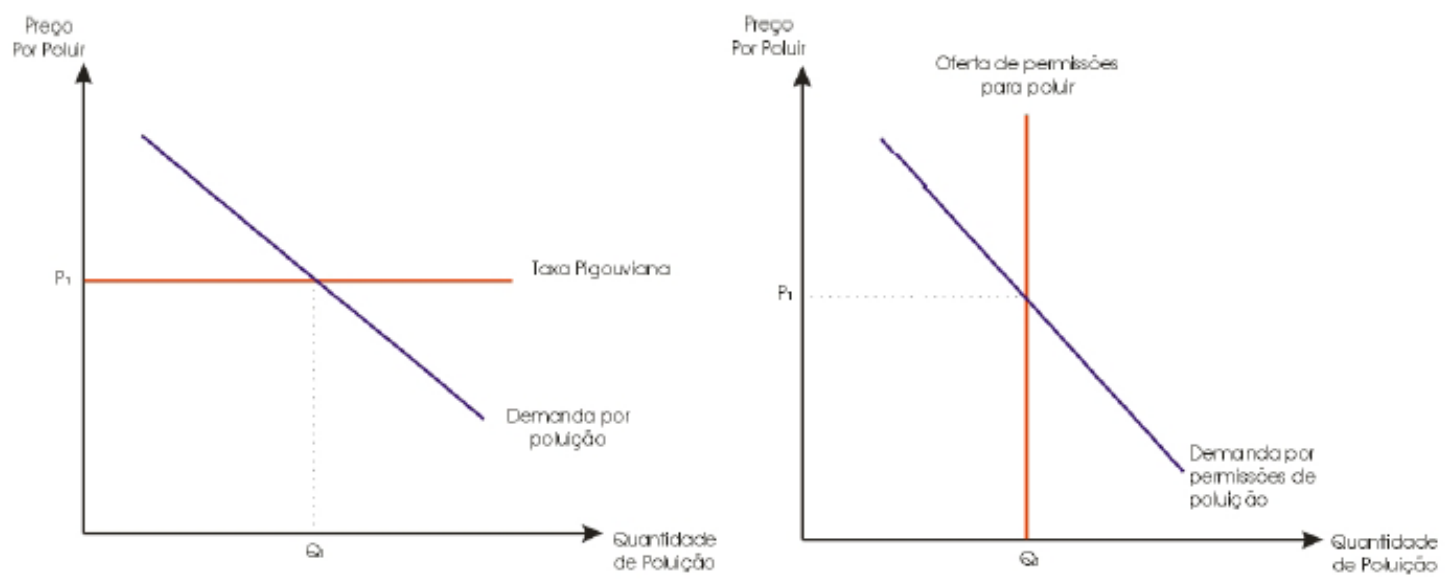

Figura 3.9- Exemplo de taxa pigouviana e comercialização de permissões.

Fonte: PRADO, Thiago G. Ferreira. Externalidades do ciclo produtivo de cana de açúcar com ênfase na produção de energia elétrica. 2007. 236 f. Dissertação (Mestrado em Engenharia) - Universidade de São Paulo, São Paulo, 2007.

As similaridades entre as taxas pigouvianas podem ser vistas na Figura 3.9- Exemplo de taxa pigouviana e comercialização de permissões.. Observe no gráfico da taxa pigouviana que o preço fixado da poluição é representado pela curva perfeitamente elástica. $\mathrm{Na}$ comercialização de permissões o que é fixado é a quantidade de poluição, representada pela curva perfeitamente inelástica. Em tese, ambas as soluções conduzem a uma eficiência alocativa dos recursos.

A comercialização de permissões pode ser a melhor opção nos casos onde não se conhece a demanda da externalidade do mercado e onde há um interesse em limitar a quantidade da externalidade. Pois, para se conseguir limitar as externalidades com o uso da taxa pigouviana seria necessário o levantamento da curva da demanda para se determinar o valor da taxa.

\subsubsection{CONSIDERAÇÕES FINAIS SOBRE AS EXTERNALIDADES}

As externalidades podem ser negativas ou positivas. $\mathrm{O}$ fato da origem das externalidades estarem na produção ou no consumo do produto ou serviço talvez não seja tão relevante, ainda mais quando se está fazendo uma idealização de um mercado, segundo a teoria neoclássica econômica.

O ponto mais importante, na análise da externalidades, é identificá-las como falhas de mercado que conduzem a sociedade a um estado de ineficiência. Portanto, as externalidades devem ser consideradas nas atividades humanas, sobretudo pelo Estado deve estar atento a elas para prover instrumentos para corrigir esta ineficiência. 
Alguns aspectos relevantes em relação às vantagens e às desvantagens dos diferentes tipos de soluções para as externalidades podem ser levantados:

- Soluções exclusivamente privadas dificilmente ocorrem principalmente devido aos altos custos de transação para se obterem acordos com todos os agentes envolvidos, com o agravante de quanto maior for o número de partes envolvidas, mais difícil é o acordo;

- Políticas de comando e controle tendem, pelo aparato institucional envolvido, a ser um processo mais lento e oneroso, além das dificuldades frente à diversidade de processo, atividades, etc.(Prado, 2007). Tais alterações devem ser acompanhadas de informações confiáveis para a justa medida da remediação;

- O uso da regulação permite que níveis de externalidades sejam adotados com maior confiabilidade, porém deixa incertos os custos para abatimento.

- A taxa pigouviana é um instrumento que permite o mercado alocar eficientemente os recursos e incentiva o desenvolvimento de tecnologias menos impactantes. No entanto, este instrumento requer grandes quantidades de informações dos impactos e do mercado para serem corretamente elaborados.

- A comercialização de permissões possui a mesma vantagem da regulação, que é a adoção de níveis confiáveis de externalidades, associada à minimização dos custos de abatimento possibilitada pelo comercio de permissões. No entanto, demanda que os agentes conheçam as preferências entre si, o que não é usual.

Quanto às soluções para as externalidades, conclui-se que não existe solução adequada a todos os casos. A determinação da melhor política depende, conseqüentemente, da natureza da incerteza, do comportamento das curvas de custo para o setor em questão e da disponibilidade e qualidade das informações para caracterizar o custo externo (Prado, 2007).

\subsection{TIPOS DE ABORDAGENS DOS IMPACTOS SOCIAIS E AMBIENTAIS}

Significativos progressos têm sido alcançados no desenvolvimento de técnicas para análise dos impactos sociais e ambientais causados pela produção e consumo de eletricidade [6]. Podemos identificar duas principais correntes que analisam estes impactos: Neoclássica, quantitativa, e a Institucional, multicritério (Sang-Hoon King, 2007).

A abordagem quantitativa ou corrente Neoclássica (custos externos) enxerga os impactos sociais e ambientais como falhas de mercado e analisa as externalidades baseadas no principio da economia do bem-estar social. Os métodos de quantificação baseados na 
corrente Neoclássica se desenvolveram bastante ultimamente, tem-se como exemplo o trabalho desenvolvido pelo grupo ExternE. Já a abordagem multicritério, ou corrente Institucional, rejeita a visão Neoclássica ao encarar os impactos negativos não apenas como falhas de mercado, mas também como falhas Institucionais. Como alternativas aos custos externos, a análise Institucional lança mão da quantificação de custos sociais, considerados internos ao comércio de energia elétrica, e do uso de métodos multicritérios de análise qualitativa, que incluem também métodos quantitativos.

Estas duas abordagens serão apresentadas nas próximas seções deste capítulo.

\subsection{ABORDAGEM QUANTITATIVA DOS IMPACTOS EXTERNOS DA GERAÇÃO - CUSTOS EXTERNOS}

\subsubsection{INTRODUÇÃO}

Com base no conceito econômico de externalidade, desenvolveram-se diversos estudos sobre os custos externos da geração de energia elétrica, que envolvem principalmente os danos à saúde e os danos ao meio ambiente causados na produção de energia elétrica.

Os esforços dos estudos sobre os custos externos visam, principalmente, quantificar o dano ou benefício externo gerado pela atividade de geração. A partir destes dados podem ser formuladas políticas para corrigir as chamadas falhas de mercado.

\subsubsection{PROPÓSITOS DE QUANTIFICAR OS CUSTOS EXTERNOS}

As atividades humanas, econômicas ou não, podem causar danos aos próprios seres humanos, ao ecossistema e aos materiais. Em especial, o setor de eletricidade é responsável por boa parte da emissão de poluentes são prejudiciais à saúde humana e ao ecossistema. Os danos externos gerados dependem, fundamentalmente, da tecnologia empregada e da fonte de energia utilizada.

Nos sistemas de comércio sem qualquer tipo de regulação o único elemento de incentivo ou desincentivo ao uso de diferentes tipos de geração é o custo econômico direto da geração, representado pelo índice $\$ / \mathrm{kWh}$. Neste caso as tecnologias mais baratas, independentemente dos seus impactos externos, tendem a ser incentivadas.

Já nos mercados atuais de forma geral, com algum tipo de regulação, os produtores de energia não têm incentivos para contabilizar os danos externos na geração. O dever do produtor de energia é apenas o de respeitar os limites de emissão impostos pela legislação 
ambiental (ExternE, 2005). Os danos ou benefícios do uso de determinadas tecnologias para sociedade como um todo não são levados em consideração. Os impactos externos causados são muitos e distintos (ex: emissão de $\mathrm{CO}_{2}$, diminuição da expectativa de vida por problemas de saúde causados, eutrofização, chuvas ácidas): o desafio é compará-los. Para isto, deve-se usar uma unidade em comum. A unidade mais adequada parece ser a unidade monetária devido a uma série de vantagens: maior liquidez, ordem de grandeza mais familiar (devido ao contato diário que se tem) e por se inserir os impactos externos diretamente no mundo econômico ou dos negócios (ExternE, 2005).

A quantificação dos custos externos tem papel essencial numa análise geral e mais completa das atividades, em particular a geração de eletricidade. Entre as aplicações da quantificação dos custos externos pode-se citar: a avaliação das alternativas tecnológicas de maneira mais completa (incluindo os custos externos) influenciando o processo decisório para investimentos futuros nos tipos de geração. Nisto está incluída a comparação entre alternativas de geração que pode fomentar o uso da tecnologia com melhores impactos externos, além de servir como incentivo para melhoria das outras tecnologias.

Outra funcionalidade da quantificação dos impactos externos é a possível influência que esta informação pode exercer no consumo de produtos (ExternE, 2005), como a busca de produtos de menor impacto pelos consumidores, já que o comércio de produtos também é fonte de impactos externos. Um exemplo de produto que possui impactos externos elevados são os automóveis, cujos impactos externos explicitados em forma de custos gerados podem servir de desincentivo ao consumo deste bem.

Os custos externos quantificados podem servir também como ferramenta para o uso da análise custo-benefício das atividades econômicas, a fim de orientar políticas públicas para reduzir os impactos ambientais e à saúde humana (ExternE, 2005).

\subsubsection{BREVE HISTÓRICO DO ESTUDO DOS CUSTOS EXTERNOS}

Os estudos sobre os custos externos ou custos sociais da geração de eletricidade começaram no final dos anos 1970, mas somente no final dos anos 1980 se desenvolveu uma estrutura mais compreensiva e científica para quantificação dos custos externos a geração de eletricidade. Podem-se identificar duas principais metodologias para quantificar os custos externos: a top-down e bottom-up. (Sang-Hoon King) 
Na metodologia top-down são feitas estimativas dos danos genéricos causados em nível nacional ou regional, divididos em categorias de impactos, e então atribuídos às emissões para se determinar o custo por unidade de emissão. Esta metodologia necessita de um conjunto de dados confiáveis sobre os danos e as emissões. Por exemplo, os custos externos totais causados pela emissão de $\mathrm{SO}_{2}$ numa região (como danos ao ecossistema, corrosão de paredes, problemas respiratórios e outros) são estimados e divididos pelo total de emissões $\mathrm{SO}_{2}$ da região, obtendo-se o custo externo total por unidade emitida de enxofre.

Já a metodologia bottom-up percorre o caminho oposto, que se inicia na emissão local de um poluente e estimam-se os danos marginais causados, fazendo uso de modelos de dispersão, funções de resposta à exposição ao poluente e a multiplicação dos impactos por seu valor monetário. É conhecida também como Impact Pathway Approach (IPA) e possui um caminho mais lógico de quantificação das externalidades (ExternE, 2005). As análises dos custos externos são de natureza local e são, em princípio, intransferíveis, isto é, não aplicáveis a outros locais.

A análise bottom-up com base no método do custo de dano, passou a ser a técnica dominante enquanto o metodo top-down foi utilizado predominantemente nos anos 80 e 90 (Prado, 2007).

\subsubsection{IMPACT PATHWAY APPROACH}

A metodologia bottom-up é considerada uma forma mais coerente de quantificar as externalidades causadas da geração de energia. Neste caso, cada localidade de geração de energia elétrica possui um impacto particular, o que é bem razoável intuitivamente.

Dentro desta classe de metodologia bottom-up em destaca-se a metodologia Impact Pathway Approach. O IPA é dividido em quatro etapas mostradas abaixo e ilustrada pela Figura 3.11 - Etapas do IPA.

1) Emissão - Coleta dos dados de emissão da geração em questão expressa em kg de partículas emitidas por GWh, por exemplo.

2) Dispersão - Cálculo do aumento da concentração do poluente nas regiões afetadas utilizando modelos computacionais de dispersão.

3) Impacto - Cálculo da exposição cumulativa ao poluente, e em seguida calcula-se o impacto desta exposição usando funções dose-resposta. 
4) Valoração monetária - É a multiplicação dos impactos pelos valores monetários estimados.

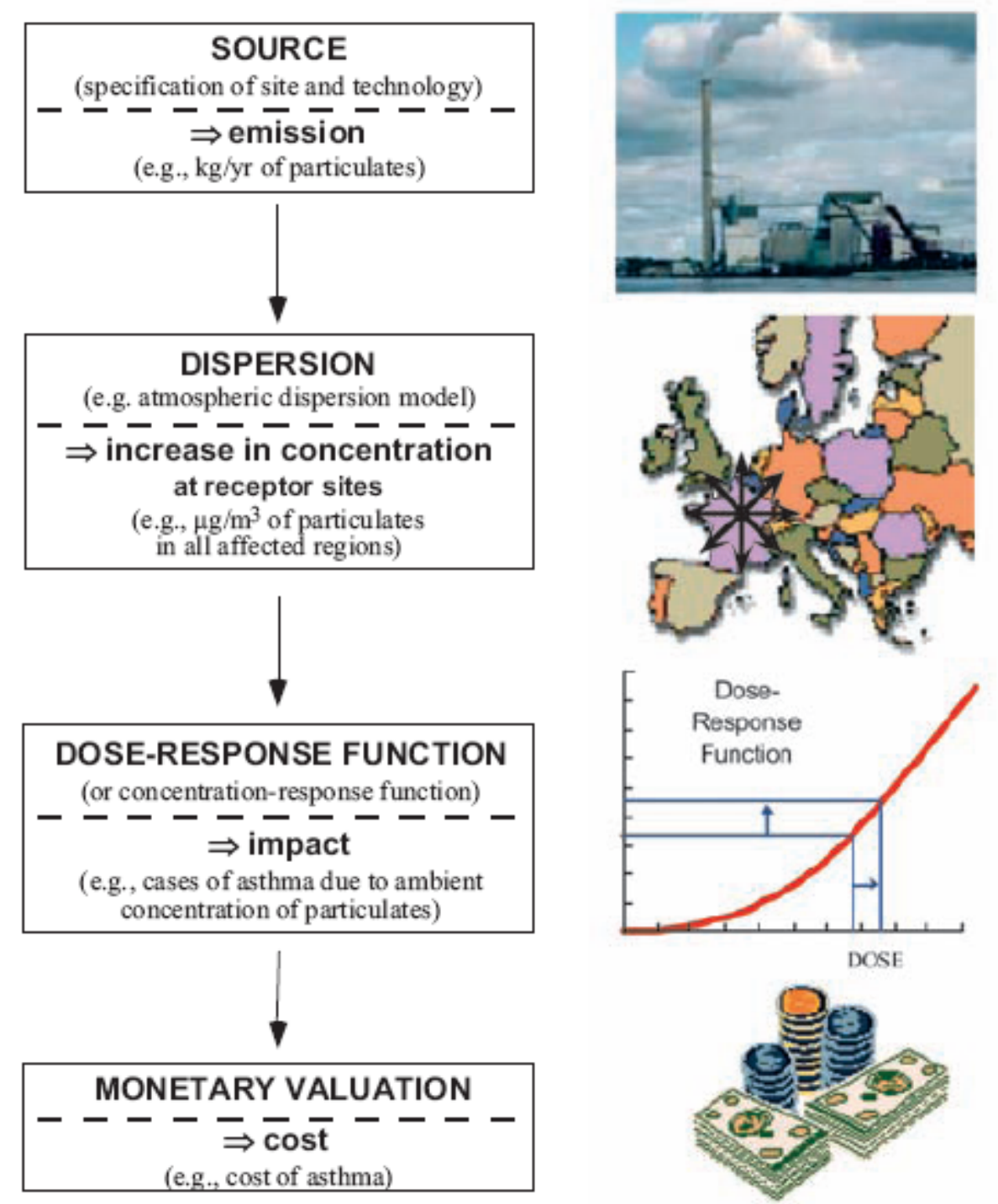

Fonte: EXTERNE. Externalities of Energy. Metodology 2005 Update. Stuttgard, 2005. Metodology Update 2005.

Figura 3.11 - Etapas do IPA

Para se calcular os danos causados pela poluição provocada por atividades como a geração de eletricidade, é necessário traçar um caminho lógico a ser percorrido por este poluente, como mostra a Figura 3.11.

Os impactos contabilizados nesta análise são os considerados relevantes. Estes são modelados por receptores que apresentam respostas às concentrações de poluentes, como o aumento da freqüência de entradas em hospitais devido ao aumento da emissão de gases 
prejudiciais à saúde. Faz-se uso, então, das chamadas das funções Dose-Resposta ou Concentração-Resposta.

Observe que a metodologia IPA requer uma análise multidisciplinar que envolve engenheiros, ecologistas, economistas, 'modeladores de dispersão', epidemiologistas.

\subsubsection{TIPOS IMPACTOS DA GERAÇÃO DE ENERGIA}

Os impactos da geração de eletricidade são diversos, como já mencionados. No entanto pode-se dividi-los em categorias. A metodologia ExternE apresenta a seguinte divisão dos impactos em categorias:

1) Impactos Ambientais: São impactos causados por lançamento de partículas ou energia (ruído, calor, radiação) no nos ambientes: água, solo e ar. Onde é utilizado o Impact Pathway Approach.

2) Aquecimento Global: Os danos dos impactos do aquecimento global são estimados, mas devido a grandes incertezas existentes utiliza-se o método dos custos evitados (avoidance costs).

3) Acidentes: Acidentes que não são esperados em situação normal de operação podem ser divididos em impactos que são o publico em geral, e riscos ocupacionais ou acidentes de trabalho.

Os impactos da geração podem ser bem sintetizados conforme a tabela a seguir, que relaciona os principais poluentes ou substâncias emitidas com seus impactos causados. 
Tabela 3.2 - Lista de poluentes e seus impactos à saúde.

EXTERNAL COSTS OF ENERGY AND TRANSPORT:

IMPACT PATHWAYS OF HEALTH AND ENVIRONMENTAL EFFECTS INCLUDED IN THE ANALYSIS

\begin{tabular}{|c|c|c|}
\hline Impact Category & Pollutant / Burden & Effects \\
\hline \multirow[t]{3}{*}{$\begin{array}{l}\text { Human Health } \\
\text { - mortality }\end{array}$} & $\begin{array}{l}\mathrm{PM}_{20}^{2}, \mathrm{SO}_{2} \\
\mathrm{NOx}_{3} \mathrm{O}_{3}\end{array}$ & Reduction in life expectancy \\
\hline & $\begin{array}{l}\text { Benzene, } \\
\text { Benzo-[a]-pyrene } \\
\text { 1,3-butadiene } \\
\text { Diesel particles }\end{array}$ & Cancers \\
\hline & $\begin{array}{l}\text { Noise } \\
\text { Accident risk }\end{array}$ & $\begin{array}{l}\text { Loss of amenity, impact on health } \\
\text { Fatality risk from traffic and workplace accidents }\end{array}$ \\
\hline \multirow{8}{*}{$\begin{array}{l}\text { Human Health } \\
\text { - morbidity }\end{array}$} & $\mathrm{PM}_{30}, \mathrm{O}_{3}, \mathrm{SO}_{2}$ & Respiratory hospital admissions \\
\hline & $\mathrm{PM}_{50}, \mathrm{O}_{3}$ & Restricted activity days \\
\hline & $\mathrm{PM}_{30}, \mathrm{CO}$ & Congestive heart failure \\
\hline & $\begin{array}{l}\text { Benzene, } \\
\text { Benzo-[a]-pyrene } \\
\text { 1,3-butadiene } \\
\text { Diesel particles }\end{array}$ & Cancer risk (non-fatal) \\
\hline & $\mathrm{PM}_{\mathbf{1 0}}$ & $\begin{array}{l}\text { Cere bro-vascular hospital admissions } \\
\text { Cases of chronic bronchitis } \\
\text { Cases of chronic cough in children } \\
\text { Cough in asthmatics } \\
\text { Lower respiratory symptoms }\end{array}$ \\
\hline & $\mathrm{O}_{3}$ & $\begin{array}{l}\text { Asthma attacks } \\
\text { Symptom days }\end{array}$ \\
\hline & Noise & $\begin{array}{l}\text { Myocardial infarction } \\
\text { Angina pectoris } \\
\text { Hyperten sion } \\
\text { Sleep disturbance }\end{array}$ \\
\hline & Accident risk & Risk of injuries from traffic and workplace accidents \\
\hline \multirow[t]{2}{*}{ Building Material } & $\begin{array}{l}\mathrm{SO}_{2} \\
\text { Acid deposition }\end{array}$ & $\begin{array}{l}\text { Ageing of galvanised steel, limestone, mortar, sand-stone, paint, rendering, } \\
\text { and zinc for utilitarian buildings }\end{array}$ \\
\hline & Combustion particles & Soiling of buildings \\
\hline Crops & $\begin{array}{l}\mathrm{NO}_{x}, \mathrm{SO}_{2} \\
\mathrm{O}_{3} \\
\text { Acid deposition }\end{array}$ & $\begin{array}{l}\text { Yield change for wheat, barley, rye, oats, potato, su gar beet } \\
\text { Yield change for wheat, barley, rye, oats, potato, rice, tobacco, sunflower seed } \\
\text { Increased need for liming }\end{array}$ \\
\hline GlobalWarming & $\begin{array}{l}\mathrm{CO}_{2}, \mathrm{CH}_{4}, \mathrm{~N}_{2} \mathrm{O} \\
\mathrm{N}, \mathrm{S}\end{array}$ & $\begin{array}{l}\text { World-wide effects on mortality, morbidity, coastal impacts, a griculture, energy } \\
\text { demand, and economic impacts due to temperature change and sea level rise }\end{array}$ \\
\hline Amenity losses & Noise & Amenity losses due to noise exposure \\
\hline Ecosystems & $\begin{array}{l}\text { Acid deposition, } \\
\text { nitrogen deposition }\end{array}$ & $\begin{array}{l}\text { Acidity and eutrophication (avoidance costs for reducing areas where critical } \\
\text { loads are exceeded) }\end{array}$ \\
\hline
\end{tabular}

Fonte: EXTERNE. Externalities of Energy. Metodology 2005 Update. Stuttgard, 2005. Metodology Update 2005.

Como pode ser observado na tabela acima os impactos à saúde se destacam e são responsáveis pela maior parte das estimativas dos custos externos, com destaque para as taxas de mortalidade que compõem maior peso no custo total dos impactos à saúde.

\subsubsection{CONTRIBUIÇÃO DOS ESTUDOS DOS CUSTOS EXTERNOS}

A quantificação dos custos externos tem como principal objetivo estimar os custos externos gerados por determinadas atividades, como a geração de eletricidade. $\mathrm{O}$ uso desta informação (custo externo) tem diversas aplicações no sentido de balizar as atividades humanas em questão, para um nível mais eficiente, como explicitado na seção 'Propósito de quantificar os custos externos'. 
A priori não se sabe se está produzindo ou poluindo de forma eficiente segundo a teoria do bem-estar social. O fato de estudar e quantificar os custos externos de tais atividades produz ferramentas que ajudam a descobrir ou estimar este cenário, isto é, a descobrir em qual ponto da curva a sociedade se encontra. Desta forma, permite diminuir as incertezas.

Não calcular os custos externos, ou apenas ignorá-los de forma completa, representa uma incerteza absoluta em relação ao ótimo alocativo do ponto de vista social. Um exemplo de caso extremo é se produzir para consumo um produto altamente tóxico e ignorar ou desconhecer os efeitos negativos causados por ele. Neste caso, os custos externos negativos relacionados a esta atividade podem superar em muito os benefícios. Observe que ignorar ou desconhecer este efeito negativo (representado pelo custo externo), significa manter uma atividade produtiva altamente prejudicial à sociedade.

Idealmente, o ponto alocativo ótimo corresponde ao ponto onde os custos marginais de abatimento de emissão de partículas (custos em se diminuir uma unidade de emissão) são iguais aos custos externos marginais de emissão, conforme representa a curva abaixo (Figura 3.13). A quantidade 'Qi' corresponde ao ponto ótimo social em relação à emissão do poluente. Já a quantidade 'Qs' é um ponto que representa a situação real, supostamente.

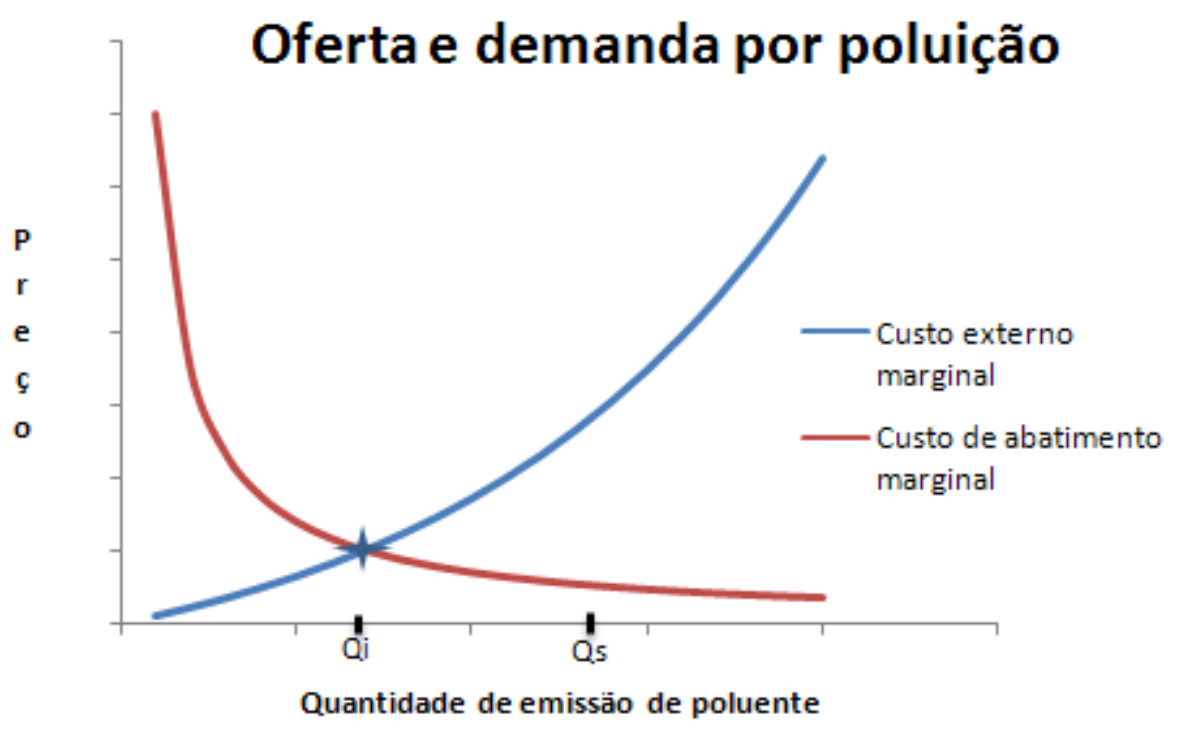

Figura 3.13 - Curvas ilustrativas de oferta e demanda de poluentes.

Observe que quantificar os custos externos é encontrar a curva de oferta por poluição e a demanda é representada pelos custos de abatimento. No entanto, a poluição não é, comumente, um bem sujeito às regras de mercado. Desta forma, não há incentivo ou 
tendência de se trabalhar no ponto ótimo social. Em tese, a quantidade de poluente emitida na realidade pode ser qualquer uma, inclusive a quantidade ótima.

O fato de conhecer os custos externos e fazer com que eles sejam cobrados dos próprios emissores cria a tendência da poluição se comportar segundo as regras de mercado, tendendo à quantidade ótima emitida. Hipoteticamente, se a quantidade emitida é 'Qs' e os emissores pagarem pelos custos externos gerados, a tendência é que as empresas diminuam as emissões pois o custo de arcar com as externalidades (custos externos) são maiores que os custos para diminuir a emissão (custos de abatimento).

Apesar dos custos externos serem estimados e não corresponderem necessariamente aos custos reais, a tendência no longo prazo os custos externos estimados se aproximarem dos custos reais, como resultado do avanço nas pesquisas e técnicas.

Na prática, o ponto ótimo de emissão não é conhecido, têm-se apenas uma idéia. O que ocorre, então, é um processo iterativo. Felizmente parece haver uma tolerância de erros grande na determinação do ponto de emissão ótimo, como mostrado por Rabs, Spadaro e van der Zwaan (2005), e mesmo uma estimação inicial basta para o propósito de calcular os custos do ExternE.

\subsection{ABORDAGEM MULTICRITÉRIO DOS IMPACTOS DA GERAÇÃO}

\subsubsection{CONSIDERAÇÕES INICIAIS}

Como já mencionado, existem basicamente duas formas de abordar os impactos da geração de energia elétrica, a abordagem quantitativa (custos externos) e a multicritério. A abordagem quantitativa, vista anteriormente, tenta valorar todos os impactos externos relevantes expressos num custo externo único, referente à soma dos danos externos causados. Já abordagem multicritério, que será detalhada a seguir, não tenta valorar os impactos em termos monetários, mas em tenta agregar estes impactos ou categorias deles em critérios. E a partir destes critérios são dadas respectivas notas para as alternativas quanto aos critérios, em que a soma das notas parciais, de cada critério, compõem a nota final da alternativa analisada, por exemplo. Dessa forma, as alternativas podem ser comparadas de modo objetivo, em função da nota final.

Os métodos de avaliação multicritérios são aplicáveis a praticamente quaisquer processos decisórios, e, portanto, não são exclusivos para a análise dos tipos de geração de eletricidade. São aplicações muito comuns das avaliações multicritério, a medição de 
desempenho ou a decisão entre alternativas. Muitas vezes os dados não estão disponíveis, acessíveis ou estruturados na forma ideal para consolidação, o que dificulta a escolha da melhor opção feita de maneira intuitiva ou com contas simples. Além disto, há também os aspectos subjetivos a serem considerados, cujas medições são ainda mais complexas, exatamente por serem de caráter pessoal e de difícil externalização.

Diante de situações onde estão envolvidas muitas variáveis associadas a incertezas, o método multicritério, por meio de análises qualitativas, se mostra mais adequado que o método quantitativo. Como exemplo disto, entre os impactos da geração existem alguns especialmente difíceis de lidar, como a eutrofização e a acidificação nos ecossistemas. Elas são de difícil quantificação monetária. Já a contabilização delas por meio da abordagem multicritério, fornece resultados relativamente rápidos e interessantes que traduzem o valor que estas questões têm na mente avaliadores, como mostra o (ExternE-Pol, 2004).

Apesar da quantidade de diversas variáveis objetivas ou subjetivas possíveis envolvidas num processo decisório (ex. custos, percepção, quantidades, produtividade, ambiente, cultura, tempo, etc.), alguns autores afirmam que simplificar a medição é a melhor solução. Defendem, também, que todas as medidas são imperfeitas e que não é necessário medir mais, porém apenas encontrar uma forma que traduza o que realmente importa e que conduza a um plano de ação eficiente.

Esta seção que trata da abordagem multicritério é estruturada da seguinte forma. Inicialmente são apresentados os elementos estruturais comuns das análises multicritérios e aspectos importantes na construção de uma metodologia multicritério de análise. Mais adiante são apresentados os procedimentos, ou etapas, com estrutura sistematizada e inteligente para realizar a análise multicritério. Na seção 3.7.4, são distinguidas duas categorias principais de métodos multicritérios, entre os diferentes tipos de métodos: Teoria do valor Multi-atributo e o método Outranking. Já na seção seguinte são apresentados os principais métodos para eleger pesos aos critérios, como o método Swing e o AHP. E, por último, é feita uma comparação entre os métodos multicritérios.

\subsubsection{HISTÓRICO E ESTRUTURA DA ANÁLISE MULTICRITÉRIO}

Nos últimos trinta anos houve um desenvolvimento muito grande dos métodos de avaliação multicritério, em parte devido à simplicidade desta abordagem frente a problemas complexos atuais; e em parte devido à necessidade de agregar numa avaliação 
diferentes aspectos, dado que os problemas que envolvem diferentes avaliações entre critérios não são solucionados satisfatoriamente com a intuição apenas. Muitos métodos multicritérios estão disponíveis para aplicação em grande variedade de situações onde haja processos decisórios. Além disso, uma série de técnicas para eleger pesos (critérios) foram desenvolvidas, como forma de articular as preferências (ExternE-Pol, 2004).

\section{ELEMENTOS ESTRUTURAIS}

Apesar de existirem muitos métodos distintos, podem ser identificados elementos estruturais comuns entre eles. Tais elementos estruturais ajudam a conceber a avaliação multicritério de forma coerente e sistemática. Uma das estruturas mais convenientes é a lista de checagem CAUSE que é a abreviação de 'Criteria, Alternatives, Uncertainty, Stateholders, Enviroment' (ExternE-Pol, 2004).

\section{CRITÉRIOS}

Critérios representam aspectos, considerados relevantes pelo tomador de decisão, com os quais são feitas comparações. Existem duas formas de construir um problema multicritério: a top-down, que utiliza uma estrutura hierárquica, onde são definidos objetivos principais que se segmentam até os critérios específicos; e a bottom-up, onde os critérios são escolhidos por um processo sistemático e depois são agrupados em categorias mais amplas. Nos dois casos, os critérios devem ter as seguintes propriedades:

- Relevância: os critérios devem abranger os objetivos fundamentais estabelecidos pelos tomadores de decisão, possibilitando que sejam especificadas suas preferências;

- Clareza: o conceito por trás de cada critério deve estar claro, e deve existir a uma direção preferencial clara com relação ao desempenho das alternativas;

- Abrangência: o conjunto de critérios devem abranger todos os aspectos importantes, e ao mesmo tempo serem concisos e operacionais;

- Não-redundância: nenhum critério deve abranger o mesmo conceito que outro, para evitar a redundância e a supervalorização de um critério.

\section{ALTERNATIVAS}

As alternativas são os objetos da análise multicritério. Elas podem ser oferecidas como dados externos à análise multicritério ou podem ser construídas por uma exploração sistemática dos objetivos perseguidos no tipo de decisão considerada. A construção de 
alternativas envolve a criatividade em gerar alternativas interessantes com base nos valores considerados importantes pelas pessoas. No caso de muitas alternativas, o primeiro passo é identificar um conjunto menor de alternativas que representam bem todas as alternativas.

\section{TOMADORES DE DECISÃO}

Os tomadores de decisão são os responsáveis por tomarem as decisões finais. Estão envolvidos no processo decisório onde é identificada a natureza do problema e são os responsáveis por conduzir os procedimentos às direções preferidas.

\section{INCERTEZAS}

As incertezas estão inseridas no processo de decisão e podem ser tanto externas quanto internas. A maior causa de incertezas é o conhecimento limitado sobre os parâmetros externos que podem influenciar o desempenho das ações. Já as incertezas internas surgem dos tomadores de decisão na análise multicritério e são derivadas na estruturação do problema (quais alternativas, quão importante é este critério, etc). As incertezas devem, de forma geral, estar expostas e claras no processo decisório, e não devem ser acobertadas ou ignoradas.

\section{CONTEXTO DA DECISÃO}

O local e os aspectos culturais ou legislativos compõem uma grande influência no processo de decisão. Mesmo considerando elementos iguais, um mesmo procedimento pode ter soluções diferentes se ocorridos em tempo e(ou) local diferentes. Pode ser observado que a análise multicritério não é uma ferramenta que fornece a 'melhor' solução, em termos absolutos para o problema. A solução alcançada só pode ser considerada a melhor para o conjunto de tomadores de decisão que participaram da análise, se outros tomadores de decisão participassem, outra solução poderia aparecer. Não há nada de errado em considerar a análise multicritério como imperfeita ou incapaz de fornecer a 'melhor' solução, pois tal solução não existe, ela depende das necessidades e das condições do ambiente.

\subsubsection{PROCEDIMENTOS DA ANÁLISE MULTICRITÉRIO}

Da confecção de uma análise multicritério aos resultados finais que podem obtidos por ela, alguns procedimentos organizados de forma sistemática e inteligente podem ser sugeridos para que se obtenha sucesso na análise e ou decisão. De acordo ExternE-POL, os 
procedimentos estão dispostos conforme mostra o diagrama a seguir. Esta estrutura permite a construção de uma análise multicritério de maneira coerente.

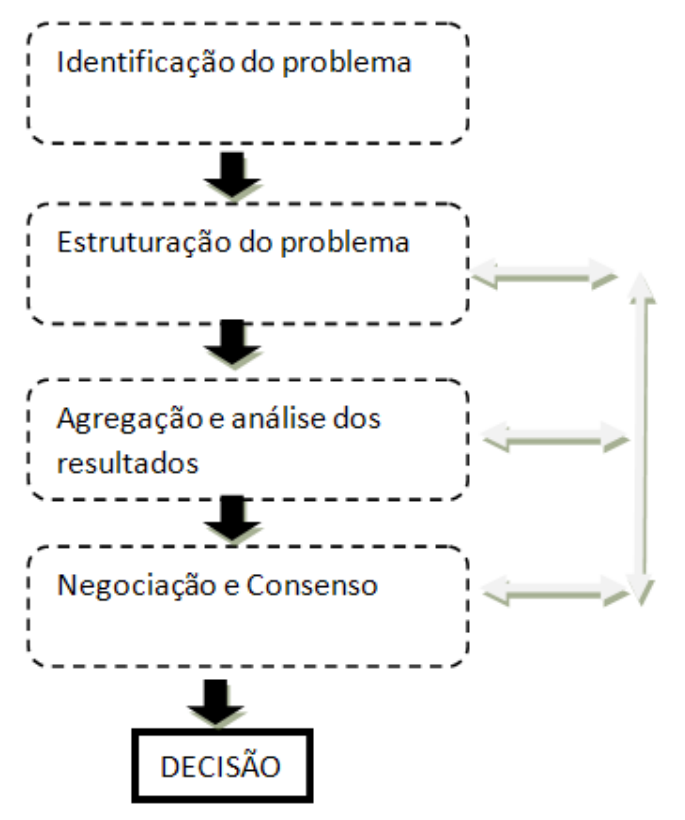

Figura 3.15 - Passos na análise multicritério

\subsubsection{FORMAS DE ELEGER E AGRUPAR PREFERÊNCIAS}

Existem diferentes métodos multicritérios, no entanto as suas diferenças concentram principalmente na forma de eleger preferências e agregá-las. Quanto a este aspecto pode-se dividir os métodos em duas categorias:

- Teoria do Valor Multi-Atributo (TVMA), chamada de Multi-Attribute Value Theory (MAVT) (ExternE-Pol, 2004): a TVMA objetiva associar um único número ou valor que representa cada alternativa de forma geral, levando em conta todos os critérios. No início são um valor parcial ou peso é atribuído em para cada critério entre 0 e 1 , onde a soma dos pesos é igual a 1 . Dependendo do processo com o qual os pesos são atribuídos, estes podem ser a síntese das importâncias relativas atribuídas de um critério sobre o outro, como no caso das 'Analitic Hierarchy Process'(AHP). De forma geral, os pesos representam a importância relativa de cada critério para o resultado final. O modelo mais simples e usado de agregar os critérios é por adição:

$$
v(a)=\sum_{i} w i \times v i(a)
$$

Onde V(a) é o valor total associado a cada alternativa a, e $\mathbf{W}_{\mathbf{i}}$ é o peso correspondente a cada critério $\mathbf{i}$. 
Finalmente, os valores referentes às notas de cada alternativa $(\mathrm{V}(\mathrm{a}))$ são ordenados para a classificação

- Método Outranking, começa com comparação em pares das alternativas para cada critério resultando numa relação binária, por exemplo: 'a alternativa a é melhor que

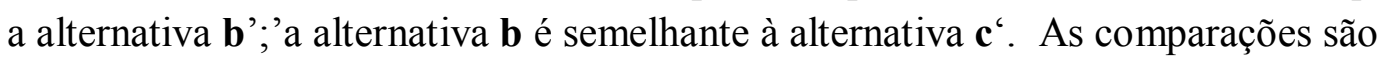
feitas entre dados das alternativas. Especialmente, este método julga quanto à indiferença entre as alternativas com relação ao critério, esta indiferença é expressa por uma faixa ou valor limite. Por exemplo: 'Se $g(a)>g(b)+$ cte $\rightarrow D(a, b)=0$ (a melhor ou pior que $b)$; Se $g(b)>g(a)+c t e ~ \rightarrow D(a, b)=1$; Caso contrário $\rightarrow$.... '. Observe que, diferentemente do TVMA, no método outranking os pesos ou valores resultantes não representam a rigor uma relação de compromisso entre os critérios, já que eles são usados para comparar a preferência. Estes pesos ou valores são uma medida resultante das relações entre cada critério, sujeitas aos resultados da comparação. Os resultados também são apresentados normalmente em forma de classificação do maior valor para o menor.

\subsubsection{MÉTODOS PARA ELEGER PESOS}

Existem basicamente duas categorias de métodos para eleger pesos para os critérios, que são: os compensatórios e os não-compensatórios. O termo compensatório faz referência à possibilidade de compensação entre os critérios, explicitado na forma de valores. Observase que existe uma compensação clara entre os critérios nos métodos TVMA.

Os métodos compensatórios mais usados para eleger pesos são os seguintes:

\section{Método TRADE-OFF}

O método TRADE-OFF é baseado numa base teórica rígida e revela os dilemas dos tomadores de decisão por meio de uma comparação de critérios em pares. Em cada par, duas situações hipotéticas são construídas para apenas estes dois critérios. A primeira alternativa tem a melhor performance em um critério e a pior no segundo critério, enquanto a performance oposta é esperada para a segunda alternativa. Os tomadores de decisão são questionados quanto à alternativa preferida, e por meio de um conjunto de comparações é definido o critério mais importante. O segundo passo, é definir o quanto os tomadores de decisão estão dispostos a abrir mão do melhor critério para levar outros critérios para o melhor nível. Estas respostas revelam diretamente a relação de compromisso entre os critérios (ExternE-Pol, 2004).

\section{Método SWING}


O método SWING se inicia com a construção de dois cenários hipotéticos extremos, o $\mathrm{P}$ e o $\mathrm{M}$, onde o primeiro é composto pelo conjunto de todos os piores cenários de cada critério, já o ultimo é composto pelos melhores cenários em cada critério. O procedimento de determinar as preferências consiste em pedir ao tomador de decisão para observar cuidadosamente os potenciais ganhos em se mover do cenário $\mathrm{P}$ para o $\mathrm{M}$, e em seguida decidir qual o primeiro critério que ele preferiria mover do cenário P para o M. Assumindo que esta primeira troca tem o valor de 100 unidades numa escala hipotética, o tomador de decisão é solicitado a atribuir outro valor hipotético $(<100)$ ao segundo critério movido para o cenário $\mathrm{M}$, em ordem de importância. Da mesma forma acontece para o terceiro critério mais importante, e assim por diante até percorrer todos os critérios. Desta forma, são definidos os pesos de cada critério (ExternE-Pol, 2004).

\section{RESISTANCE TO CHANGE}

Este método é baseado na Teoria de Construção Pessoal (Personal Construct Theory) e recentemente tem sido adaptada para estimar a importância relativa dos critérios ambientais nos métodos Outranking. Este método possui elementos do método SWING assim como elementos das técnicas de comparação em pares. Para cada critério são supostos dois pólos de desempenho, uma desejável (melhor) e outra indesejável (pior). Assumindo que em princípio todos os critérios estão no lado desejável, é pedido ao tomador de decisão para comparar todos os critérios em pares e escolher qual dos dois ele estaria disposto a mover para o lado indesejável. A importância relativa de cada critério é definida pelo número de vezes em se resistiu mudar cada critério durante o processo de comparação (ExternE-Pol).

MACBETH (Measuring Attractiveness by a Categorical Based Evaluation Technique) $M A C B E T H$ é um método TVMA que integra o processo de escolha do peso como uma parte essencial da avaliação geral. Este método contém elementos dos métodos SWING e TRADE-OFF, enquanto as comparações incluem pontuações caracterizadas por serem neutras ou positivas. É feito um teste de consistência para testar a coerência do processo (ExternE-Pol, 2004).

\section{Estimativa holística (HOLISTIC approach)}

Os tomadores de decisão são pedidos para examinar alternativas levando em conta todo o conjunto de critérios e atribuir um valor a cada alternativa. As preferências holísticas são 
então encontradas por meio de regressão estatística para encontrar as funções únicas e os correspondentes pesos de cada critério. Do ponto de vista do tomador de decisão este método é bastante conveniente, no sentido de facilitar seu trabalho. No entanto, as pessoas têm a tendência de ignorar ou interpretar de forma errada muitos atributos, enquanto avaliam as alternativas. Este método não força o tomador de decisão estar consciente de suas próprias preferências, o que é um tanto questionável negativamente (ExternE-Pol, 2004).

Método AHP (Analitic Hierarchy Process)

Esse método estabelece os pesos dos critérios por meio de comparações em pares entre cada critério. O tomador de decisão é questionado em cada comparação quanto à preferência de um critério sobre o outro, esta preferência deve ser expressa em um número de 1 a 9, segundo a escala proposta por Saaty, 1991. onde o número 1 indica mesma importância e o número 9 indica importância absoluta. As comparações recíprocas são assumidas com o inverso da comparação direta. Desta forma é montada uma matriz de comparações com os respectivos valores em cada elemento. Por meio de um teste a matriz é considerada consistente ou não, isto é, há coerência entre os valores atribuídos ou não. Finalmente, os pesos de cada critério são atribuídos pela seguinte fórmula:

$$
W_{i}=\sqrt[n]{\prod_{j=1}^{n} a_{i j}}
$$

Onde $\mathbf{i}$ e $\mathbf{j}$ correspondem respectivamente ao número da linha e coluna, e $\mathbf{n}$ é igual à dimensão da matriz quadrada (número de critérios).

\subsubsection{COMPARAÇÃO ENTRE OS MÉTODOS MULTICRÍTERIOS}

Algumas propriedades têm destes métodos podem influenciar a capacidade de traduzir as preferências humanas em valores numéricos. São elas:

- Simplicidade e transparência;

- Graus de inconsistência na articulação das preferências; e

- Habilidade de lidar com um pequeno ou grande número de critérios; 
$\mathrm{O}$ quadro a seguir apresenta um comparativo entre os métodos aplicados em relação às propriedades citadas acima.

Tabela 3.3 - Comparação entre os métodos baseada na avaliação do ExternE-Pol (Análise Multicritério)

\begin{tabular}{|c|c|c|c|}
\hline $\begin{array}{c}\text { Método } \\
\text { multicritério }\end{array}$ & Simplicidade & $\begin{array}{c}\text { Inconsistência na } \\
\text { articulação das } \\
\text { preferências }\end{array}$ & $\begin{array}{c}\text { Habilidade de lidar } \\
\text { com grande número } \\
\text { de critérios }\end{array}$ \\
\hline TRADE-OFF & Complicado & $\begin{array}{l}\text { Alta inconsistência (pode } \\
\text { parecer confuso) }\end{array}$ & $\begin{array}{l}\text { Dificuldade de lidar } \\
\text { com muitos critérios }\end{array}$ \\
\hline SWING & Simples & $\begin{array}{l}\text { De pequena a média } \\
\text { inconsistência }\end{array}$ & $\begin{array}{l}\text { Grande facilidade } \\
\text { relativa em lidar com } \\
\text { muitos critérios }\end{array}$ \\
\hline $\begin{array}{l}\text { RESISTANCE } \\
\text { TO CHANGE }\end{array}$ & Complicado & Pequena inconsistência & $\begin{array}{l}\text { Dificuldade de lidar } \\
\text { com muitos critérios }\end{array}$ \\
\hline МАСВЕТН & Complicado & $\begin{array}{l}\text { Alta inconsistência (pode } \\
\text { parecer confuso) }\end{array}$ & $\begin{array}{l}\text { Dificuldade de lidar } \\
\text { com muitos critérios }\end{array}$ \\
\hline $\begin{array}{l}\text { Estimativa } \\
\text { Holística }\end{array}$ & O mais simples & $\begin{array}{l}\text { Alta inconsistência } \\
\text { (tendência de haver } \\
\text { negligência na avaliação) }\end{array}$ & $\begin{array}{l}\text { Facilidade } \\
\text { acompanhada de } \\
\text { probabilidade } \\
\text { crescente de } \\
\text { inconsistências }\end{array}$ \\
\hline AHP & $\begin{array}{l}\text { Média } \\
\text { simplicidade }\end{array}$ & Baixa inconsistência & $\begin{array}{l}\text { Dificuldade de lidar } \\
\text { com muitos critérios }\end{array}$ \\
\hline
\end{tabular}

O método Swing é destacado pelo ExternE-Pol como o mais adequado, em função das seguintes vantagens comparativas: é método o mais simples e transparente; o melhor em evitar inconsistências; e aplicável praticamente em qualquer número de critérios.

\subsubsection{CONSIDERAÇÕES FINAIS SOBRE MÉTODOS MULTICRITÉRIOS}

Foram apresentados na abordagem multicritério, os elementos estruturais e os aspectos relevantes na construção de uma análise multicritério, assim como os procedimentos que envolvem tal construção. Um panorama dos principais métodos multicritérios também foi 
descrito assim como as suas principais classificações. Constituindo uma base teórica abrangente para a construção de um modelo multicritério.

Os métodos foram comparados entre si em relação à sua simplicidade, consistência e habilidade para lidar com um grande número de critérios. O método considerado mais favorável foi o método Swing.

\subsection{CONSIDERAÇÕES FINAIS}

A partir dos aspectos conceituais dos impactos ambientais e sociais e o tema externalidade foi possível contextualizar a geração de energia com seus principais efeitos.

Foi visto que as externalidades podem ser negativas ou positivas e se originarem no consumo ou na produção. Também foi visto que falhas de mercado, ou ineficiências alocativas, são geradas pela existência de externalidades nas atividades humanas. Dessa forma, tais externalidades devem ser levadas em consideração pela atividade em questão. Os problemas gerados pelas externalidades têm diferentes tipos de soluções, tanto privadas quanto públicas, com destaque para a comercialização de permissões, que é uma política pública baseada no mercado. Foi visto também que não existe uma solução adequada para todos os casos; a determinação da melhor política depende, consequentemente, da natureza da incerteza, do comportamento das curvas de custo para o setor em questão e da disponibilidade e qualidade das informações para se caracterizar o custo externo (Prado, 2007).

$\mathrm{Na}$ seção 3.5 foram apresentados aspectos básicos da abordagem quantitativa como a metodologia Impact Pathway Approach e os principais tipos de impactos causados pelas indústrias de geração de energia elétrica incluindo os danos ambientais e à saúde humana. Como mostrado, a quantificação dos custos externo pode contribuir para a sociedade em diversas aplicações no sentido de balizar as atividades humanas em questão, para um nível mais eficiente.

Já a abordagem multicritério foi apresentada na seção 3.6 com seus elementos estruturais e as etapas básicas para a formulação de uma análise multicritério. Dentre os métodos multicritérios apresentados o método Swing foi selecionado como o mais adequado em função das suas vantagens comparativas. 
Foi possível, a partir do estudo feito neste capítulo, concluir que a abordagem quantitativa (custos externos) não é adequada para incluir os impactos sociais e ambientais referentes à geração de energia elétrica para comunidades isoladas. Os motivos são:

- Os custos sociais (como por exemplo: o custo do êxodo para as cidades próximas) são de difícil quantificação e valoração;

- As externalidades, segundo seus princípios, não contabilizam os impactos chamados sociais internos, envolvendo os produtores e consumidores de energia. Logo, não é adequado incluir muitos dos impactos sociais como custos externos;

- Para quantificar os impactos em termos monetários é necessária uma base de dados ampla e confiável envolvendo os impactos causados e os seus respectivos custos, que não existe no Brasil;

- Os impactos sociais e ambientais dependem do local considerado, não permitindo uma padronização.

Dessa forma, considera-se a abordagem multicritério como a alternativa mais adequada para incluir os aspectos sociais e ambientais no processo de decisão do tipo de geração em comunidades isoladas. Como vantagem direta desse tipo de abordagem, destaca-se a grande flexibilidade para contabilizar aspectos diversos no processo decisório. Segundo a análise dos métodos multicritérios, foi concluído que o método Swing apresenta as características mais desejáveis para construção de uma análise multicritério que contenha os diferentes aspectos sociais e ambientais, revelando-se mais pertinente para o caso específico de comunidades isoladas. 


\section{METODOLOGIA MULTICRITÉRIO APLICADA ÀS COMUNIDADES ISOLADAS}

\subsection{CONSIDERAÇÕES INICIAIS}

A partir do estudo da problemática do fornecimento de energia às comunidades isoladas (explicitados no capítulo 2) e das abordagens dos impactos existentes na literatura (capítulo 3), foi possível definir uma metodologia que buscasse inserir os aspectos ambientais e sociais no processo decisório das alternativas de geração apropriada às comunidades isoladas no Brasil.

A metodologia considerada mais apropriada para avaliar as alternativas utiliza a abordagem multicritério. Em especial, o método Swing foi considerado o parâmetro a ser seguido por esta metodologia.

Apesar desta metodologia se basear no método Swing, mistura julgamentos subjetivos das alternativas aos dois cenários extremos criados. O método AHP também está incluído nesta metodologia como forma complementar para eleger os pesos (medida de importância) correspondentes aos critérios desenvolvidos.

\section{ESTRUTURA DO CAPÍTULO}

Este capítulo se inicia com as etapas inicias propostas pelo ExternE-Pol, a fim de seguir os procedimentos considerados eficientes para construção de uma análise multicritério, que envolvem a identificação e a estruturação do problema. Após estes passos iniciais é apresentada a estrutura do programa multicritério (seção 4.3).

A seção 4.3 introduz, inicialmente, os aspectos básicos do programa multicritério proposto e sua estrutura básica, envolvendo duas formas de avaliação: a objetiva e a subjetiva, além dos critérios eliminatórios e os classificatórios. Em seguida, são apresentados os critérios eliminatórios propostos, deixando margem à flexibilidade e aos ajustes de acordo com a necessidade. Mais adiante são descritos os critérios classificatórios elaborados, especialmente, para atender as necessidades pertinentes às comunidades isoladas. Cada critério é explicado quanto ao seu tipo (objetivo ou subjetivo) e à finalidade de sua inclusão e são definidos os aspectos que devem ser observados para a correta avaliação dos projetos de geração em função dos critérios. 
Na seção 4.6, são descritas as duas opções oferecidas para eleger os pesos ou prioridades dos critérios classificatórios: os métodos Swing e AHP.

Nas seções 4.7 e 4.8 são apresentadas as etapas necessárias para concretizar a avaliação multicritério. São apresentadas, inicialmente, as etapas que os avaliadores devem seguir na avaliação multicritério, proporcionada pelo aplicativo em Excel. Na seção 4.8 são apresentadas algumas sugestões de etapas a serem seguidas pela instituição que vier a utilizar o programa multicritério aqui proposto.

\subsection{ETAPAS INICIAIS PARA A CRIAÇÃO DA AVALIAÇÃO MULTICRITÉRIO}

\subsubsection{IDENTIFICAÇÃO DO PROBLEMA}

Objetiva-se avaliar projetos de geração de energia elétrica para comunidades isoladas ou pequenas sistemas isolados considerando outros aspectos além do econômico, com base em diferentes critérios. Pretende-se formular uma metodologia que seja criteriosa e ao mesmo tempo objetiva. Como já explicado, foi escolhida a análise múlticritério para tal tarefa, pois a análise quantitativa ou monetária de todos os aspectos ou impactos da geração e a sua inserção na análise econômico-financeira são inviáveis nos casos de comunidades isoladas.

Tem-se, dessa forma, o propósito de construir uma ferramenta de apoio à decisão que englobe aspectos distintos dos empregados na análise puramente financeira. E, por essa razão, devem ser consideradas questões ambientais, sociais e técnicas. A grande motivação da inserção de questões ambientais como critérios relevantes é a construção de um mundo ambientalmente mais sustentável e possibilitar este tipo de desenvolvimento nas comunidades isoladas. Os critérios sociais devem atender os impactos da tecnologia na melhoria de saúde, da educação, da produtividade e a sinergia com os processos produtivos da comunidade. Já as questões técnicas devem contemplar, principalmente, a operacionalidade, facilidade, confiabilidade e manutenção do sistema de geração, pois estas questões são críticas quando o local é geograficamente isolado, o que dificulta muitíssimo as visitas técnicas para reparos.

Um desafio é expressar questões consideradas importantes em dados objetivos, em face da dificuldade em obtê-los. Também, não se deve engessar a avaliação multicritério com uma grande gama de variáveis difíceis de serem obtidas. 
Este programa pretende apoiar a decisão sobre projetos de investimentos sociais para a geração de eletricidade em comunidades isoladas, orientando a aplicação de recursos financeiros com base em uma série de critérios. O público-alvo desta metodologia são o Estado e as instituições privadas com interesse em financiar investimentos sociais com vistas à universalização do fornecimento de energia elétrica.

\subsubsection{ESTRUTURAÇÃO DO PROBLEMA}

Podem ser identificadas quatro categorias de impactos a serem avaliados:

- Econômica: deve englobar critérios que indiquem eficiência econômica do projeto.

- Social: devem envolver questões como a adaptação das comunidades e das regiões à tecnologia de geração de eletricidade, a sinergia entre a comunidade e a tecnologia, a facilidade de aumento da oferta de energia do sistema (em um eventual aumento da demanda), a facilidade de operação do sistema para os moradores locais, a relação entre o combustível usado e a sua disponibilidade regional, e a relação entre a atividade produtiva local e o tipo de geração. Em suma, esta categoria de critérios pretende abranger os benefícios do tipo de geração do ponto de vista da comunidade que recebe o serviço.

- Ambiental: deve abranger questões como poluição atmosférica, da água, do solo e o aquecimento global. Pretende discorrer sobre aspectos ambientais considerados clássicos.

- Técnica: deve conter critérios que avaliem a confiabilidade e a disponibilidade do serviço, a operação e a manutenção do sistema gerador, a necessidade de gerenciamento pelo lado da demanda (adaptação da curva de carga ao modo de funcionamento do sistema de geração). A eficiência do ponto de vista técnico como $\mathrm{kWh} /$ ano também deve ser considerada

Para garantir que a comparação entre os projetos seja minimamente coerente, faz-se necessário que alguns critérios eliminatórios sejam elaborados. Inicialmente, pensou-se em restringir projetos com base no valor presente do projeto (só poderão ser comparados projetos que se situem numa mesma faixa de valor) e com base em um mínimo de $\mathrm{kWh}$ gerado por ano, suficientes para atender à demanda local estimada (atende sua carga estimada?). Desta forma, os critérios serão de dois tipos: eliminatório ou classificatório. O critério eliminatório tem a função de restringir o escopo de projetos concorrentes e garantir que atendam as necessidades básicas definidas pela instituição a frente do processo de avaliação multicritério. Já os critérios classificatórios são responsáveis por compor a avaliação das alternativas de geração. 


\subsection{ESTRUTURA DO PROGRAMA MULTICRITÉRIO}

\subsubsection{INTRODUÇÃO}

O programa multicritério - Avaliação Multicritério para Geração em Comunidades Isoladas - tem uma estrutura baseada em critérios objetivos e subjetivos, além dos critérios eliminatórios e dos classificatórios tendo por base, principalmente, o Método Swing modificado, que será explicado mais adiante.

Este programa foi implementado em programação Visual Basic for Aplications (VBA) no Excel® 2007. O aplicativo fornece a estrutura necessária para que sejam avaliados os projetos, sejam eleitas as preferências do avaliador e para que seja lançada a classificação final dos projetos de geração de eletricidade, de acordo com a nota final de cada projeto.

Os critérios objetivos, citados acima, são aqueles analisados objetivamente por meio dos dados de cada projeto de geração, onde o pior e o melhor cenário neste quesito balizam a nota (método Swing). Já os critérios subjetivos, estão sujeitos à livre análise do avaliador/especialista sobre o critério em questão, de acordo com seu conhecimento sobre o assunto. No entanto, neste capítulo são fornecidas referências para a avaliação subjetiva, onde são apresentados exemplos de tipo de classificação das tecnologias de geração com base nos critérios em questão.

Paralelamente, são definidas outras duas categorias de critérios: os eliminatórios e classificatórios. Os eliminatórios são critérios críticos capazes de classificar ou desclassificar o projeto de geração. Já os classificatórios, são responsáveis pela nota avaliada (final) de cada projeto. Esta nota varia de 0 a 100, onde a nota máxima representa a melhor classificação possível.

Cada critério classificatório recebe um peso proporcional à sua importância, segundo a perspectiva do avaliador, onde a soma das prioridades resultantes dos critérios é igual a $100 \%$. Para eleger as prioridades de cada critério, o avaliador tem a flexibilidade de escolher dois diferentes métodos: o método Swing (pesos) ou o método AHP (matriz de comparações), que serão detalhados mais adiante. A possibilidade de optar entre duas formas de eleição dos pesos dos critérios, visa proporcionar maior confiabilidade à análise e conferir flexibilidade ao avaliador na escolha do método em que melhor se adapta.

\subsubsection{AVALIAÇÃO DOS CRITÉRIOS}

A avaliação dos critérios é divida em dois tipos: objetiva e subjetiva, mostrados a seguir. 


\subsubsection{AVALIAÇÃO OBJETIVA}

Os critérios que apresentam dados concretos (por exemplo: custo econômico direto) sobre o projeto ou alternativa de geração de eletricidade serão analisados de forma objetiva. A maneira objetiva de avaliação, nesta proposta, faz uso de um recurso do método SWING, que é a construção de dois cenários, $\mathrm{M}$ e $\mathrm{P}$, onde $\mathrm{M}$ representa o cenário com o conjunto dos melhores índices em cada critério e o cenário $\mathrm{P}$ representa o conjunto dos piores índices em cada critério.

Cada critério objetivo terá um conjunto de índices (exemplo: emissão de $\mathrm{tCO}_{2 \mathrm{eq}} / \mathrm{kWh}$ ), entre os quais haverá o melhor e o pior. O melhor será avaliado com a nota máxima: dez. O pior será avaliado com a nota mínima: zero. Os índices com valores intermediários serão avaliados de maneira linear, onde o índice que se encontra exatamente no meio, entre o maior e o pior índice, será avaliado com a nota cinco.

\subsubsection{AVALIAÇÃO SUBJETIVA}

Caso o critério não aceite dados objetivos que permitam sua avaliação, ou seja, é um critério subjetivo por natureza, deve-se utilizar a avaliação subjetiva. Na hipótese do critério ser objetivo, mas não esteja disponível um conjunto de dados, como solução devese utilizar a avaliação subjetiva.

A avaliação subjetiva deve contemplar o conhecimento prévio dos avaliadores/especialistas sobre o assunto tratado no critério. As informações e os dados relativos às tecnologias de geração de eletricidade usadas em cada alternativa, devem ser utilizados como referência para atribuir a nota da alternativa quanto ao critério em questão.

Em tese, cada projeto de geração é único e por isso devem ser utilizar informações e dados do projeto, para sua avaliação. No entanto, são aceitos pressupostos baseados no conhecimento prévio e na experiência dos avaliadores sobre a relação entre o tipo de tecnologia e o assunto tratado pelo critério, como a emissão típica de dióxido de carbono e determinada tecnologia, entre outras.

Para padronizar e facilitar a atribuição de notas a cada critério, deve-se seguir o padrão adotado na tabela a seguir. Os avaliadores devem escolher as menções, da alternativa em relação ao critério, cuja nota atribuída referente a cada menção está mostrada na tabela a seguir. 
Tabela 4.2 - Padrão de avaliação dos critérios subjetivos.

\begin{tabular}{cc}
\hline Classificação da alternativa aos critérios qualitativos \\
\hline MENÇÃO & NOTA \\
Muito Bom & 10 \\
Bom & 7 \\
Regular & 5 \\
Ruim & 3 \\
Muito Ruim & 0 \\
\hline
\end{tabular}

\subsection{CRITÉRIOS ELIMINATÓRIOS}

Os critérios eliminatórios sugeridos, capazes de desqualificar o projeto ou alternativa de geração, são definidos a seguir:

1) Valor Presente

Os projetos devem estar numa mesma faixa de valor monetário. $\mathrm{O}$ valor presente do projeto deve se situar na faixa $\mathrm{VP}_{\min }<\mathrm{VP}<\mathrm{VP}_{\max }$.

2) Energia anual demandada mínima

A quantidade de $\mathrm{kWh} /$ ano deve ser no mínimo igual à Energia demandada mínima em um ano para a comunidade isolada.

3) Viabilidade da alternativa de geração

A tecnologia utilizada deve ter compatibilidade com a região. Caso não haja condições propícias ao funcionamento da alternativa de geração, o projeto deve ser eliminado (exemplo: aerogeradores em local sem condições de vento mínimas).

Deve ser observado que os limites do valor presente e a energia anual mínima devem ser definidos pela instituição (pública ou privada) responsável por utilizar esta metodologia com interesse em investir uma quantia determinada, que visa financiar um sistema de geração para uma ou mais comunidades isoladas sem eletricidade.

\subsection{CRITÉRIOS CLASSIFICATÓRIOS}

Nesta parte os critérios são explicados e são apresentadas referências para a classificação dos critérios subjetivos. 


\subsubsection{CRITÉRIOS ECONÔMICOS}

\subsubsection{R\$/kWh}

Corresponde a um indicador objetivo de eficiência econômica do projeto. É um dado quantitativo por natureza. A nota para este item deve ser dada segundo o método SWING, onde, dentre as alternativas de projeto, o item com menor $\mathrm{R} \$ / \mathrm{kWh}$ possui nota dez, e o menor recebe nota zero. Já os itens com valor intermediário recebem nota proporcional a escala linear.

\subsubsection{CRITÉRIOS SOCIAIS}

\subsubsection{Sinergia entre a fonte primária energética e as atividades produtivas locais}

Este critério subjetivo é um pouco amplo e aborda a relação complementar entre a geração e as atividades produtivas locais. Entretanto, as relações ou vantagens exclusivas do fornecimento da energia elétrica nas atividades produtivas locais devem ser desconsideradas, pois todas as alternativas de geração são aptas a oferecerem este serviço. Este critério deve tentar contemplar os seguintes aspectos:

- Se os rejeitos da produção local são utilizados de alguma forma na geração;

- Geração de postos de trabalho na geração de energia elétrica, quer seja na extração da fonte primária ou no processo de transformação da fonte primária em insumo energético. Exemplo: o uso da biomassa como combustível na geração (resíduos florestais, cascas de alimentos produzidos) requer a participação de mão-de-obra local; e

- Em geral, o tipo de geração que utiliza a biomassa tem grande sinergia com as atividades produtivas em comunidades na Região Amazônica, principalmente as extrativistas.

\subsubsection{Operação manual do sistema por moradores locais}

A avaliação deste critério é subjetiva por natureza. Para avaliação deste critério devem ser observados os seguintes aspectos:

- Quanto mais fácil e automática a operação do sistema de geração melhor está posicionada a alternativa com relação a este critério;

- A facilidade de operação deve ser compatível com o grau de instrução dos moradores, caso seja muito complexa, a alternativa deve ser penalizada;

- Uma operação complexa pode ser a coordenação do ligamento de muitos equipamentos, em ordem específica, que ocorra em grande freqüência; 
- O sistema que prevê erros de operação e os indica ao operador quando ocorrem são desejáveis e avaliados como positivos;

- Robustez ao erro de operação é desejável, isto é, o sistema de geração não quebra facilmente devido a erros de operação; e,

- Sistemas de geração híbridos têm tendência à operação manual mais complexa, exceto quando automatizados.

\subsubsection{Disponibilidade da fonte de energia no local}

Este é um critério que tenta valorizar as alternativas sustentáveis e que utilizam recursos energéticos disponíveis no local. A sua avaliação é de natureza subjetiva e deve ser classificada observando os seguintes aspectos:

- Quanto mais abundante for a fonte de energia que alimenta a geração na localidade, mais bem classificada ela é. Por exemplo, na geração eólica, quanto maior a constância e a velocidade do vento, melhor classificada ela é em relação a este critério. Quanto ao uso de turbinas hidrocinéticas, deve ser avaliada à abundância de rios com condições mínimas adequadas, a distância entre eles e o centro da comunidade;

- A facilidade com que a fonte primária de energia do local se transforma na fonte de energia pronta (ou combustível) para a geração é um aspecto importante, pois não basta existir abundância de fonte primária de energia no local. Se a fonte de energia primária precisa ser transformada para se tornar útil e este é um processo dificultoso e inacessível localmente, a disponibilidade do insumo energético é pequena. Exemplo: transformação de biomassa em energia elétrica pode ser considerada um processo relativamente dificultoso, dependendo da tecnologia de transformação;

- A dependência da importação do combustível a ser usado é considerada o pior caso para este critério. Exemplo: a importação de óleo diesel para estas comunidades de difícil acesso é considerada bastante negativa neste critério.

\subsubsection{CRITÉRIOS AMBIENTAIS}

\subsubsection{Poluição Atmosférica}

O intuito de incluir este critério é penalizar as alternativas de geração que mais emitam poluentes atmosféricos, e favorecer as que menos poluem. Existe uma grande quantidade de poluentes atmosféricos, entre eles, os cinco principais são: $\mathrm{O}_{3}$ (ozônio de superfície), $\mathrm{SO}_{2}, \mathrm{NO}_{\mathrm{X}}, \mathrm{PM}_{10}$ (partículas com diâmetro menor que $10 \mu \mathrm{m}$ ) e CO. Para uma avaliação mais objetiva, é muito desejável que sejam apresentados dados sobre a emissão destes 
poluentes. Portanto, estabeleceram-se, arbitrariamente, três dados de emissão considerados necessários na avaliação objetiva deste critério. São eles: $\mathrm{SO}_{2}, \mathrm{PM}_{10}$ e $\mathrm{NO}_{\mathrm{X}}$.

Apesar de ser uma escolha arbitrária, os três tipos de poluentes escolhidos podem ser assim justificados. $\mathrm{O} \mathrm{SO}_{2}$ é responsável por uma série de impactos como a diminuição da expectativa de vida; aumento de admissões em hospitais e danos ao meio ambiente por meio das chamadas 'chuvas ácidas'. Já o $\mathrm{NO}_{\mathrm{X}}$ pode causar redução da expectativa de vida, danos às plantações e ao ecossistema, e eutrofização, além de ser o responsável pela formação de $\mathrm{O}_{3}$, que possui uma série de outros possíveis impactos. O $\mathrm{PM}_{10}$ (Particule Matter) é uma denominação que engloba uma série de poluentes (com diâmetro menor que $10 \mu \mathrm{m})$ que podem causar diversos impactos à saúde humana. Os impactos causados por estes poluentes atmosféricos estão resumidos na seção 3.5.5.

A este critério, é prevista flexibilidade quanto ao tipo de avaliação: objetiva ou subjetiva. Caso sejam apresentados dados dos três tipos de emissão citados acima $\left(\mathrm{SO}_{2}, \mathrm{PM}_{10}\right.$ e $\mathrm{NO}_{\mathrm{X}}$ ), para cada alternativa de geração, a avaliação deste critério deverá ser do tipo objetiva, conforme explicado a seguir. No entanto, se não forem disponibilizados os dados dos três tipos de emissão citados, a avaliação deverá ser do tipo subjetiva.

\section{a) Avaliação objetiva da Poluição Atmosférica}

A poluição atmosférica pode ser subdividida em três sub-critérios: taxa de emissão por unidade de tempo do $\mathrm{SO}_{2}, \mathrm{PM}_{10}$ e do $\mathrm{NO}_{\mathrm{X}}$. Foi definido que cada um dos três tipos de emissão têm peso igual na composição da nota do critério 'poluição atmosférica' e os dados de emissão de cada sub-critério serão avaliados de maneira objetiva, explicada anteriormente, onde a maior emissão recebe a nota mínima, zero. Desta forma, a nota final do critério 'poluição atmosférica' é igual à média aritmética das notas individuais dos tipos de emissão.

\section{b) Avaliação subjetiva da Poluição Atmosférica}

Este critério deverá ser avaliado de forma subjetiva quando os dados de emissão forem inexistentes ou incompletos. Para tanto, a avaliação da alternativa de geração deverá ser baseada no conhecimento e experiência dos avaliadores sobre os impactos ambientais causados por determinados tipos de geração, tendo em vista os aspectos contidos no projeto da alternativa de geração. Como sugestão ou referência para a avaliação baseada na 
tecnologia de geração, é apresentada a tabela seguir, que contempla os principais tipos de tecnologias de geração em pequena escala.

Tabela 4.4 - Sugestão para avaliação da poluição ambiental em função da tecnologia

Classificação suģrida quanto à Poluição atmosférica em relação à tecnologia
\begin{tabular}{|c|c|c|c|c|c|}
\hline Fotovoltaica & Hidrocinética & Eólica & Biomassa & Microturbinas & $\begin{array}{c}\text { Gerador a } \\
\text { disel }\end{array}$ \\
\hline Muito baixa & Muito baixa & Muito baixa & Alta & $\begin{array}{c}\text { Depende do } \\
\text { combustível }\end{array}$ & Alta \\
\hline
\end{tabular}

Outra classificação é apresentada na próxima tabela, porém esta se refere ao tipo de combustível utilizado.

Tabela 4.5 - Sugestão para avaliação da poluição ambiental em função da ao combustível

\begin{tabular}{|c|c|c|c|c|c|}
\hline \multicolumn{6}{|c|}{ Classificação sugerida quanto à Poluição atmosférica em relação ao combustível } \\
\hline $\begin{array}{c}\text { Carvão } \\
\text { mineral }\end{array}$ & $\begin{array}{c}\text { Carvão } \\
\text { vegetal ou } \\
\text { lenha }\end{array}$ & $\begin{array}{c}\text { Resíduos } \\
\text { orgânicos } \\
\text { (biomassa) }\end{array}$ & Gás Natural & $\begin{array}{c}\text { Óleo } \\
\text { combustível }\end{array}$ & Óleo diesel \\
\hline Muito alta & Alta & Alta & Baixa & $\begin{array}{c}\text { Alta a Muito } \\
\text { alta }\end{array}$ & Alta \\
\hline
\end{tabular}

\subsubsection{Aquecimento Global}

O critério 'Aquecimento global' é incluído na análise multicritério a fim de levar em conta o aquecimento global, tema tão em voga ultimamente, no intuito de favorecer as alternativas de geração que não contribuam para o efeito estufa. Da mesma forma que o critério 'poluição atmosférica', o critério 'aquecimento global' pode ser avaliado de forma objetiva ou subjetiva.

\section{a) Avaliação Objetiva do critério Aquecimento Global}

As alternativas devem ser julgadas objetivamente quanto à emissão de gases de efeito estufa, cujos principais são: $\mathrm{CO}_{2}, \mathrm{CH}_{4}$ e $\mathrm{N}_{2} \mathrm{O}$.

A relação entre os gases de efeito estufa com o aquecimento global pode ser dada pelo índice $\mathrm{CO}_{2 \text { eq }}$ (dióxido de carbono equivalente). Este índice será utilizado para fins comparativos. A relação do metano com o dióxido de carbono é de 21 para 1. Já a relação entre o óxido nitroso é 310 para 1. Isso significa que a emissão de 1 tonelada de metano e 
de 1 tonelada de oxido nitroso equivalem a 21 e a 310 toneladas de dióxido de carbono, respectivamente.

$\mathrm{O}$ índice $\mathrm{CO}_{2 \mathrm{eq}}$ deverá ser o índice utilizado na avaliação objetiva explicada anteriormente, onde a alternativa com menor emissão equivale à nota dez e a de maior emissão à nota zero. Os índices que estiverem em posições intermediárias são avaliados de maneira proporcional.

\section{b) Avaliação Subjetiva do critério Aquecimento Global}

Caso não haja dados sobre a emissão de $\mathrm{CO}_{2 \mathrm{eq}}$, as alternativas serão avaliadas em relação às emissões médias do tipo de tecnologia. Na tabela a seguir, é apresentada uma referência para a avaliação subjetiva com relação à fonte de energia utilizada para geração de energia elétrica.

Tabela 4.7- Sugestão de avaliação do Aquecimento Global em função das fontes Classificação sugerida quanto ao Aquecimento Global em relação às fontes de energia

\begin{tabular}{|l|c|c|c|c|}
\hline \multicolumn{3}{|c|}{ Combustíveis fósseis } & \multicolumn{2}{c|}{ Fontes renováveis } \\
\hline Carvão & $\begin{array}{c}\text { Derivados do } \\
\text { petróleo }\end{array}$ & Gás Natural & Biomassa & Outras renováveis \\
\hline Muito alta & Alta & Média & Muito pequena & Muito pequena \\
\hline
\end{tabular}

\subsubsection{Outros impactos ambientais}

Este critério tem pó objetivo avaliar outros impactos ambientais causados pela geração de eletricidade diferentes da poluição atmosférica, no sentido de beneficiar as alternativas mais limpas ou com menor impacto ambiental, entre os quais os impactos ao solo e à água.

O critério em questão possui apenas avaliação do tipo subjetiva e para sua correta avaliação devem ser observados os seguintes aspectos, entre outros:

- Inundação de áreas, se houver;

- Rejeitos prejudiciais ao meio ambiente jogados na água e no solo;

- Ruído e poluição visual excessivos;

- O desmatamento provocado pelo uso de determinada tecnologia. 


\subsubsection{CRITÉRIOS TÉCNICOS}

\subsubsection{Disponibilidade e confiabilidade do serviço de energia elétrica}

A 'disponibilidade e confiabilidade do serviço de energia elétrica' é um item que considera o quão disponível e confiável é o fornecimento de energia elétrica aos habitantes da comunidade e se relaciona com o conforto dos habitantes e a regularidade do fornecimento de energia elétrica. Esta é uma avaliação é de natureza subjetiva e para uma correta avaliação devem ser observados os seguintes aspectos:

- Quanto mais confiável e robusto for o serviço de energia elétrica entregue aos usuários, maior é a nota neste item;

- É desejável que a energia disponível pelo sistema de geração tenha uma margem de segurança em relação à demanda estimada da comunidade analisada. Quanto maior for esta margem, melhor. Dessa forma, a margem de segurança, que é a energia oferecida ( $\mathrm{kWh} / \mathrm{ano})$ menos a energia demandada estimada, é um dado objetivo que deve ser considerado na avaliação deste critério;

- Os sistemas de geração que foram pouco testados e carecem de ajustes devem ser penalizados neste item, pois as incertezas quanto ao bom funcionamento destes sistemas é maior;

- Já os sistemas amplamente testados e com bons resultados devem receber uma boa avaliação neste critério.

\subsubsection{Operação e Manutenção}

A 'operação e a manutenção' são critérios relevantes para a escolha do tipo de geração em comunidades isoladas. Devido ao fato das comunidades isoladas estarem, evidentemente, em local de difícil acesso, é bastante desejável que o sistema de geração tenha operação e funcionamento confiáveis, que evitem imprevistos. Caso contrário, os moradores poderão ter prejuízos diversos na hipótese do sistema de geração deixar de funcionar regularmente e seja preciso esperar por reparação por pessoal especializado externo, o que pode demorar longos períodos devido à dificuldade de acesso ao local. Este critério é considerado subjetivo e visa avaliar as necessidades de operação e de manutenção, por pessoal especializado, na comunidade isolada. Devem ser observados os seguintes aspectos para a avaliação das alternativas de geração:

- Quanto menor a necessidade de manutenção destes sistemas, melhor; 
- Os custos anuais com operação e manutenção (O\&M), previstos na parte de análise financeira do projeto, são indicadores objetivos que devem ser considerados para balizar a avaliação.

\subsubsection{Necessidade de gerenciamento pelo lado da demanda}

Este critério, considerado subjetivo, tem como objetivo analisar a dependência do gerenciamento ou ajuste da demanda de energia à oferta do sistema de geração. Como exemplo de gerenciamento de demanda, pode-se citar o agendamento do funcionamento das cargas elétricas para não ultrapassar a potência nominal de geração. Quanto à avaliação neste critério, devem ser observados os seguintes aspectos:

- Restrições do sistema de geração quanto da potencia fornecida com relação ao horário de funcionamento. Por exemplo, a geração fotovoltaica que possui maior disponibilidade de potência durante o dia;

- Se potência demandada máxima for maior que a potência oferecida mínima pelo sistema de geração, pode haver necessidade de gerenciamento da demanda.

\subsubsection{Facilidade de aumento de oferta de energia}

A intenção de incluir este critério na avaliação das alternativas é favorecer as tecnologias que expandam, facilmente, a capacidade de oferta de energia, tipicamente a expansão em módulos. Diferentemente das cargas ligadas à rede convencional, o aumento das cargas alimentadas por um sistema de geração isolado pode ser limitado e condicionado ao aumento da capacidade de geração, que é geralmente mais difícil tecnicamente em sistemas isolados.

Este também é um critério subjetivo cuja avaliação deve contemplar os seguintes aspectos:

- Quanto mais fácil for aumentar a oferta de energia, melhor;

- Sistemas que não prevêem aumento da capacidade de geração para atender o aumento da demanda são considerados indesejáveis;

- O uso de módulos que podem ser acoplados para aumentar a geração é extremamente vantajoso, neste critério.

\subsection{ALTERNATIVAS DE PROJETOS DE GERAÇÃO}

Para concretizar a análise multicritério proposta neste trabalho é imprescindível que as alternativas de projetos de geração sejam apresentadas de forma a facilitar sua avaliação. 
Para fins práticos da análise multicritério, sugere-se que os projetos que estão sendo julgados pelo programa estejam incluídos em um documento contendo o resumo, os aspectos principais e a especificação básica. Já os projetos completos devem estar em anexo para conferência no caso de dúvidas. Estas sugestões têm a intenção de facilitar a avaliação dos projetos de geração pelo avaliador/especialista.

\subsection{FORMAS DE ELEGER OS PESOS DOS CRITÉRIOS}

Para eleger as preferências em relação aos critérios classificatórios e determinar os pesos de cada critério julgados justos na composição da nota final de cada projeto, são oferecidos dois métodos distintos que calculam a prioridade resultante de cada critério. Pode-se utilizar o método Swing ou o método 'Analityc Hierarchy Process'(AHP).

Oferecer as duas opções para eleição dos pesos tem a finalidade de facilitar e dar flexibilidade para que o avaliador o faça na forma mais conveniente, objetivando identificar as prioridades resultantes de forma coerente com as suas preferências.

\subsubsection{MÉTODO SWING}

Como já explicitado no capítulo anterior, o método SWING se inicia com a construção de dois cenários hipotéticos extremos, o $\mathrm{P}$ e o $\mathrm{M}$, onde o primeiro é composto pelo conjunto de todos os piores cenários de cada critério, já o ultimo é composto pelos melhores cenários em cada critério. Determinar as preferências consiste em pedir ao tomador de decisão para que observe cuidadosamente os potenciais ganhos em se mover do cenário $\mathrm{P}$ para o M, para, em seguida, decidir qual o primeiro critério a ser movido do cenário $\mathrm{P}$ para o M. Assumindo que esta primeira troca tem o valor de 100 unidades numa escala hipotética, o tomador de decisão é solicitado a atribuir outro valor hipotético $(<100)$ ao segundo critério movido para o cenário $\mathrm{M}$, em ordem de importância. A mesma forma acontece para o terceiro critério mais importante, e assim por diante até percorrer todos os critérios. Desta forma, são definidos os pesos de cada critério. A , retirada do aplicativo, ajuda a compreender o método Swing. Observe que prioridade resultante corresponde à coluna 'Peso' normalizada. 
Tabela 4.9 - Ilustração do método Swing

\begin{tabular}{|c|c|c|l|l|}
\hline \multirow{2}{*}{ Critério } & \multicolumn{2}{|c|}{ Cenário } & \multirow{2}{*}{} & Prioridade \\
\cline { 2 - 3 } & Pior & Melhor & Peso & Resultante \\
\hline R\$/kWh & & & & \\
\hline $\begin{array}{c}\text { Snergia entre o } \\
\text { combustivel e } \\
\text { atividades produtivas } \\
\text { locais }\end{array}$ & & & & \\
\hline $\begin{array}{c}\text { Operação manual do } \\
\text { sistema por } \\
\text { moradores locais }\end{array}$ & & & & \\
\hline
\end{tabular}

\subsubsection{MÉTODO ANALITIC HIERARCHY PROCESS (AHIP)}

O método AHP, criado por Saaty (1991), pode ser usado na quantificação das características qualitativas, permitindo a ponderação de todas as características e a priorização dos critérios. Segundo o autor, sua teoria "reflete o que parece ser um método natural de funcionamento da mente humana". Este método AHP fundamenta-se na comparação em pares entre diversos aspectos. Neste caso, são comparados, aos pares, os 11 critérios para avaliação de projetos de geração em comunidades isoladas. Nestas comparações, a medida de comparação consiste na prevalência de um critério em relação ao outro. Estas prevalências devem seguir a escala contida na tabela proposta por Saaty (figura a seguir). 


\begin{tabular}{|c|c|c|}
\hline \multicolumn{3}{|c|}{ Escala proposta por Saaty } \\
\hline $\begin{array}{l}\text { Intensidade de } \\
\text { importância }\end{array}$ & Definição & Explicação \\
\hline 1 & Mesma importância & $\begin{array}{l}\text { As duas atividades contribuem } \\
\text { igualmente para o objetivo }\end{array}$ \\
\hline 3 & $\begin{array}{l}\text { Importância pequena de uma } \\
\text { sobre a outra. }\end{array}$ & $\begin{array}{l}\text { A experiência e o julgamento } \\
\text { favorecem levemente uma } \\
\text { atividade em relação à outra. }\end{array}$ \\
\hline 5 & Importância grande ou essencial & $\begin{array}{l}\text { A experiência e o julgamento } \\
\text { favorecem fortemente uma } \\
\text { atividade em relação à outra. }\end{array}$ \\
\hline 7 & $\begin{array}{l}\text { Importância muito grande ou } \\
\text { demostrada. }\end{array}$ & $\begin{array}{l}\text { Uma atividade é muito fortemente } \\
\text { favorecida com relação à outra; a } \\
\text { sua dominação de importância é } \\
\text { demostrada na prática. }\end{array}$ \\
\hline 9 & Importância absoluta & $\begin{array}{l}\text { A evidência favorece uma } \\
\text { atividade em relação à outra com } \\
\text { o mais alto grau de certeza. }\end{array}$ \\
\hline $2,4,6,8$ & $\begin{array}{c}\text { Valores intermediários entre os } \\
\text { valores adjacentes }\end{array}$ & $\begin{array}{c}\text { Quando se procura uma condição } \\
\text { de compromisso entre dua } \\
\text { definições }\end{array}$ \\
\hline Racionais & Razões resultantes da escala & $\begin{array}{c}\text { Quando a importância do } \\
\text { componente da coluna é maior } \\
\text { que o da linha. }\end{array}$ \\
\hline
\end{tabular}

Figura 4.1- Escalas de comparação do método AHP Fonte: Saaty modificado

Outro elemento importante no método AHP, é a matriz de comparações, que contém os índices resultantes das comparações entre os critérios. A matriz de comparação utilizada no aplicativo desenvolvido é apresentada na figura a seguir. 


\begin{tabular}{|c|c|c|c|c|c|c|c|c|c|c|c|}
\hline & C1 & $\mathrm{C}_{2}$ & C3 & $C 4$ & C5 & $\propto$ & $\mathrm{Cl}$ & C8 & 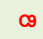 & C10 & C11 \\
\hline CI & 1 & 1 & 1 & 1 & 1 & 1 & 1 & 1 & 1 & 1 & 1 \\
\hline Q & 1 & 1 & 1 & 1 & 1 & 1 & 1 & 1 & 1 & 1 & 1 \\
\hline C3 & 1 & 1 & 1 & 1 & 1 & 1 & 1 & 1 & 1 & 1 & 1 \\
\hline CA & 1 & 1 & 1 & 1 & 1 & 1 & 1 & 1 & 1 & 1 & 1 \\
\hline C5 & 1 & 1 & 1 & 1 & 1 & 1 & 1 & 1 & 1 & 1 & 1 \\
\hline$\infty$ & 1 & 1 & 1 & 1 & 1 & 1 & 1 & 1 & 1 & 1 & 1 \\
\hline $\mathrm{C} 7$ & 1 & 1 & 1 & 1 & 1 & 1 & 1 & 1 & 1 & 1 & 1 \\
\hline 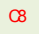 & 1 & 1 & 1 & 1 & 1 & 1 & 1 & 1 & 1 & 1 & 1 \\
\hline$\propto 9$ & 1 & 1 & 1 & 1 & 1 & 1 & 1 & 1 & 1 & 1 & 1 \\
\hline C10 & 1 & 1 & 1 & 1 & 1 & 1 & 1 & 1 & 1 & 1 & 1 \\
\hline C11 & 1 & 1 & 1 & 1 & 1 & 1 & 1 & 1 & 1 & 1 & 1 \\
\hline
\end{tabular}

Figura 4.3 - Matriz de comparações, método AHP. Fonte: Aplicativo desenvolvido

Observe que cada índice, $\mathrm{C} 1$ até $\mathrm{C} 11$, representam os critérios. O procedimento de preenchimento utilizado no aplicativo requer apenas que a matriz triangular superior seja preenchida, já que a diagonal é composta com elementos unitários e os elementos da matriz triangular inferior são dedutíveis pela equação (1) descrita mais adiante.

A prioridade resultante dos critérios, que é o produto final deste método, tem igual valor ao vetor T, mostrado mais adiante na equação (3).

A matriz de comparações é testada quanto a sua consistência, isto é, se os valores avaliados dos critérios são harmônicos entre si, se não há discrepâncias. Se houver discrepâncias, as prioridades resultantes deste processo de avaliação não são válidas, em tese. Dessa forma, deve ser revista avaliação dos critérios e modificados, caso seja necessário, até que a matriz fique consistente. A consistência é testada pelo índice Razão de Consistência (RC), equação (6).

OPERAÇÕES E EQUAÇÕES DO MÉTODO AHP

$$
a_{i j}=\frac{1}{a_{j i}}
$$

Onde $\mathbf{a}_{\mathbf{i j}}$ é o elemento da linha $\mathrm{i}$, coluna $\mathrm{j}$ da matriz de comparações.

O autovetor da matriz pode ser estimado pela seguinte fórmula: 


$$
W_{i}=\left(\prod_{j=1}^{n} \alpha_{i j}\right)^{1 / n}
$$

$\mathrm{O}$ autovetor deve ser normalizado para que o somatório de seus elementos seja igual à unidade. Basta, para isto, calcular a proporção de cada elemento em relação à soma.

$$
\mathrm{T}=\left\|\frac{\mathrm{W}_{1}}{\Sigma \mathrm{W}_{\mathrm{i}}}+\frac{\mathrm{W}_{\mathrm{z}}}{\mathrm{E} \mathrm{W}_{\mathrm{i}}}+\ldots+\frac{\mathrm{W}_{\mathrm{n}}}{\mathrm{E} \mathrm{W}_{\mathrm{i}}}\right\|
$$

Onde T é o autovetor normalizado e será utilizado para calcular as prioridades e calcular a consistência da matriz de comparações.

Para testar a consistência da resposta, o que indica se os dados estão logicamente relacionados, Saaty propõe o seguinte procedimento: estima-se inicialmente o autovalor $\left(\lambda_{\text {máx }}\right)$. A estimativa pode ser feita pela seguinte equação:

$$
\lambda_{\max }=T \cdot w
$$

Onde w é calculado pela soma das colunas da matriz de comparações. Calcula-se, então, o Índice de consistência (IC), através da seguinte expressão:

$$
I C=\frac{\left(\lambda_{\max }-n\right)}{(n-1)}
$$

A razão de consistência ( $\mathrm{RC}$ ) calculada através da equação (6). RC é a razão entre IC e um índice de consistência aleatória (CA). O índice CA, apresentado no quadro a seguir, é proveniente de uma amostra de 500 matrizes recíprocas positivas geradas aleatoriamente, de tamanho até 11 por 11 (Pamplona, 1999).

$$
R C=\frac{R C}{C A}
$$

Considera-se aceitável uma razão de consistência menor que 0,10. Para valores de RC maiores que 0,10 se recomenda uma revisão na matriz de comparações até que se obtenha $\mathrm{RC}$ menor ou igual a este valor (Pamplona, 1999).

Tabela 4.11 - Valores de CA em função da ordem da matriz Fonte: Pamplona, 1999.

\begin{tabular}{|c|c|c|c|c|c|c|c|c|c|c|c|}
\hline $\mathrm{n}$ & 1 & 2 & 3 & 4 & 5 & 6 & 7 & 8 & 9 & 10 & 11 \\
\hline $\mathrm{CA}$ & 0 & 0 & 0,58 & 0,9 & 1,12 & 1,24 & 1,32 & 1,41 & 1,45 & 1,49 & 1,51 \\
\hline
\end{tabular}




\subsection{ETAPAS DO AVALIADOR/ESPECIALISTA SEGUIDAS NO APLICATIVO MULTICRITÉRIO}

O avaliador das alternativas de projetos de geração deve ser especialista no assunto, com o devido conhecimento da problemática que envolve a geração de eletricidade em comunidades isoladas, assim como os aspectos técnicos tratados.

A avaliação das alternativas de geração foi elaborada para ser realizada em oito etapas ou passos. Estas etapas foram colocadas com o objetivo de facilitar a avaliação e permitir que ela seja feita de maneira coerente, a fim de revelar corretamente a preferência dos avaliadores. Estas etapas são as seguintes:

\section{1) Ler o objetivo do questionário}

Esta primeira etapa tem o intuito de instruir o avaliador quanto à finalidade do questionário e contextualizar-lo. O objetivo do questionário é apresentado na Tabela 4.13, tal como é feito no aplicativo.

Tabela 4.13 - Objetivo do questionário (avaliação)

\section{OBJETIVO DO QUESTIONÁRIO}

O propósito deste questionário é oferecer um método multicritérios para a tomada de decisão quanto a projetos de geração em comunidades isoladas. Os critérios foram especialmente selecionados e julgados importantes para a escolha das alternativas de geração em comunidades isoladas. Os critérios adotados englobam questões econômicas, ambientais, sociais e técnicas dos projetos. Este questionário deve ser respondido por especialistas ou tomadores de decisões que têm conhecimento técnico e sensibilidade sobre as questões referentes ao atendimento energético das comunidades isoladas no Brasil, assim como os impactos causados pela geração de energia elétrica (exemplo: impactos ambientais).

\section{2) Ler os Critérios Eliminatórios para os projetos de geração}

Os critérios de eliminação são apresentados no aplicativo em um link para um documento que contenha tais critérios. O documento padrão apresentado após selecionar o link, tem o mesmo conteúdo da seção 4.4. Aqui cabe observar que a instituição que utilizar esta 
metodologia e o aplicativo pode e deve criar ou modificar os critérios eliminatórios propostos, segundo a sua necessidade.

\section{3) Ler os Critérios Classificatórios para os projetos de geração}

Da mesma forma que ocorre para os critérios eliminatórios, é apresentado um link para o documento com as informações sobre os 11 critérios classificatórios. Este documento tem o mesmo conteúdo da seção 4.5 .

\section{4) Analisar os projetos ou alternativas de geração de energia elétrica disponíveis}

Nesta etapa devem ser analisados os projetos concorrentes para geração em comunidades isoladas que serão avaliados pelo aplicativo. O objetivo desta etapa é informar os projetos que serão avaliados ao avaliador sem a necessidade de um grande detalhamento. Deverão ser analisados alguns pontos essenciais, como: a tecnologia empregada, a compatibilidade do empreendimento com o local, os aspectos técnicos do funcionamento do sistema de geração, a existência dos dados objetivos requeridos para a análise (para os critérios objetivos), entre outros aspectos relevantes do projeto. É importante que aspectos que possam eliminar o projeto sejam levantados nesta fase.

Os projetos de geração concorrentes também devem ser apresentados ao avaliador. No aplicativo é previsto um link para um documento que tenha este conteúdo, no entanto, isto fica a cargo da instituição responsável pela análise.

\section{5) Inserir dados iniciais para a avaliação multicritério}

Este passo é importante para operacionalização do aplicativo para gerar os modelos de avaliação. É necessário inserir o número de projetos concorrentes e os tipos de avaliação (objetiva ou subjetiva) dos critérios 'poluição atmosférica' e 'aquecimento global'. Para estes dois critérios são permitidas ou avaliação objetiva ou subjetiva.

\section{6) Completar cada planilha de projeto com os dados referentes ao projeto}

Esta etapa consiste em inserir os dados objetivos de cada projeto, como $\mathrm{R} \$ / \mathrm{kWh}$, e as avaliações dos critérios subjetivos (notas parciais em função da menção atribuída) para cada projeto de geração. Cada projeto é avaliado em separado, em planilhas diferentes.

\section{7) Classificar os critérios classificatórios, elegendo pesos para cada critério}

Esta parte consiste em eleger pesos ou prioridades para todos os 11 critérios classificatórios propostos, que devem corresponder às preferências dos avaliadores, 
resultando em uma lista de classificação das prioridades elegidas, onde a soma das prioridades deve corresponder a $100 \%$. Para eleger os pesos dos critérios são disponibilizadas duas opções: método Swing de eleição dos pesos ou método AHP.

\section{8) Gerar a classificação final dos projetos e rever a avaliação, caso necessário}

Este é o ultimo passo da avaliação multicritério dos projetos e permite gerar, a partir dos dados de avaliação de cada projeto juntamente com as prioridades eleitas de cada critério, a classificação projetos de geração. Desta forma, os dados são consolidados e é gerada a nota final de cada projeto, além de outros dados. Estes dados estão dispostos em uma tabela flexível - 'tabela dinâmica' do Excel - capaz de mostrar os dados resultantes de diferentes formas. Sugere-se ao avaliador que faça uma revisão de suas escolhas caso o resultado the pareça desproporcional ou incoerente. Este é, portanto, um mecanismo de ajuste que ajuda o avaliador a expressar suas preferências em forma de valores.

\subsection{ETAPAS DA INSTITUIÇÃO RESPONSÁVEL POR REALIZAR A AVALIAÇÃO MULTICRITÉRIO}

A instituição, pública ou privada, interessada em financiar projetos de geração de energia elétrica em comunidades isoladas pode utilizar a metodologia multicritério aqui desenvolvida. Para tanto são sugeridos alguns passos que devem ser seguidos a fim de preparar a avaliação, direcionar a avaliação dos projetos concorrentes ao financiamento para a finalidade desejada e finalizar o processo de avaliação.

\subsubsection{DEFINIR OS CRITÉRIOS ELIMINATÓRIOS}

Primeiramente, a instituição deve definir os critérios eliminatórios para a avaliação multicritério. Para isso, deve definir a quantia máxima a ser investida no projeto de geração e escolher uma ou mais comunidades que poderão receber o benefício/investimento.

A escolha da(s) comunidade(s) isolada(s) alvo pode ser objeto de outro método de avaliação e de classificação. Embora este aspecto não seja tratado aqui, a avaliação baseada em critérios predeterminados fica como sugestão futura.

Dessa forma, a escolha da comunidade isolada a ser beneficiada fica a critério da instituição financiadora e deve estar baseada, logicamente, nos princípios perseguidos no emprego deste investimento social e conforme a conveniência da instituição investidora. Outros critérios, além dos sugeridos neste trabalho, também podem ser incluídos. Por exemplo, a proibição da concorrência de alternativas não renováveis, caso o intuito da 
instituição seja promover a geração a partir de fontes renováveis. A inclusão de novos critérios eliminatórios fica a cargo da instituição financiadora, com base nas suas necessidades.

\subsubsection{ORGANIZAR PROPOSTAS DE PROJETOS DE GERAÇÃO}

A instituição deve ser responsável por conseguir projetos de geração para concorrer ao financiamento. Ela pode fazer isto de diversas formas. Uma alternativa seria buscar estes projetos no mercado ou em universidades e submetê-los à avaliação multicritério. Outra forma é promover uma espécie de licitação com a divulgação adequada.

\subsubsection{SUBMETER OS QUESTIONÁRIOS AOS AVALIADORES /ESPECIALISTAS}

É importante que a avaliação multicritério proposta seja pautada em questionários respondidos por pessoas que conhecem a problemática do fornecimento de energia elétrica às comunidades isoladas e que possuam o conhecimento técnico mínimo de tais empreendimentos de geração. Cabe a instituição a nomeação dos especialistas que se submeterão a responder o questionário, com a especificação dos critérios e dos projetos de geração envolvidos.

\subsubsection{REUNIR OS QUESTIONÁRIOS RESPONDIDOS E LANÇAR A CLASSIFICAÇÃO RESULTANTE}

A partir dos questionários respondidos, a instituição tem em mãos as ferramentas necessárias para lançar uma classificação final das propostas de geração, com as suas respectivas notas.

Observe que apesar de ser considerado muito importante que o número de questionários respondidos por especialistas não seja muito pequeno, é possível que com apenas um questionário respondido a avaliação multicritério seja completa. Entretanto, uma avaliação multicritério respondida com apenas um ou poucos especialistas pode apresentar problemas. Um problema pode ser que o resultado da avaliação não seja produto da junção entre as diferentes correntes de pensamento dos especialistas sobre o assunto. Por exemplo, existem especialistas mais preocupados com as áreas ambientais e sociais; já outros tendem a valorizar muito mais a questão econômica do projeto. A avaliação por um pequeno grupo de especialistas, ou mesmo apenas um, pode ser tendenciosa e ter resultados pouco confiáveis. 
Existem mais de uma forma de agrupar os resultados dos questionários. No entanto, aqui é sugerida uma forma de reunião dos dados dos questionários para gerar a classificação final. FORMA SUGERIDA DE AGRUPAMENTO DE DADOS

Com os questionários todos respondidos, ter-se-ão os pesos dos critérios, as menções dos critérios subjetivos e os dados objetivos coletados dos projetos, com relação aos critérios objetivos.

A sugestão proposta para agrupamento dos dados para permitir o resultado final, pode ser dividida em quatro simples etapas:

1) Os pesos dos critérios devem ser uniformizados utilizando a média de todos os pesos coletados;

2) A partir do conjunto de menções julgadas em cada critério subjetivo, com suas respectivas notas de zero a 10, deve ser obtida a média de cada critério avaliado;

3) Os dados objetivos, como o $\mathrm{R} \$ \mathrm{kWh}$, devem ser confrontados. Caso haja discordância entre eles, os dados devem ser analisados. Em seguida deve-se fixar o dado julgado correto, eliminando os diferentes.

4) A nota final de cada projeto será dada pela multiplicação da nota média (nos critérios subjetivos) ou da nota relativa obtida (nos critérios objetivos), pela média dos pesos de cada critério (obtida anteriormente).

A partir das quatro etapas acima, a classificação final dos projetos pode ser divulgada em função da nota final obtida por todos os critérios.

\subsection{CONSIDERAÇÕES FINAIS}

A metodologia apresentada neste capítulo é a base do aplicativo desenvolvido para análise multicritério. Este capítulo procurou descrever os aspectos importantes da metodologia proposta para analisar os projetos de geração de eletricidade para comunidades isoladas.

Como visto na seção 4.3, a metodologia é estruturada em duas categorias de critérios - os eliminatórios e os classificatórios, estes últimos responsáveis pela avaliação multicritério. Foram apresentados 11 critérios classificatórios na tentativa de abranger os aspectos importantes na escolha da alternativa de geração que englobam desde aspectos econômicos, sociais, ambientais, até técnicos. Cada critério foi detalhado quanto ao seu propósito e os aspectos que devem ser levados em consideração na avaliação. Especificamente em dois critérios, criou-se a possibilidade de serem objetivos ou 
subjetivos, com preferência ao tipo objetivo quando envolver dados objetivos. Quanto aos critérios subjetivos, para determinados critérios foram apresentadas tabelas de referência para a avaliação, no sentido de balizar as avaliações.

Os dois diferentes métodos de eleição de pesos aos critérios - Swing e AHP - foram descritos, assim como suas formulações matemáticas pertinentes (método AHP). Pode-se concluir que a existência de duas opções para eleição de pesos dos critérios tende a enriquecer e dar maior credibilidade à análise multicritério.

As etapas que o avaliador deve seguir para realizar a avaliação multicritério foram apresentadas na seção 4.6, com os mesmos passos previstos no aplicativo. Sua estrutura permite que sejam revistas etapas anteriores para que evitar erros na avaliação.

Por último foram apresentados procedimentos sugeridos à instituição para viabilizar a aplicação de questionários aos especialistas e permitir obter a análise final, resultado do agrupamento dos questionários submetidos. 


\section{APLICATIVO MULTICRITÉRIO}

\subsection{CONSIDERAÇÕES INICIAIS}

Este capítulo aborda os aspectos construtivos do aplicativo elaborado em Excel ${ }^{\circledR} 2007$ e a sua forma de utilização. É apresentado, também, um exemplo de utilização.

\section{ESTRUTURA DO CAPÍTULO}

Esse capítulo se inicia com uma apresentação do aplicativo quanto aos seus objetivos e em seguida, aborda os aspectos construtivos do programa. Já a seção 5.2.2 explica passo-apasso sua utilização, onde são mostradas imagens de partes do programa. Também detalha a utilização do aplicativo desde os primeiros passos, passando pelas formas de eleição dos pesos, até os resultados finais gerados pelo aplicativo.

$\mathrm{Na}$ seção seguinte, 5.3, é apresentado um exemplo com oito alternativas de geração de eletricidade à comunidades isoladas que foram submetidas à análise pelo aplicativo e que contém uma análise de sensibilidade dos resultados à variação das prioridades vinculadas aos critérios. Dentro desta seção, no item ou sub-seção 5.3.1 são apresentadas alternativas de geração de eletricidade, a partir do exemplo, e um resumo do resultado obtido da avaliação quanto aos critérios adotados. $\mathrm{Na}$ sub-seção 5.3.2, são mostrados os resultados gerados em razão das prioridades eleitas a partir dos métodos Swing e AHP. Já na subseção 5.3.3, são demonstrados os resultados finais obtidos e as classificações das alternativas identificadas. Por último, é apresentado o resultado do teste da sensibilidade dos resultados obtidos após submissão a um avaliador que dá maior importância aos aspectos ambiental e social.

\subsection{APLICATIVO}

\subsubsection{INTRODUÇÃO E OBJETIVO DO APLICATIVO}

O aplicativo foi elaborado para servir de interface e plataforma para a metodologia multicritério descrita no capítulo 4, permitindo que a avaliação fosse elaborada de maneira sistemática e eficiente, onde os resultados das avaliações pudessem ser disponibilizados de maneira interativa e favorecessem que as preferências dos avaliadores sejam, de fato, convertidas nos valores e números fornecidos. 
O aplicativo roda no Excel ${ }^{\circledR} 2007$ ou Excel ${ }^{\circledR}$ versão 2003, e não é exigida instalação, pois todo o seu conteúdo está dentro de arquivos com extensão xls ou xlsm.

\subsubsection{ASPECTOS CONSTRUTIVOS DO APLICATIVO}

O aplicativo foi elaborado na plataforma Excel $^{\circledR} 2007$ utilizando as interfaces gráficas inerentes ao programa e à programação Visual Basic for Aplications (VBA). VBA é uma implementação da Microsoft Visual Basic, que utiliza uma programação voltada para eventos associada a um ambiente de programação que podem ser construídas em quase todos os aplicativos Microsoft Office ${ }^{\circledR}$.

Este aplicativo constitui-se: de cinco planilhas expostas (não-ocultas), que dão suporte e servem de interface gráfica; de um formulário para inserção de dados iniciais; e de um módulo de códigos com mais de 50 rotinas e funções. Outras planilhas estão disponíveis de forma oculta, como: a planilha 'base de dados' e os padrões de planilha-projeto.

A partir das planilhas expostas, principalmente da planilha 'Principal', o usuário é orientado sobre os passos necessários para realizar a avaliação multicritério. Para atender às necessidades surgidas no decorrer da avaliação, o programa permite criar ou excluir planilha automaticamente, de modo a garantir que os passos da avaliação sejam seguidos, além de dar flexibilidade ao processo uma vez que planilhas para coleta de dados são criadas em função do número de projetos inseridos e dos tipos de critérios (objetivo ou subjetivo).

Os cálculos necessários no aplicativo são realizados na própria planilha, utilizando as ferramentas e as facilidades disponíveis no ambiente Excel $^{\circledR}$.

Todos os dados coletados são inseridos em uma planilha única, denominada 'base de dados', por meio da qual são gerados os resultados finais. Esta mesma planilha é usada como o resumo das avaliações realizadas por cada avaliador, na hipótese do questionário (aplicativo) ser respondido por mais de um avaliador/especialista. Também é usada para agregar consolidar os dados e gerar um resultado consolidado de todas as avaliações. .

\subsubsection{UTILIZANDO O APLICATIVO}

O passo inicial, obviamente, é abrir o arquivo no programa Excel ${ }^{\circledR}$. Em seguida, aparece planilha 'Principal' na tela que contém todos os passos necessários para execução da 
análise e os botões de operacionalização do programa. Esta planilha é mostrada na Figura 5.1 .

O $1^{\circ}$ passo é constituído pela leitura do objetivo do questionário, como indicado na Figura 5.1, a fim de situar o avaliador e contextualizá-lo quanto ao propósito a ser seguido.

$\mathrm{O} 2^{\circ}$ e o $3^{\circ}$ passos permitem que o avaliador conheça os critérios eliminatórios e classificatórios contidos no programa. Também são fornecidas orientações nos documentos disponibilizados nos links e devem ser sempre usados em caso de dúvida.

Já o $4^{\circ}$ passo permite a análise dos projetos de geração concorrentes entre si. Essa etapa depende das providências do ator responsável pela análise multicritério, ou seja, pode ser disponibilizado um ou mais documentos com as informações e especificações dos projetos concorrentes.

No $5^{\circ}$ passo o avaliador deve clicar no botão $<$ Inserir $>$ para informar o número do projeto e definir os tipos de critérios - objetivos ou subjetivos - para os aspectos 'Poluição Atmosférica' e 'Aquecimento global', de forma a organizar a lógica do aplicativo. 


\section{Passos a se rem se guidos pelos avaliadores}

\section{Passo: $\quad$ Ler o Objetivo do Questionário}

Objetivo do Questionário

O propósito dest e questionário é oferecer um méto do mu ltic ritérios para a tomada de decisão quant o a projetos de geração em comunid ades isol adas. Os critérios fo ram especialment e selecion ados e julgados im portantes para a escolha das alternativas de geração em com uni dades iso ladas. Os critérios adotados englobam questões econômic as, ambient ais, sociaise técnic as dos projetos. Este questionário deve ser respondido por especialist as ou tom adores de decisões que têm conhecim ento técnico e sensibilidade so bre as qu estões referentes ao atendimento energético das comu nidades isoladas no Brasil, assim com o o simpactos causados pela geração de energia elétrica (ex em plo: im pactos am bientais).

\section{$2{ }^{\circ}$ Passo: $\quad$ Ler os Critérios Eliminatórios para os projetos de geração}

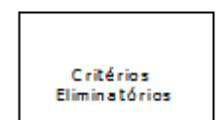

$3^{\circ}$ Passo: Ler os Critérios Classificatórios para os projetos de geração

\section{$4^{\circ}$ Passo: Analisar os projetos ou altern ativas de geração de energia elétrica dispon íveis}

Nest a etapa devem ser analisados os projeto s concorrent es para geração em comunidadesi soladas que serão avaliados por este program a O objetivo nest a etap a é que o avaliador conheça os projetos que serão avaliados, sem a necessidade de um grande detalhamento. Deverão ser anal isados alguns pont os essenciais com o: a tecnologia em pregada, a com patibilidade do empreend im ent o com o local, aspectos técn icos do funcionam ento do sistema de geração, a existência dos dados o bjetivos requ eridos para a anál ise (para os critériosobjetivos), entre outros aspectos relevantes do projeto. É importante que aspectos que possam elim inar o projeto sejam levant ados nesta fase.

UNKS PARA O DOCUM ENTO QUE CONTEM OSPROJETOS DISP ONIVEIS

5 ${ }^{\circ}$ Passo: In serir dados in iciais para a Avaliação multicritério, clican do no botão abaixo

Abrir formulário

6 ${ }^{\circ}$ Passo: Completar cada planilha de projeto com os dados referentes aos projetos

Ir para os projetos

$7^{\circ}$ Passo: Classificar os critérios classificatórios, elegen do o peso de cada critério, na planilha 'Classificação dos Critérios'

Ir para Cassifi caçẫo dos critérios

$8^{\circ}$ Passo: Gerar a classificação final dos projetose rever a avaliação se necessário

Mostrar Resultados

Figura 5.1- Planilha principal do aplicativo 
O $6^{\circ}$ passo consiste em avaliar cada projeto quanto aos critérios, sendo que no caso dos critérios objetivos apenas se exige a inserção de dados e no dos critérios subjetivos é preciso atribuir notas e as respectivas justificativas. Na Figura 5.3 é apresentada uma ilustração da imagem da planilha dos projetos-padrão.

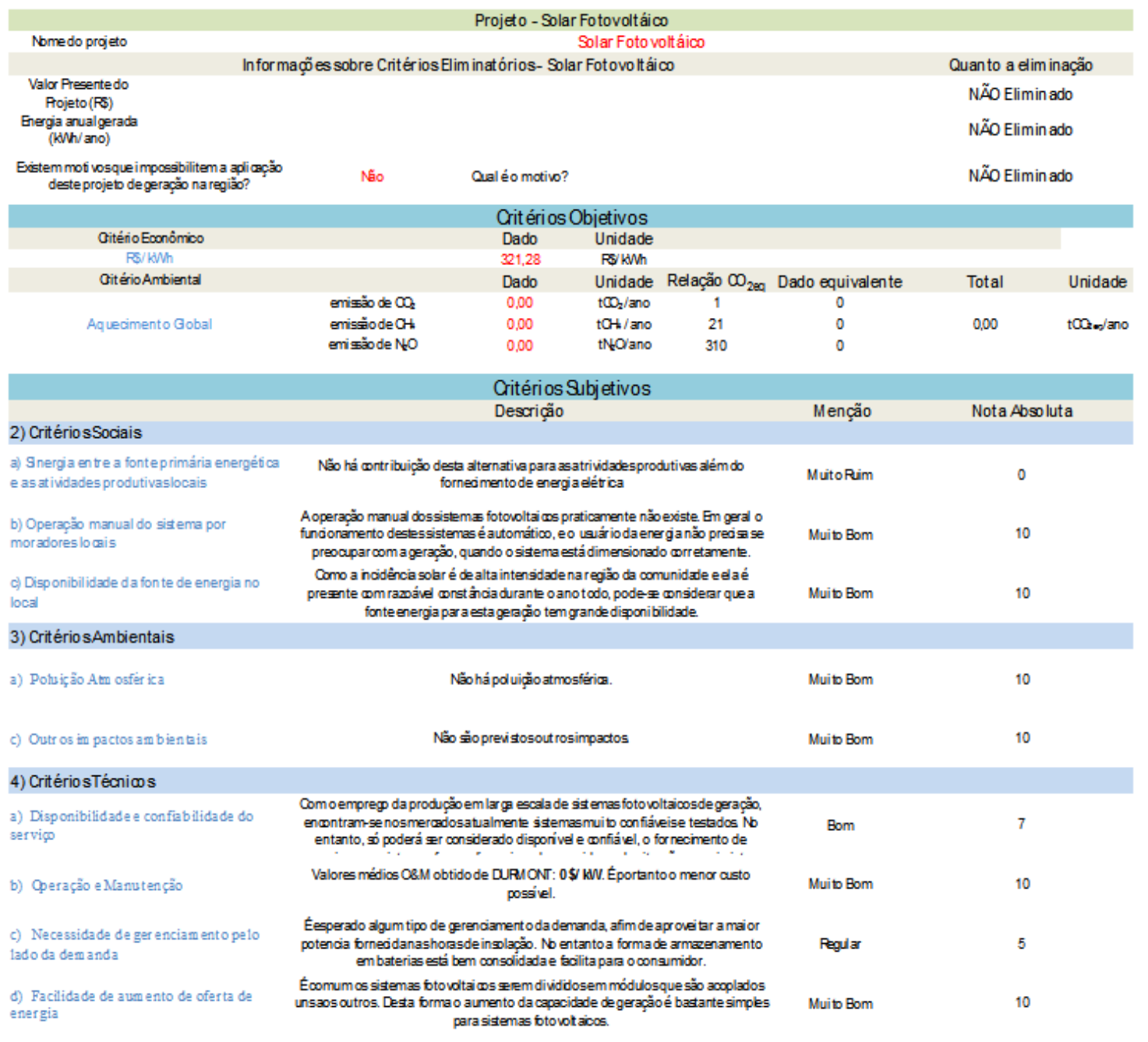

Figura 5.3 - Planilha dos projetos preenchida

No $7^{\circ}$ passo devem ser atribuídos os pesos subjetivos para cada critério conforme as preferências do avaliador. Para isso, é necessário selecionar botão <nome do botão>, disposto logo abaixo da instrução do sétimo passo, de forma a exibir a planilha 'Classificação Critérios', conforme ilustrado na Figura 5.5. 


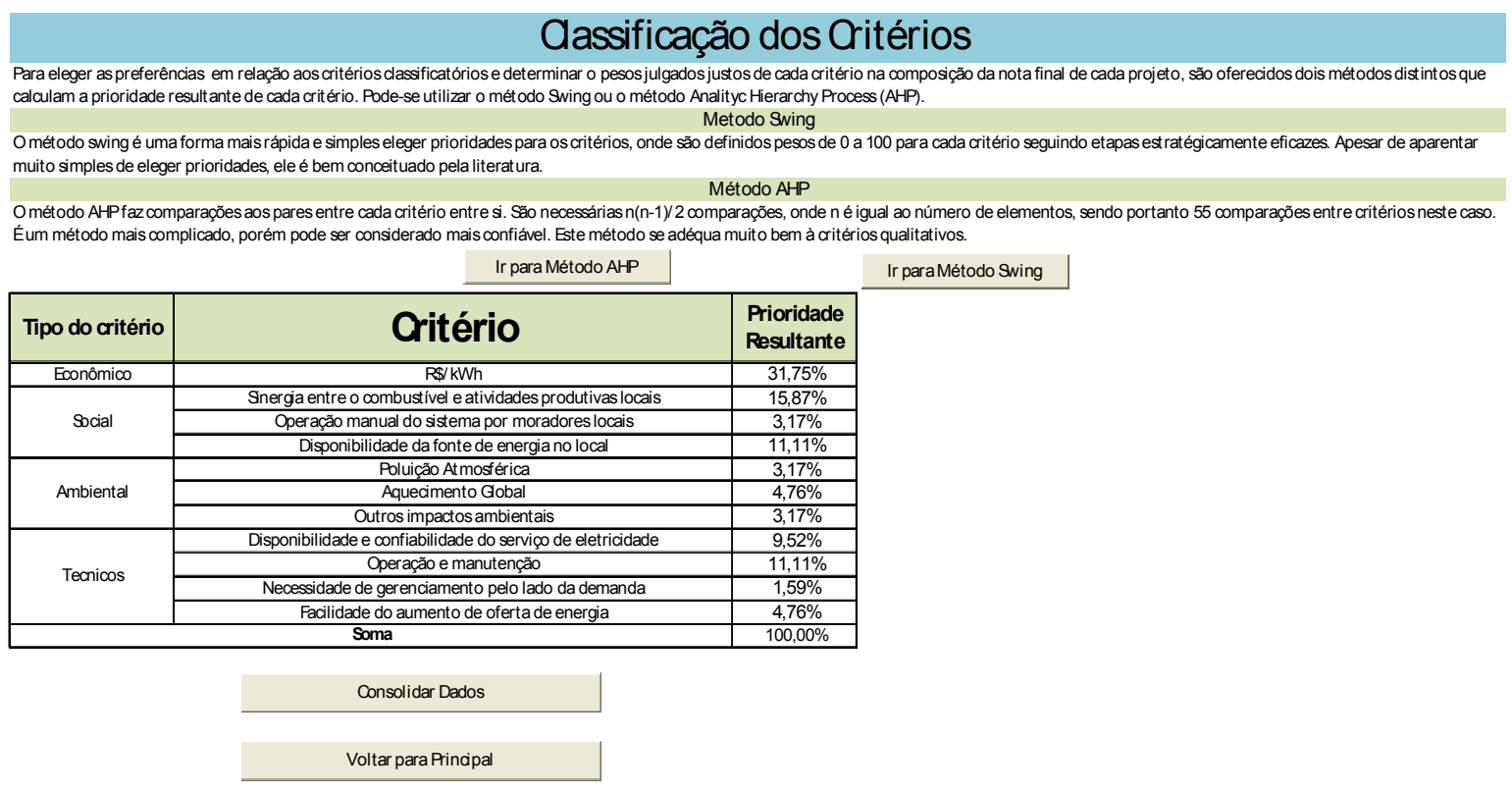

Figura 5.5- Planilha Classificação dos Critérios, elegendo pesos para os critérios

Para permitir a eleição dos pesos dos critérios são oferecidas duas opções: método Swing e método AHP. Uma explicação destes dois métodos está disponível na planilha. O usuário deverá escolher uma das duas opções. Para selecioná-lo, basta clicar no respectivo botão.

\section{MÉTODO SWING}

Ao escolher o método Swing, será exibida uma planilha com instruções para o preenchimento dos pesos, em forma de passos a serem seguidos. Os cenários melhor e pior são preenchidos automaticamente para os critérios objetivos. Já os cenários referentes aos critérios subjetivos deverão ser preenchidos com as alternativas de geração correspondentes para possibilitar o prosseguimento dos passos subsequentes previstos no método Swing, como explicado na instrução.

Após o preenchimento da coluna 'Pesos', o usuário visualizará a classificação resultante clicando no botão <nome do botão $>$ disponível na parte inferior da tabela. Depois de concluída a definição dos pesos, o usuário deverá voltar para planilha 'Classificação Critérios'. Essa operação gera, automaticamente, a planilha 'Classificação dos Critérios' com as prioridades definidas para os critérios de acordo com o método (Figura 5.7). 
M ét odo Swing com critérios objetivos e subjetivos

$1^{\circ}$ Passa; Preencrer nocampo Cerráriq os piorese melhores projedoscam relaçao aoscritériosavaliadosrelativos apenasaoscritérios Suljetivos $2 \circ$ Passo Observar o potencial garhoentre o Pior e o Melhor Cenánio

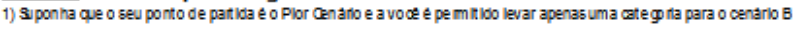

2) S.jponna que agora aqu voce pose mover tambem um se gunso crner lo pa a o Nelnor chana.

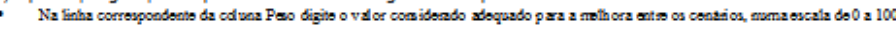

3) Cont hue ete prossolmento para 05 criterlos restantes um aposo outro

$3^{\circ}$ Passo: Observe aspricridades resitantescalculadas pelo Exoel

$4^{\circ}$ Passo: Paree revise suas preferencias

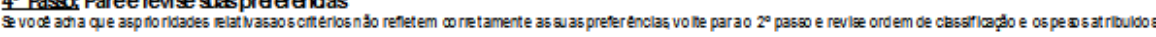

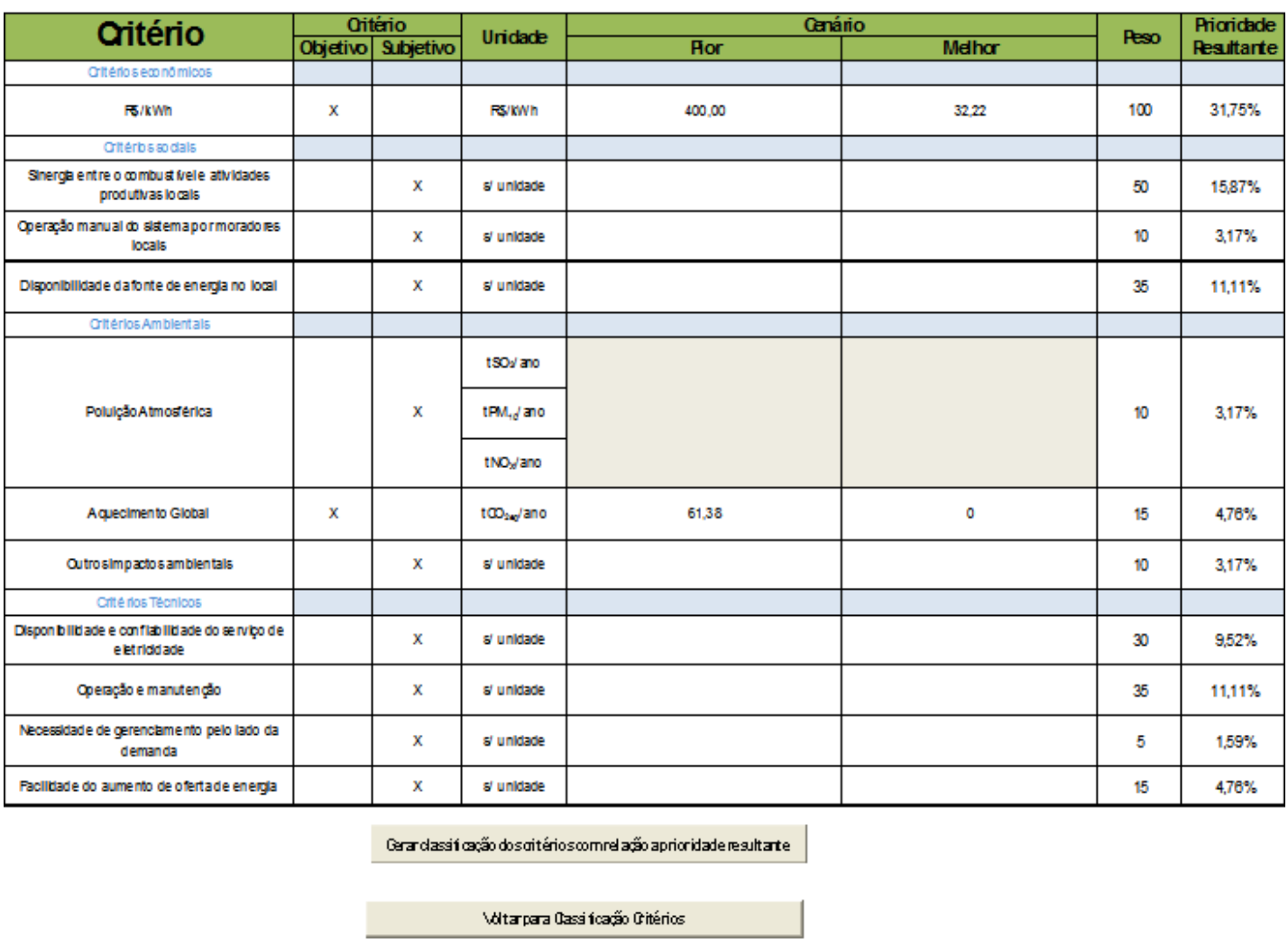

Figura 5.7 - Planilha com o método Swing

\section{METODO AHP}

Caso seja escolhido o método AHP, será mostrada uma planilha (Figura 5.9) com instruções de preenchimento da matriz de comparação entre os critérios, que deve ser preenchida para que sejam eleitas as prioridades resultantes de cada critério. Para facilitar o preenchimento e evitar que o avaliador tenha que recorrer freqüentemente à legenda dos critérios, foi desenvolvido um mecanismo que após a seleção da a célula dentro da matriz, gera uma mensagem informando quais critérios estão sendo comparados entre si (Figura $5.11)$. 


\begin{abstract}
Instruções de como utilizar o método Analityc Hierardhy Process (AHP)
1) Ométodo AHP

O mét odo AHP fundam enta-se na comparação aos em paresentre diversos așectos. Neș ecaso, serão comparados, aos pares, os critériospara avaliação de projet os de geração em comunid ades isoladas. Os critér ios que serão avaliados são os critérios dassificat órios pr opo so sn este documento, ajjas as siglas C1 até C11 correspondem respectivament e aos $\sigma$ itérios que eșão mostrados na legenda, localizado ab aixo da M atrizde Comparaçöes 0 preenchimento da parte triangular superior (em laranja) da M atrizde Co mparaçôesé necessário para que sejam inferidasas prioridadesde cada đitério.
\end{abstract}

\title{
2) Peenchimento da Matrizde Comparações
}

Para o cor reto preenchimento da matriz de comparação é necessário identi ficar cada critério (siglas C1 a C11) epreencher o valor de preferência de um critério sobreoutro, de aco rdo com a escal a pro posta por Saaty, m ostr ada abaixo da $M$ at riz de Comparação. 0 preenchimento deveo $\infty$ rrer da seguinte forma: o critério que $\infty$ r esponde à linha é comparad o ao critério na coluna. Na celula, lê-se: 0 critério da linh a tem preferenciade valor X sobre o critério da coluna. Devem ser prenchidasapenas a parte triangular su perior da matriz de œ mparaçōes (em laranja) Exemplo: Se o criério C1 tiver importância absolut a em relação ao critério C2, mar ca-se o númer o 9 na linha 1 coluna 2, de acordo com a escala proposta por Saaty.

\section{3) Consist ência da Matriz de Comparações}

Amatr iz de œ mp araçôesé teșada quanto a sua consistência, isto é, se osval oresavaliados doscritérios são har mô nicosentre si, se não há discepâncias Se houver discrep âncias as prioridades result antes deste processo de avaliação não são válidaș em tese. Dessa forma, deve ser revișa avaliação do critériose modificadascaso necessár io, até que a matriz seja œ nsistente. A consistênda é teșada por um índice (Raz̃o de Consistêndia)

Figura 5.9- Instruções - planilha 'método AHP'

\section{Matriz de Comparações dos critérios}

\begin{tabular}{|c|c|c|c|c|c|c|c|c|c|c|c|}
\hline & C1 & C2 & C3 & C4 & C5 & $C 6$ & C7 & C8 & $\boldsymbol{c}$ & $\mathrm{C10}$ & C11 \\
\hline $\mathrm{Cl}$ & 1 & 6 & 9 & 8 & 8 & 7 & 8 & 6 & 7 & 9 & 6 \\
\hline C2 & $1 / 6$ & 1 & 5 & 3 & 3 & 4 & 5 & 4 & 4 & 7 & 3 \\
\hline С & $1 / 9$ & $1 / 5$ & 1 & $1 / 5$ & 1 & $1 / 3$ & $1 / 2$ & $1 / 4$ & $1 / 5$ & 1 & $1 / 4$ \\
\hline C4 & $1 / 8$ & $1 / 3$ & 5 & 1 & 4 & 3 & 5 & 1 & 1 & 5 & 1 \\
\hline C5 & $1 / 8$ & $1 / 3$ & 1 & $1 / 4$ & 1 & 1 & 1 & $1 / 4$ & $1 / 5$ & 2 & $1 / 3$ \\
\hline 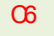 & $1 / 7$ & $1 / 4$ & 3 & $1 / 3$ & 1 & 1 & 2 & $1 / 2$ & $1 / 5$ & 3 & $1 / 2$ \\
\hline $\mathrm{C7}$ & $1 / 8$ & $1 / 5$ & 2 & $1 / 5$ & 1 & $1 / 2$ & 1 & $1 / 4$ & $1 / 4$ & 1 & $1 / 4$ \\
\hline$\subset$ & $1 / 6$ & $1 / 4$ & 4 & 1 & 4 & 2 & 4 & 1 & 1 & 3 & 1 \\
\hline c9 & $1 / 7$ & $1 / 4$ & 5 & 1 & 5 & 5 & 4 & 1 & 1 & 5 & 1 \\
\hline C10 & $1 / 9$ & $1 / 7$ & 1 & $1 / 5$ & $1 / 3$ & $1 / 3$ & 1 & $1 / 3$ & $1 / 5$ & 1 & $1 / 4$ \\
\hline Cl1 & $1 / 6$ & $1 / 3$ & 4 & 1 & 2 & 2 & 4 & 1 & 1 & 4 & 1 \\
\hline
\end{tabular}

Figura 5.11 - Matriz de comparações - planilha 'método AHP' 

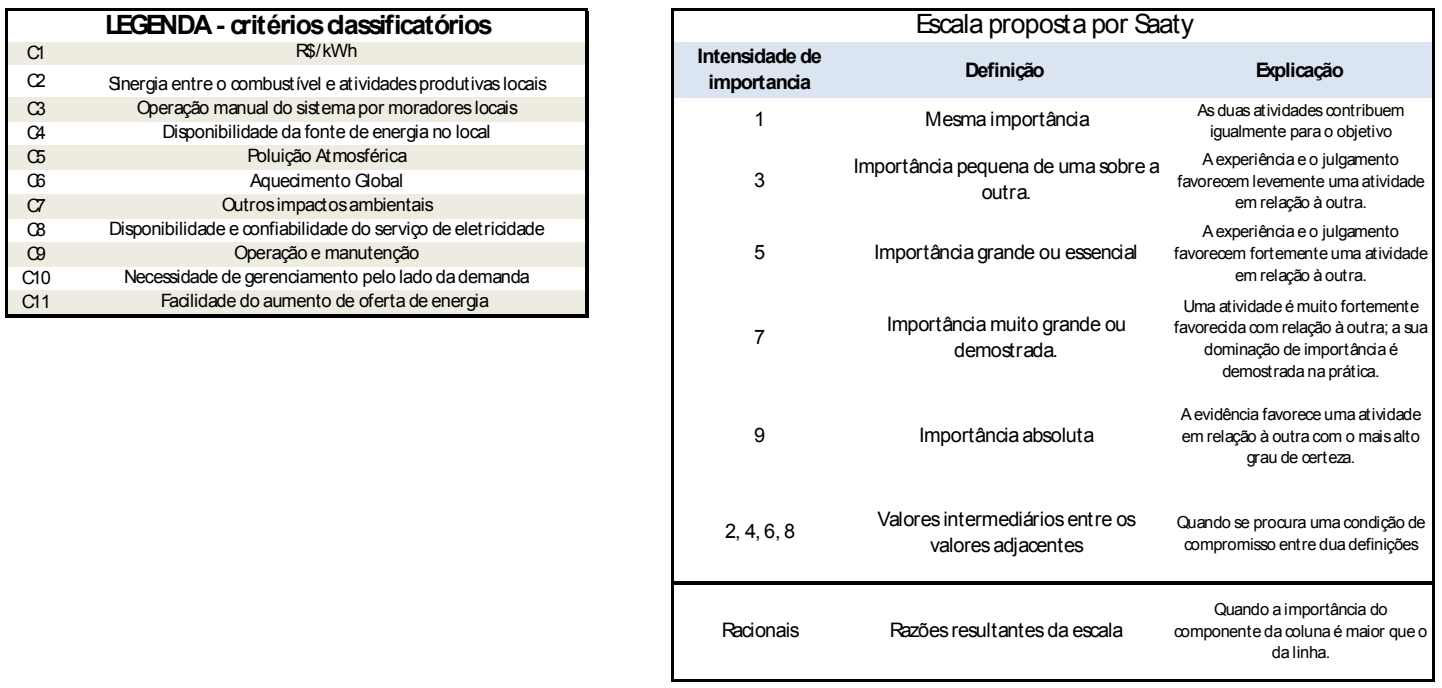

Figura 5.13- Legenda e tabela com a Escala das dos valores de comparação - planilha 'método AHP' O usuário deve levar em consideração a escala proposta por Saaty (Figura 5.13), criador do método AHP, pois é nela que o preenchimento da matriz de comparações deve estar baseado.

Por último, o programa gera automaticamente uma análise da consistência da matriz de comparações, testando a coerência entre as mesmas ${ }^{11}$. Caso a matriz não esteja consistente, o programa exibe uma mensagem com alertando para o fato e orientando para sejam revistas as comparações. Após a conclusão destas etapas, o usuário deve retornar à planilha 'Classificação Critérios'. Essa operação gera, automaticamente, uma planilha-padrão com as prioridades resultantes do método AHP.

\section{PARTE FINAL}

Ao retornar a planilha 'Classificação Critérios', independente do método selecionado pelo usuário, deverá ser selecionado o botão 'Consolidar Dados' para que seja concluída a avaliação. Esta etapa é pré-requisito para que classificações finais das alternativas possam ser geradas. Em seguida, o usuário deverá voltar à planilha 'Principal' para acessar o último passo (oitavo passo).

${ }^{11}$ A base teórica para os cálculos da coerência da matriz e as prioridades resultantes do processo está na seção 4.6.2 
O $8^{\circ}$ passo, na planilha 'Principal', consiste em mostrar os resultados da avaliação multicritério por meio da seleção do botão <nome do botão $>$. Por meio desta última ação, será gerada uma tabela flexível, denominada 'tabela dinâmica', que exibe o resultado final em diversas formas, os quais podem ser exibidos por meio da seleção dos parâmetros da tabela dinâmica. A mostrada a seguir é uma das formas de visualização do resultado. 
Tabela 5.1 - Exemplo de resultado mostrado pelo aplicativo.

\begin{tabular}{lcccc} 
& & Nota & Prioridade Resultante dos & \\
& Geração Eólica & Parcial & critérios & NOTA \\
\hline $\mathrm{R} \$ / \mathrm{kWh}$ & & 9,515743 & 0,368771577 & 3,5091
\end{tabular}

a) Snergia entre a fonte primária energética e as atividades produtivas locais

b) Operação manual do sistema por moradores locais

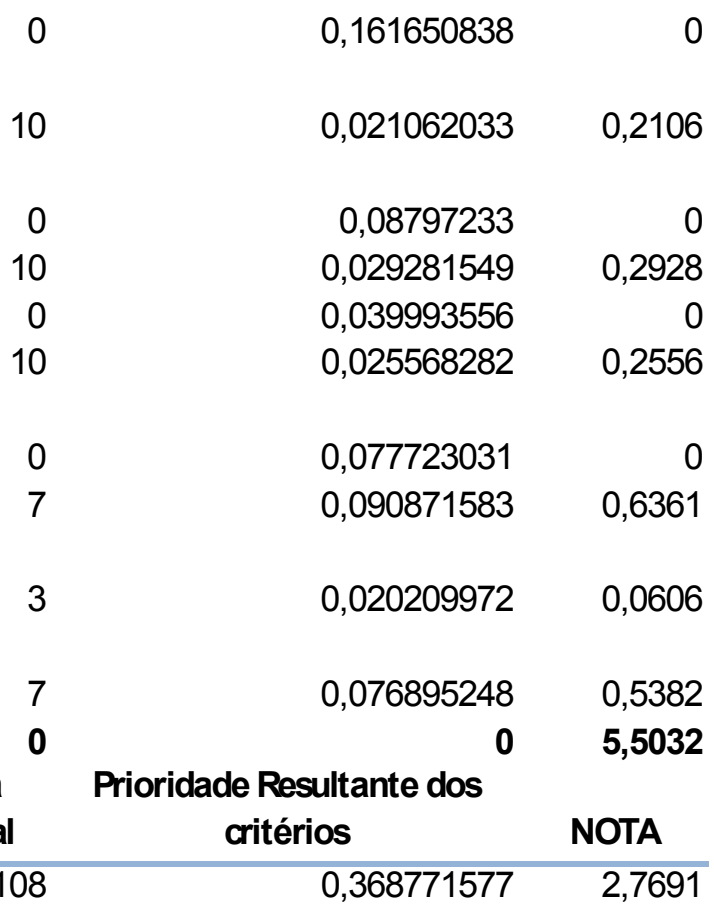

c) Disponibilidade da fonte de energia no local

a) Poluição Atmosférica

0,029281549 2928

b) Aquecimento Gobal

c) Outros impactos ambientais

a) Disponibilidade e confiabilidade do serviço

b) Operação e Manutenção

\section{0}

c) Necessidade de gerenciamento pelo lado da demanda

2,7691

d) Facilidade de aumento de oferta de energia

Nota final

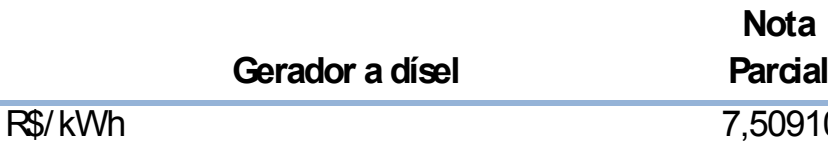

a) Snergia entre a fonte primária energética e as atividades produtivas locais

0,161650838

0

b) Operação manual do sistema por

moradores locais

$\begin{array}{rrr}7 & 0,021062033 & 0,1474 \\ 0 & 0,08797233 & 0 \\ 3 & 0,029281549 & 0,0878 \\ 0 & 0,039993556 & 0 \\ 10 & 0,025568282 & 0,2556\end{array}$

c) Disponibilidade da fonte de energia no local

a) Poluição Atmosférica

10

0,077723031

0,388615

a) Disponibilidade e confiabilidade do serviço

5

0,090871583

c) Necessidade de gerenciamento pelo lado da demanda 10

0,020209972

0,202

d) Facilidade de aumento de oferta de energia

0,076895248

0,7689

Nota final

0

$0 \quad 4,6197$

A partir da visualização dos resultados na 'tabela dinâmica', o usuário poderá encerrar a avaliação, caso deseje representar suas preferências, ou poderá revisar as avaliações posteriormente para gerar novos resultados. 
Desta forma, encerra-se a avaliação das alternativas de geração. Os resultados da avaliação sobre as alternativas deverão ser consolidados ao final pelo responsável pela avaliação multicritério, gerando ao menos uma classificação final.

\subsection{EXEMPLO DE APLICAÇÃO: AVALIAÇÃO DE OITO ALTERNATIVAS HIPOTÉTICAS DE GERAÇÃO}

São analisados, nesta seção, oito diferentes alternativas de geração para verificar o funcionamento e validar o aplicativo desenvolvido, assim como identificar aspectos positivos e negativos do mesmo.

\subsubsection{AS OITO ALTERNATIVAS DE GERAÇÃO}

As oito alternativas de geração propostas são descritas aqui de forma genérica e sem detalhamento, pois este não faz parte do escopo deste trabalho. As informações sobre estas alternativas foram obtidas principalmente das seguintes referências: Veronese, da onde foram tirados os custos econômicos diretos da geração (US\$/MWh.ano) e custo de O\&M típicos das tecnologias; e de diversas fontes na internet sobre as tecnologias e seus impactos ambientais e sociais possíveis.

Estes oito exemplos são avaliados no programa pelo autor deste trabalho, que não é um especialista no assunto, mas tentou-se buscar coerência nas avaliações das alternativas, com base no conhecimento prévio das alternativas e nas referencias já citadas.

As alternativas concorrentes utilizadas no aplicativo são:

1) Solar Heliotérmica;

2) Solar Fotovoltaica;

3) SHGH - Sistema Híbrido de Geração Distribuída ${ }^{12}$;

12 O SHGD é composto por painéis fotovoltaicos, células a combustível e baterias. O sistema fotovoltaico alimenta o sistema de geração como um todo fornecendo energia para carga os dois sistemas de armazenamentos de energia, baterias e tanques de hidrogênio produzidos por eletrólise. Este é o projeto do Professor Mauro Moura Severino, UnB. 
4) Eólica;

5) Turbinas Hidrocinéticas;

6) Biomassa - Cana;

7) Biomassa - Gás do Lixo;

8) Gerador a dísel.

Estas alternativas foram avaliadas quanto aos onze critérios (classificatórios) propostos, o resumo de suas avaliações está mostrado na Tabela 5.3 a seguir da próxima página. Pode ser observado que das oito, apenas uma alternativa de geração é do tipo não-renovável, Gerador a dísel. Todas as oito alternativas se adequaram aos critérios eliminatórios propostos na metodologia, sendo consideradas aptas a concorrer entre si.

A comunidade isolada pensada para receber esta geração é baseada na comunidade isolada Complexo de Pesquisas Canguçu retirada de Severino, 2008.

Tabela 5.3 - Resumo da avaliação dada às oito alternativas de geração quanto aos critérios.

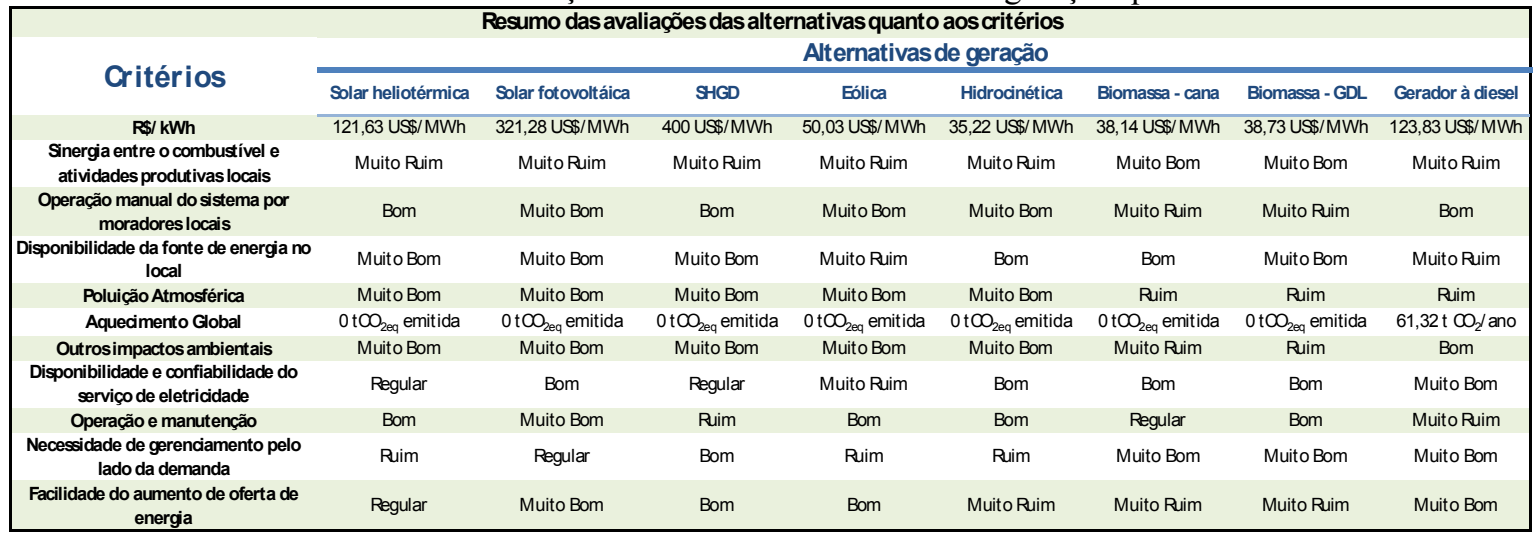

\subsubsection{ELEGENDO PRIORIDADES DOS ONZE CRITÉRIOS}

Como já explicado, o aplicativo oferece duas formas de eleger pesos aos critérios, pelo método Swing e pelo AHP. Para avaliar as oito alternativas de geração, os dois métodos foram testados. Não houve grandes diferenças nas prioridades eleitas pelos métodos Swing ou pelo método AHP, como pode ser visto nas tabelas a seguir. 
Tabela 5.6 - Classificação dos critérios utilizando o método Swing

\begin{tabular}{|c|c|c|}
\hline \multicolumn{3}{|c|}{ Resultado do Método Swing } \\
\hline Oritério & Peso & Prioridade Resultante \\
\hline $\mathrm{R} \$ / \mathrm{kWh}$ & 100 & $31,75 \%$ \\
\hline $\begin{array}{c}\text { Snergia entre o combustivel e atividades } \\
\text { produtivas locais }\end{array}$ & 50 & $15,87 \%$ \\
\hline Disponibilidade da fonte de energia no local & 35 & $11,11 \%$ \\
\hline Operação e manutenção & 35 & $11,11 \%$ \\
\hline $\begin{array}{l}\text { Disponibilidade e } œ \text { nfiabilidade do serviço de } \\
\text { eletricidade }\end{array}$ & 30 & $9,52 \%$ \\
\hline Aquecimento Gobal & 15 & $4,76 \%$ \\
\hline Facilidade do aumento de oferta de energia & 15 & $4,76 \%$ \\
\hline $\begin{array}{l}\text { Operação manual do sistema por moradores } \\
\text { locais }\end{array}$ & 10 & $3,17 \%$ \\
\hline Poluição Atmosférica & 10 & $3,17 \%$ \\
\hline Outros impactos ambientais & 10 & $3,17 \%$ \\
\hline $\begin{array}{l}\text { Necessidade de gerenciamento pelo lado da } \\
\text { demanda }\end{array}$ & 5 & $1,59 \%$ \\
\hline SOMA & 315 & $100,00 \%$ \\
\hline
\end{tabular}

Tabela 5.7 - Classificação dos critérios utilizando o método AHP

\begin{tabular}{|cc|}
\hline \multicolumn{2}{|c|}{ Resultado do Método AHP } \\
Critério & Prioridade Resultante \\
\hline R\$/kWh & $36,88 \%$ \\
Snergia entre o combustível e atividades produtivas locais & $16,17 \%$ \\
Operação e manutenção & $9,09 \%$ \\
Disponibilidade da fonte de energia no local & $8,80 \%$ \\
Disponibilidade e confiabilidade do serviço de eletricidade & $7,77 \%$ \\
Facilidade do aumento de oferta de energia & $7,69 \%$ \\
Aquecimento Global & $4,00 \%$ \\
Poluição Atmosférica & $2,93 \%$ \\
Outros impactos ambientais & $2,56 \%$ \\
Operação manual do sistema por moradores locais & $2,11 \%$ \\
Necessidade de gerenciamento pelo lado da demanda & $2,02 \%$ \\
Soma & $100,00 \%$ \\
\hline
\end{tabular}

A diferença vista entre as duas classificações é de certa forma natural, o que não invalida nenhuma das duas classificações. No entanto, foi observado que eleger as prioridades por meio do método AHP parece dar mais confiabilidade ao resultado, apesar de requerer mais esforço. 


\subsubsection{RESULTADOS DA AVALIAÇÃO DAS OITO ALTERNATIVAS}

Fornecidos os dados e notas parciais, e obtidas as prioridades dos onze critérios, foi possível obter a classificação final das alternativas no aplicativo. Dependendo das prioridades resultantes dos critérios, as notas finais das alternativas e a ordem de classificação tendem a se modificarem.

A classificação final obtida com as prioridades eleitas pelo método AHP, contida na seção anterior, é mostrada na Tabela 5.9. Já a classificação final utilizando o método Swing é mostrada na Tabela 5.11.

Tabela 5.9 - Classificação final utilizando o método AHP

\begin{tabular}{|c|c|}
\hline \multicolumn{2}{|c|}{ Classificação final - método AHP } \\
\hline Alternativa de Geração & Nota final \\
\hline Biomassa - gás de lixo & 7,94 \\
\hline Biomassa - Cana & 7,15 \\
\hline Turbinas Hidrocinéticas & 6,53 \\
\hline Solar Heliotérmico & 5,84 \\
\hline Geração Eólica & 5,50 \\
\hline Solar Fotovoltáico & 4,75 \\
\hline Gerador a dísel & 4,62 \\
\hline SHGD - Sistema Hibrido de Geração Distribuída & 2,92 \\
\hline
\end{tabular}

Tabela 5.11 - Classificação final utilizando o método Swing

\begin{tabular}{|c|c|}
\hline \multicolumn{2}{|c|}{ Classificação final - método Swing } \\
\hline Alternativa de Geração & Nota final \\
\hline Biomassa - gás de lixo & 7,94 \\
\hline Biomassa - Cana & 6,96 \\
\hline Turbinas Hidrocinéticas & 6,54 \\
\hline Solar Heliotérmico & 5,91 \\
\hline Geração Eólica & 5,13 \\
\hline Solar Fotovoltáico & 5,08 \\
\hline Gerador a dísel & 4,13 \\
\hline SHGD - Sistema Hibrido de Geração Distribuída & 3,22 \\
\hline
\end{tabular}

Observe que apesar de serem utilizados métodos distintos para eleger pesos, a ordem de classificação não se alterou e as notas finais tiveram pouca variação. 


\subsubsection{SENSIBILIDADE DOS RESULTADOS AOS PESOS ATRIBUÍDOS AOS CRITÉRIOS}

Por último, será avaliada a sensibilidade do resultado obtido variando-se os pesos dados aos critérios. Observe que as prioridades dos critérios obtidas na seção 5.4.2 podem ser consideradas um pouco conservadoras, por dar mais valor ao critério econômico e menor valor aos critérios ambientais, sendo que os sociais são moderadamente importantes.

Para fins de comparação criou-se uma situação hipotética, onde outro avaliador mais preocupado com questões ambientais e sociais elege as prioridades de acordo com suas preferências, cujo resultado está expresso na tabela 5.7.

Tabela 5.14 - Resultado da prioridades dos critérios com maior peso nos critérios sociais e ambientais.

Resultado - Avaliação ambientalmente e socialmente mais agressivas

\begin{tabular}{|c|c|c|}
\hline Oritério & Peso & Prioridade Resultante \\
\hline $\mathrm{R} \$ / \mathrm{kWh}$ & 100 & $18,02 \%$ \\
\hline $\begin{array}{l}\text { Snergia entre o combustível e atividades produtivas } \\
\text { locais }\end{array}$ & 90 & $16,22 \%$ \\
\hline Aquecimento Global & 70 & $12,61 \%$ \\
\hline Operação e manutenção & 55 & $9,91 \%$ \\
\hline Poluição Atmosférica & 50 & $9,01 \%$ \\
\hline Disponibilidade da fonte de energia no local & 45 & $8,11 \%$ \\
\hline Facilidade do aumento de oferta de energia & 45 & $8,11 \%$ \\
\hline $\begin{array}{c}\text { Disponibilidade e confiabilidade do serviço de } \\
\text { eletricidade }\end{array}$ & 40 & $7,21 \%$ \\
\hline Outros impactos ambientais & 30 & $5,41 \%$ \\
\hline $\begin{array}{l}\text { Necessidade de gerenciamento pelo lado da } \\
\text { demanda } \\
\end{array}$ & 20 & $3,60 \%$ \\
\hline Operação manual do sistema por moradores locais & 10 & $1,80 \%$ \\
\hline SOMA & 555 & $100,00 \%$ \\
\hline
\end{tabular}

De acordo com as prioridades eleitas na tabela 5.7, a classificação das alternativas de geração fica da seguinte forma: 
Tabela 5.15 - Classificação final apos modificadas as prioridades para os critérios

\begin{tabular}{|lc|}
\hline \multicolumn{2}{|c|}{ Classifi cação final } \\
Alternativa de Geração & Nota final \\
\hline Biomassa - gás de lixo & 5,91 \\
Turbinas Hidrocinéticas & 5,63 \\
Solar Heliotérmico & 5,43 \\
Solar Fotovoltáico & 5,42 \\
Biomassa- Cana & 5,03 \\
Geração Eólica & 4,90 \\
SHGD - Sstema Hibrido de Geração Distribuída & 4,16 \\
Gerador à diesel & 3,80 \\
\hline
\end{tabular}

São observadas consideráveis mudanças na ordem da classificação das alternativas, apesar da alternativa 'Biomassa - gás de lixo' continuar sendo a primeira. De forma geral, as alternativas pouco poluentes e que não contribuem para o efeito estufa foram valorizadas nesta análise. A mudança mais significativa de posição ocorreu com a alternativa 'Biomassa - Cana', isto se deve principalmente ao alto grau de impacto atmosférico e outros impactos (exemplo: desmatamento). Já única alternativa com fonte não-renovável caiu para última posição. É possível observar também uma maior equiparação entre as notas das alternativas, comparadas com as classificações anteriores.

\subsection{CONSIDERAÇÕES FINAIS}

Este capítulo apresentou desde os detalhes da utilização do aplicativo, até os resultados gerados por ele. Foi concluída a análise por este aplicativo das oito alternativas de geração, constituindo um exemplo de utilização do programa com objetivo de testá-lo. Desta forma, foi mostrada a funcionalidade do aplicativo multicritério para a análise e comparação de alternativas de geração que envolvam critérios múltiplos aplicados a comunidades isoladas.

Foi possível observar que as prioridades resultantes dos métodos Swing e AHP tendem a não apresentar diferenças significativas entre si. E que apesar de mais demorado, o método AHP tende a transmitir mais segurança ao avaliador quanto às prioridades resultantes dos critérios.

Foi demonstrada a sensibilidade dos resultados à variação das prioridades dos critérios, utilizando prioridades eleitas com inclinação a valorizar mais os aspectos sociais e ambientais, em comparação com a avaliação feita anteriormente. Pôde-se observar a variação na ordem de classificação e nas notas finais das alternativas usadas no exemplo. 


\section{CONCLUSÕES}

Este trabalho abordou, além de outras questões, a problemática do atendimento de energia elétrica a comunidades isoladas e seus aspectos sociais envolvidos. Foi possível observar que, apesar de existirem recursos financeiros dedicados a universalizar o atendimento de energia elétrica no Brasil, as políticas públicas ainda têm tido pouca efetividade no tocante ao fornecimento de energia elétrica a comunidades isoladas. Elas costumam se empenhar na eletrificação rural com a expansão da rede convencional, porém as comunidades muito distantes da rede convencional costumam ficar esquecidas.

Foi discutido que a análise econômico-financeira pura dos projetos de geração ignora os benefícios sociais e ambientais envolvidos na geração de energia elétrica, embora estes benefícios sociais sejam de enorme importância. Como soluções para este problema, foram apresentadas basicamente duas formas de inserir os custos ambientais e sociais conjuntamente com os custos econômicos diretos. A primeira forma apresentada foi a abordagem quantitativa (custos externos) que utiliza métodos de quantificação dos impactos e valoração. Desta forma, esses impactos externos são agrupados nos chamados custos externos, em unidade monetária, que podem ser comparados com os custos econômicos diretos. Sendo assim, os impactos ambientais e sociais, reunidos nos custos externos, podem ser inseridos e levados em consideração, no processo decisório das alternativas de geração de energia elétrica. A segunda forma apresentada para contabilizar os aspectos sociais e ambientais foi a abordagem multicritério. Nela, os diversos aspectos (sociais, econômicos e ambientais) podem ser inseridos, facilmente, na análise por meio dos critérios escolhidos, onde a comparação entre os projetos de geração se dá por meio do valor ou das notas atribuídas aos critérios. Dessa forma, os diferentes aspectos relevantes para a escolha das alternativas de geração podem ser levados em consideração no processo decisório de maneira relativamente simples, independente das dificuldades técnicas em quantificar ou valorar estes aspectos ou impactos inerentes à abordagem quantitativa.

Concluiu-se que a abordagem multicritério é a mais adequada e fácil de incluir aspectos sociais e ambientais na escolha da alternativa de geração. Para tanto, foi criada uma metodologia multicritério que engloba os aspectos ambientais, sociais, econômicos e técnicos na escolha ou classificação das alternativas de geração, aplicadas ao caso 
específico das comunidades isoladas, abordando os pontos considerados relevantes para este caso.

Conjuntamente com a metodologia, foi criado um aplicativo na plataforma Excel $^{\circledR}$ capaz de conduzir a avaliação multicritério das alternativas, buscando facilitar e dar eficiência no processo de análise das alternativas pelos avaliadores/especialistas, em que as notas ou valores fornecidos estejam em concordância com suas preferências internas.

O aplicativo foi validado com um exemplo genérico de oito alternativas onde foi possível concluir a aplicabilidade e funcionalidade do aplicativo para comparar e analisar alternativas de geração de forma satisfatória. Foi também testada a sensibilidade dos resultados aos pesos dados aos critérios, cujos resultados tiveram a variação esperada. No entanto, o aplicativo merece ser testado com exemplos de projetos reais de geração que poderiam fornecer resultados mais interessantes, pois o uso de exemplos genéricos não permite uma boa avaliação de alguns critérios propostos.

Para trabalhos futuros sugere-se que a metodologia e o aplicativo sejam melhores testados para possibilitar a melhoria destes dois últimos, em que seja discutida e testada a relevância de cada critério proposto, e verificadas a eficácia e a facilidade da avaliação aqui proposta com o uso do aplicativo por pessoas que não conheçam, a priori, a metodologia e o aplicativo. Outra sugestão futura é organizar a forma de agregação dos dados de cada avaliação num resultado único, para os casos em que haja mais de um questionário (avaliação) respondido. 


\section{REFERÊNCIAS BIBLIOGRÁFICAS}

[1] ABOUT.COM ECONOMICS. Dicionário de economia. Disponível em:

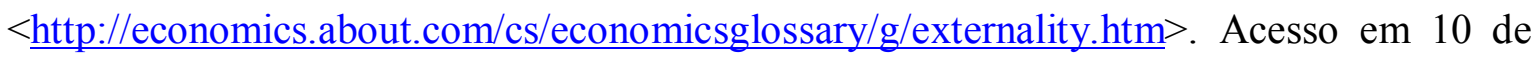
maio de 2008.

[2] BRASIL JUNIOR, Antônio C. P. Energia Renovável para reserva do Maracá. Disponível em: <www.mme.gov.br/download.do?attachmentId=10760\&download $>$. Acesso em: 02 de julho de 2008.

[3] CIPA. Comissão Interna de Prevenção de Acidentes. Página da internet destinada a este assunto. Disponível em < http://www.puc-rio.br/parcerias/cipa/index.html $>$. Acesso em 12 de maio de 2008.

[4] CORREIA, José de Castro. Atendimento Energético a Pequenas Comunidades Isoladas: Barreiras e Possibilidades. T\&C Amazônia, Ano III, Número 6, janeiro de 2005.

[5] EIA. Enviromental Protection Agency, Departament of Energy, U.S. Emissões de dióxido de carbono nos EUA. De Disponível em: $<\underline{\text { http://www.eia.doe.gov/cneaf/electricity/page/co2 report }}>$. Acesso em 25 de maio de 2008 .

[6] EXTERNE, Externalities of Energy. Pagina oficial na internet. Disponível em: $<$ http://www.externe.info/expolwp4.pdf $>$. Acesso em: 12 de maio de 2008.

[7] , Externalities of Energy. Metodology 2005 Update. Stuttgard, 2005. Metodology Update 2005.

[8] EXTERNE-POL. Externalities of Energy: Extension of Accounting Framework and Policy Applications. Multicriteria Analysis. Atenas, 2004. Multicritéria Analysis. : Editora, volume, Disponível em: < http://www.externe.info/expolwp4.pdf $>$. Acesso em: 12 de maio de 2008 .

[9] FERREIRA, M. J. G \& ANDRADE, A. M. Modelagem de Politicas Públicas para Atendimento Energético a Comunidades Isoladas. Anais do $4^{\mathrm{o}}$ AGRENER-2002, Campinas/SP, out/2002. Disponível em: < 